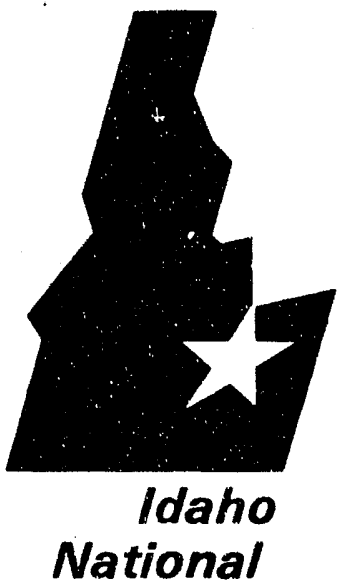

Engineering

Laboratory

Managed

by the U.S.

Department

of Energy
EGG-WTD-10380

August 1992

\section{Chlorinated Solvent Replacements Recycle/Recovery Review Report}

\author{
Monica Beal \\ Daniel Hsu \\ Richard E. McAtee \\ Jerry R. Weidner \\ Lloyd Berg \\ F. Phil McCandless \\ Scott Waltari \\ Charmin Peterson
}




\section{DISCLAIMER}

This report was prepared as an account of work sponsored by an agency of the United States Government. Neither the United States Govemment nor any agency thereot, nor any of their employees, makes any warranty, express or implied, of assumes any legal liability or responsibility for the accuracy, completeness, or usefulness of any information, apparatus, product or process disclosed, or represents that its use would not intringe privateły owned rights. Reterences herein to any specitic commercial product, process, or service by trade name, trademark, manufacturer, or othenwise, does not necessarily constitute or imply its endorsement, recommendation, or favoring by the United States Govemment or any agency thereot. The views and opinions of authors expressed herein do not necessarily state or reflect those of the United States Government or any agency thereot. 


\title{
Chlorinated Solvent Replacements Recycle/Recovery Review Report
}

\author{
Monica Beal \\ Daniel Hsu \\ Richard E. McAtee \\ Jerry R. Weidner \\ Lloyd Berga \\ F. Phil McCandless ${ }^{a}$ \\ Scott Waltari ${ }^{\mathrm{a}}$ \\ Charmin Peterson $^{a}$
}

Published August 1992

\author{
Idaho National Engineering Laboratory \\ EG\&G Idaho, Inc. \\ Idaho Falls, Idaho 83415
}

Prepared for the

U.S. Department of Energy

Office of Environmental Restoration and Waste Management

Under DOE Idaho Field Office

Contract DE-AC07-76ID01570

a. Montana State University, Department of Chemical Engineering, Bozeman, Montana 59717-0392. 


\section{Chlorinated Solvent Replacements Recycle/Recovery Review Report}

EGG-WTD-10380

Prepared by:

Jerry R. Weigher

$x, y,-c i l u c i$

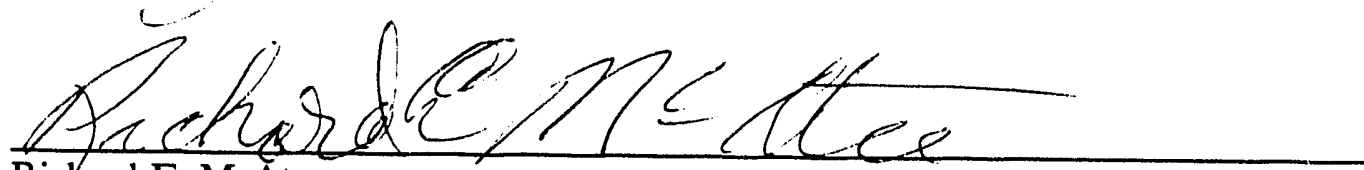

Richard E. McÂtee

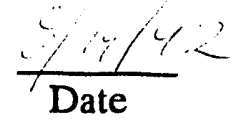

$\frac{8 / 19 / 92}{\text { Date }}$

Approved by:
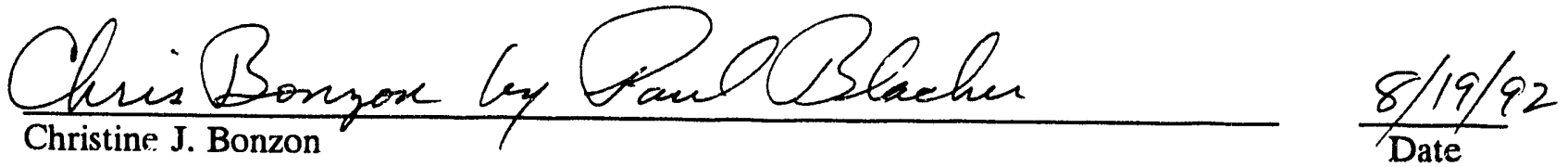


\begin{abstract}
This report is a literature review of waste solvents recycle/recovery methods and shows the results of solvent separations using membrane and distillation technologies. The experimental solvent recovery methods were conducted on solvent replacements for chlorinated solvents at Montana State University. The literature review covers waste solvents separation using distillation, membranes decantation, filtration, carbon adsorption, solvent extraction, and other vapor-phase separation techniques. The results of this study identify solvent distillation methods as the most common separation technique. The alternative separation methods typically supplement distillation. The study shows the need for industries to identify waste solvent disposal methods and investigate the economics of waste solvent recycling as a possible waste reduction method.
\end{abstract}




\section{CONTENTS}

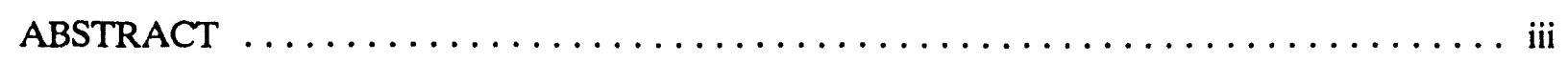

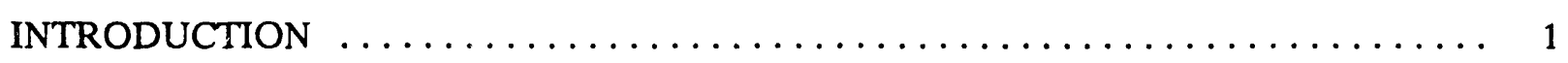

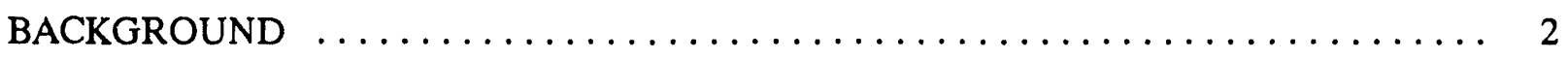

DISTILLATION, THEORY AND PROCESS $\ldots \ldots \ldots \ldots \ldots \ldots \ldots \ldots \ldots \ldots$

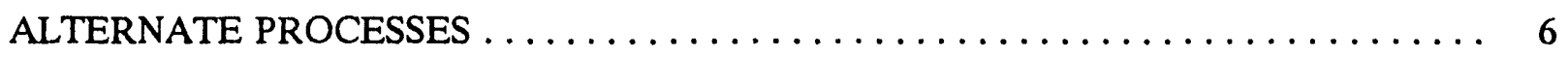

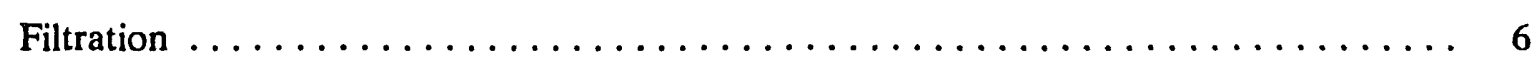

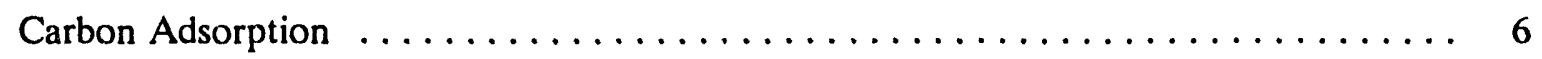

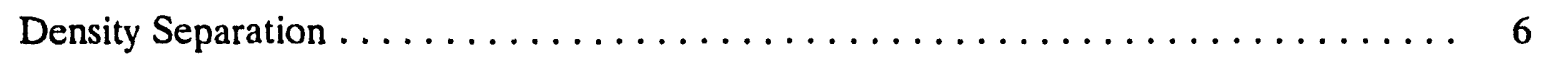

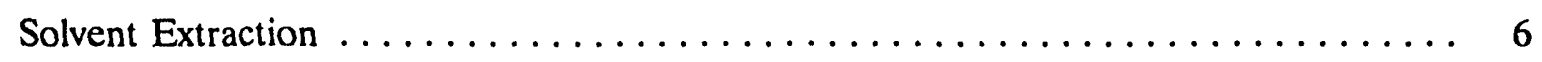

ECONOMIC ASPECTS $\ldots \ldots \ldots \ldots \ldots \ldots \ldots \ldots \ldots \ldots \ldots \ldots \ldots \ldots \ldots \ldots \ldots \ldots \ldots \ldots$

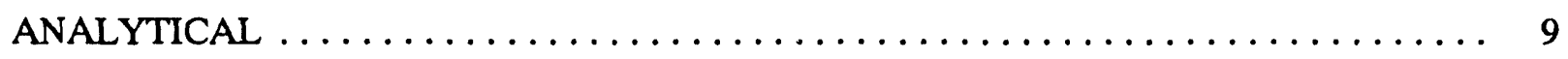

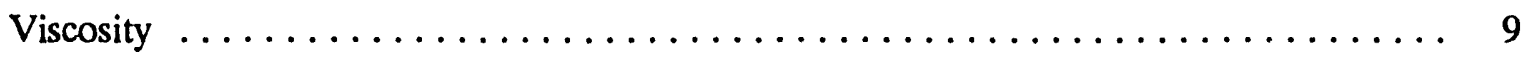

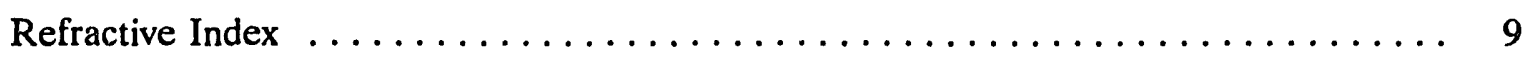

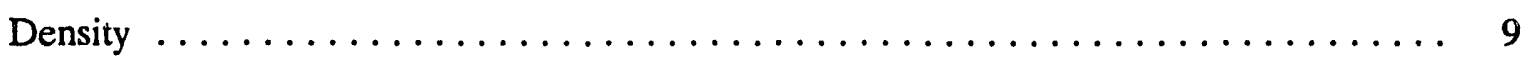

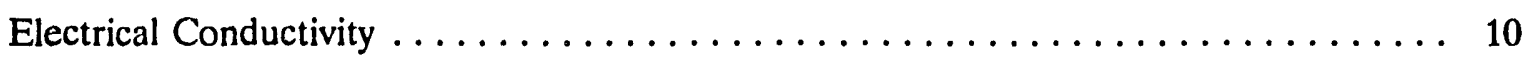

Visible Absorbance Spectroscopy $\ldots \ldots \ldots \ldots \ldots \ldots \ldots \ldots \ldots \ldots \ldots \ldots \ldots$

EXPERIMENTAL DISTILLATION STUDY $\ldots \ldots \ldots \ldots \ldots \ldots \ldots \ldots \ldots \ldots \ldots \ldots \ldots$

DEFOAMING AGENT STUDY $\ldots \ldots \ldots \ldots \ldots \ldots \ldots \ldots \ldots \ldots \ldots \ldots \ldots \ldots \ldots \ldots \ldots \ldots$

SOLVENT DISTILLATION PROCEDURES AND RESULTS $\ldots \ldots \ldots \ldots \ldots \ldots \ldots$

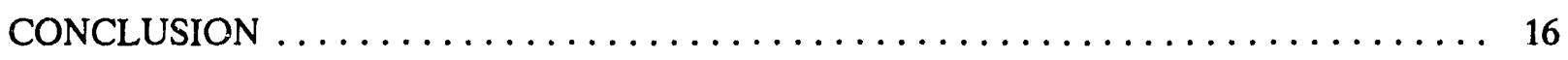

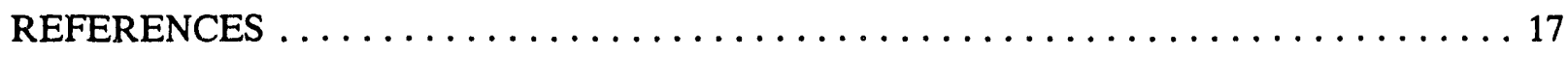

Appendix A-Solvent Recycle/Recovery Subtask FY-91 Summary Report ........... A-1

Appendix B-Membrane Process for Solvent Recycle $\ldots \ldots \ldots \ldots \ldots \ldots \ldots \ldots \ldots$ B-1 
Appendix C-Recovery of Waste Solvents by Rectification, Azeotropic and/or

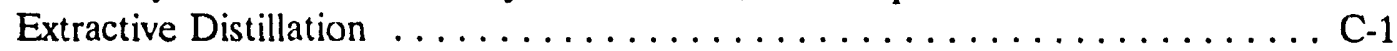

Appendix D-Economic Analysis of 1 Plant Versus 5 Plants $\ldots \ldots \ldots \ldots \ldots \ldots \ldots \ldots$ D-1

Appendix E-5 Plant to 1 Plant Paint Solvent Recovery of TURCO T-5688 Solvent $\ldots . .$. E-1

Appendix F-Solvent Components Boiling Temperatures $\ldots \ldots \ldots \ldots \ldots \ldots \ldots \ldots \ldots$ F-1

\section{TABLES}

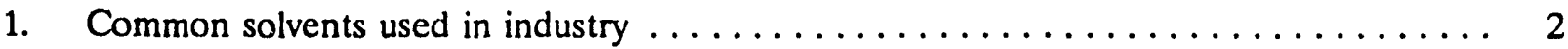

2. Test criteria for used solvents $\ldots \ldots \ldots \ldots \ldots \ldots \ldots \ldots \ldots \ldots \ldots \ldots \ldots \ldots \ldots$

3. Defoaming agents investigated by MSU $\ldots \ldots \ldots \ldots \ldots \ldots \ldots \ldots \ldots \ldots \ldots$

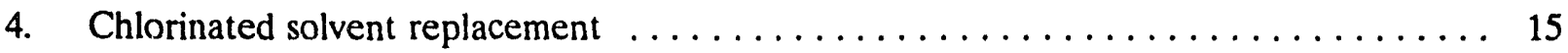




\section{Chlorinated Solvent Replacements Recycle/Recovery Review Report}

\section{INTRODUCTION}

The objective of this study is to review the literature for solvent recycle and recovery technologies in current use by industry, study the recovery of the nonchlorinated replacement solvents for chlorinated solvents using distillation and membrane separation techniques, and evaluate these processes and their economics. Solvent recycling has been practiced by a few industries for over 30 years. For example, dry cleaning has recycled solvent waste using distillation to remove the solvent from its impurities. The oil embargo of 1973, which caused a sharp increase in solvent costs, and the U.S. Congress passage of the Resource Conservation and Recovery Act (RCRA) regulations for waste disposal in the 1980 s has made solvent recycling more economically feasible to many other solvent-using industries and government agencies.

These changes also brought about investigation into the methods of solvent recovery and development of the methods to meet the specific needs of industries and government agencies. This report includes a review of techniques of solvent recovery in current use.

The review covered in the distillation processes have been developed for site-specific needs and economic operation. Other innovative separation processes and predistillation techniques are part of the review. A brief review of the FY-91 studies is reported by Dan Hsu, in Appendix A. Also, the distillation and membrane research studies conducted at Montana State University (MSU) at Bozeman, Montana, are reported. These studies included the reports "Membrane Process for Solvent Recycle" by Dr. F. P. McCandless (see Appendix B), "Recovery of Waste Solvents by Rectification, Azeotropic and/or Extractive Distillation" by Dr. Lloyd Berg (see Appendix C), "Economic Analysis of 1 Plant Versus 5 Plants" by Charmin Peterson (see Appendix D), and "5 Plant to 1 Plant Paint Solvent Recovery of TURCO T-5668 Solvent" by Scott Waltari (see Appendix E). The distillation studies at MSU were conducted with the "new" solvents developed to replace the chlorinated solvents in current use. A study of defoaming agents was a part of the MSU distillation study, which is part of the text of this report. 


\section{BACKGROUND}

Waste solvent recycle recovery processes, though practiced by some industries for more than 30 years, represent less than $12 \%$ of the total solvent waste generated in the United States in $1981 .^{1}$ Even though it is estimated that solvent recycle has increased at about $5 \%$ per year, less than $21 \%$ are being recovered currently. Almost 4.0 billion gallons of solvent waste, of which 1.6 billion gallons are classified as hazardous waste according the RCRA classification, were generated in this country this year (see Reference 1). These hazardous solvent wastes must be either recycled, destructively treated, replaced by nonhazardous solvents, or treated by removal of the hazardous constituents.

The United States has more than 450,000 cold cleaning operations using Stoddard-type solvents (petroleum distillates), 25,000 degreasing operations using halogenated solvents (mostly Freons), and an undetermined amount of metal finishing operations using isopropyl alcohol (IPA). These solvents and groups of solvents represent $23 \%$ of the solvents used in this country. ${ }^{2}$ Other solvents used in industrial applications are listed in Table 1.

Table 1. Common solvents used in industry.

Halogenated Solvents

Dichloromethane

Carbontetrachloride

Chloroform

Tetrachloroethylene

1,1,1-Trichloroethane ${ }^{b}$

Freon ${ }^{b}$

Trichloroethylene

Tetrachloroethane ${ }^{b}$

Petroleum Solvents

Kerosene C

Aliphatic Naphtha

Stoddard $^{\mathrm{b}}$

Toluene

Xylene
Ketones

Acetone

Methyl Ethyl Ketone

Methyl Isobutyl Ketone

Alcohols

Methanol

Ethanol

Isopropanol $^{b}$

Esters

n-Butyl Acetate

Ethyl Acetate

a. This table is only a partial list of solvents used in industry, but represents the solvents most conımonly used.

b. Major Volume Solvents. 
In 1978 , over $80 \%$ of the solvent recovery operations were found in the following industries: solvent refining, polymer synthesis and applications, vegetable oil products manufacturing, metallurgical processes, pharmaceutical manufacturers, cleaning operations, and outside solvent recovery operations. ${ }^{3}$ Solvent refining operations were the major contributor to this effort by reclaiming $72 \%$ of the solvents recycled at that time. In 1984, Congress amended RCRA to restrict land disposal of many hazardous wastes. Most industrial organic solvents are classified hazardous by the RCRA criteria for hazardous materials. This restriction on landfill disposal of most solvent waste forced the industries to look for alternatives for hazardous waste disposal. These alternatives included recycle/recovery and chemical destruction methods (incineration, wet oxidation, etc.). Also, the Environmental Protection Agency's (EPA's) cradle-to-grave regulatory requirements for hazardous waste generators (lifetime responsibility for the generators) requires decisions concerning whether to treat hazardous materials onsite or face increased liability by sending the waste to an offsite treatment facility. This motivated many solvent users to consider onsite recycling processes. Good waste management practices require investigation into the economics of these processes. This report is, in part, a review of the separation technologies in current use for solvent recovery. 


\section{DISTILLATION, THEORY AND PROCESS}

Congress enacted the RCRA legislation to deal with the increasing concern of hazardous waste treatment, storage, and disposal. The act deals with all types of waste, of which a large portion are organic solvents. In the past, solvent wastes were disposed of in landfills. This practice is no longer acceptable under RCRA regulation. Two alternatives to landfill disposal are incineration and reclamation. Currently, many industries are recycling their spent solvents due to the increasing costs of new solvents and the costs of spent solvent disposal. Distillation and other vapor phase separation techniques have been the most common methods of purifying the solvents for reclamation. Distillation process equipment has undergone more innovative development to meet a variety of industrial site-specific needs. This section discusses the distillation processes and equipment.

Typically, simple distillation is used in single solvent waste to evaporate and condense the solvent away from its impurities. Distillation uses a batch or continuous feed system in which the heat is applied external to the system or steam can be directly injected into the solvent waste to volatilize the solvent away from its impurities. ${ }^{4}$ Simple distillation is used, as stated before, for single solvents. It is also possible to separate two and three component solvent waste with simple distillation if the differences in vaporization temperatures of the solvents is great enough and azeotropes are not formed. For example, water (boiling point $100^{\circ} \mathrm{C}$ ) and ethanol (boiling point $78.5^{\circ} \mathrm{C}$ ) mixtures can be separated by this method. However, the ethanol purity will be something less than $95 \%$, as the azeotrope formed between ethanol and water is $95 \%$ and $5 \%$, respectively. To separate this azeotrophic mixture requires adding an entrainer, such as benzene, to the mixture and using a fractional distillation column with pressure control (vacuum and pressure).

Typically, multi-component solvent waste requires a fractional distillation column. These columns have trays or packing to improve column vapor-liquid interface. Other column controls include the reflux rates, temperature control, pressure and vacuum control, packing/tray design, and column diameter and height. In addition, the distillation process may require two or more distillation column units.

Distillation unit selection is dependent on the solvent purity requirements. Industries using high purity solvents in their processes require a more complex distillation and pretreatment system. However, many industries using solvents for cleaning processes or using recovered solvents as a fuel supplement require the reclaimed solvents be less pure. In these industries, simple distillation of the solvent waste is adequate.

Because of the variety of industries considering solvent recycle in their hazardous waste reduction efforts, innovation in solvent reclamation methods have developed equipment and processes specific to their needs. Small distillation units for point source solvent recycling have been developed. ${ }^{5}$ Also, industries preferring onsite treatment, but whose reclamation needs do not justify the capital costs required in building a distillation unit, have the option of having a mobile distillation unit ${ }^{6,7}$ moved to their facilities for solvent recovery. Also, the mobile distillation unit is advantageous to a company having solvent use facilities that are not centrally located.

Although there are other methods of solvent recovery, such as thin-film rotary evaporators (vapor phase separation), solvent extraction, steam stripping, carbon adsorption, and super critical fluid extraction, these methods are generally used as a pretreatment to distillation. ${ }^{8}$ 
Because the distillation process is energy intensive, energy costs can be reduced using multieffect or mechanical recompression, or an incinerator and waste heat recovery system in which the still bottoms are used in the incinerator. ${ }^{9}$ There are many other energy saving modifications for the distillation process and with increasing energy costs many more innovative energy reduction methods and apparatus will be developed. 


\section{ALTERNATE PROCESSES}

The distillation processes, which include all the solvent recovery techniques based on liquid-gas phase separation, are the primary methods used for solvent recovery. However, other processes are effectively used to supplement distillation, generally as pretreatment steps in waste processing. Typically, the output streams of the alternate processes serve as feed stock for two or more other applications. For example, one product stream is used as fuel and a second is processed by distillation. ${ }^{10}$ Usually, this produces at least one out-put stream which is distilled. In certain circumstances, the output stream is sufficiently pure for direct re-use without further purification. ${ }^{11}$ The alternate techniques include filtration, carbon adsorption, density separation (centrifuge and decantation), solvent extraction, and process systems designed for special applications (see Reference 1).

\section{Filtration}

Filtration is a pretreatment step used in virtually all solvent recovery processes to remove particulate matter. An example is the specialized ultrafilters used in conjunction with self-cleaning centrifuges to effectively process oil waste. ${ }^{12}$

\section{Carbon Adsorption}

Carbon adsorption is the principle process used to remove gasenus materials, mainly organic, from industrial ventilation and fume hood off-gas systems. ${ }^{11,13,14}$ In general, the process directs solvent laden air into beds of activated charcoal. The solvents are absorbed onto the activated charcoal until the charcoal becomes saturated with solvent. The charcoal is reactivated by a steam distillation process which removes the solvent from the charcoal. The solvent is usually recovered from the spent steam by density separation and/or distillation (see Reference 11).

\section{Density Separation}

Density separation includes two related processes, decantation and centrifuge, which use the density difference among the phases present in order to affect phase separation. The decantation process is usually applied to systems containing two (or more) phases, usually immiscible liquids such as oil and water which have a different density. The denser liquid settles to the bottom of the container while the less dense liquid floats on the top. The two phases are then separated by simple decantation. ${ }^{11,15,16}$ The two fractions usually receive additional processing (see Reference 16). Density separation using a centrifuge rather than simple gravity settling is more effective and faster in separating the immiscible phases of different densities, but is more expensive (see Reference 12).

\section{Solvent Extraction}

Solvent extraction includes those processes which use the addition of a suitable solvent to the system to dissolve the material to be recovered. The solvent is typically a solvent which is immiscible with the host liquid. The material to be recovered preferentially concentrates in the extraction solvent, which is then removed by some method such as decantation. The solvent is then processed, usually by distillation, to remove the material to be recycled and the solvent is reused. ${ }^{16,17}$ 
The typical application of solvent recovery processes does not rely on a single method, but uses a combination of procedures to optimize the efficiency of each. This is illustrated by considering the B.E.S.T. process as an example (see Reference 16). The B.E.S.T. process is a solvent extraction system designed to treat oil-contaminated waste, but it uses several types of procedures to remove the oil. Triethylamine is used as the extraction solvent. At temperatures below $20^{\circ} \mathrm{C}$ the triethylamine is miscible with water and organic liquids, such as petroleum. Solid contaminates are separated using a density separation. At temperatures $>20^{\circ} \mathrm{C}$, the water and triethylamine are immiscible and the petroleum compounds are more soluble in the triethylamine phase. The two liquid phases are separated by gravity, i.e., decantation. The final step is solvent recovery from each of the two liquid streams. The water stream is cleaned to $<50 \mathrm{ppm}$ triethylamine/petroleum compounds by "conventional air stripping." The triethylamine is recovered from the petroleum compounds by distillation (see Reference 16). 


\section{ECONOMIC ASPECTS}

The increasing costs of energy and raw materials have drawn attention to the use and/or recovery of solvent by-products from manufacturing processes, which were once considered not economically feasible to recover. However, in some industries the sale or reuse of recovered solvents contributes a significant amount to the profitability of their operations. The increasingly stringent federal, state, and local requirements controlling waste emissions and traditional waste disposal practices, e.g., in contiolled landfills, have further increased the incentive for solvent recovery and reuse. For example, a study of six Naval Air Rework Facilities (NARF) indicates that 1,103,000 gallons of solvent are not being reclaimed. Reclaiming six of the solvents with the largest volumes represents $87 \%$ of the total solvent waste. To replace the major used solvents costs $\$ 1,088,000$. To reclaim these six solvents, allowing for a $20 \%$ loss in processing, saves the six NARF's $\$ 870,000$ in the cost for new solvents and the elimination of the disposal costs for these six solvents of $\$ 757,000$ per year ( $87 \%$ of the estimated costs of $\$ 870,000$ per year for solvent waste disposal). This does not take into account the capital and operational costs for reclamation process equipment. However, the reclamation costs at "out of house" recovery is approximately $\$ 670,000$ at an average cost of $\$ 0.70$ per gallon. This shows a savings of $\$ 957,000$ for reclaiming the six solvents. ${ }^{18}$

Many variables control the feasibility of solvent recovery and the type of system used. Clearly, important factors include regulatory requirements, equipment costs, personnel training costs, available treatment technologies, and waste properties such as composition, concertration, viscosity, vapor pressure, etc. Feasibility is also affected by recovery objectives. A possible objective is the reuse of the recovered solvent in the original application. It may be that the specifications of the recovered material do not meet the requirements of the original application. If so, then the recovered material may be sold or used for another application within the plant. Where direct solvent recovery is not economically feasible, the energy content of the waste may be recovered by incineration in industrial or specially-designed boilers. Each recovery application requires a detailed review to ensure that the system chosen is the most efficient available. Factors to be considered in an economic evaluation of a solvent recovery system include waste properties, treatment objectives, regulatory requirements, personnel training costs, and available treatment technologies. ${ }^{19-22}$ 


\section{ANALYTICAL}

Even when the spent solvents are recovered, a great deal of waste can occur if the spent solvent is sent for recovery before it is fully used. To maximize the use of the original solvent, guidelines must be developed to determine when a solvent should be processed and recycled. These tests are relative and must be developed further for each different type of solvent application. In addition, there is no single analytical method which can be used to evaluate when a solvent is fully spent. A variety of analytical methods are more effective in evaluating a solvent conditica allowing a more efficient use of the original solvent.

There are seven different measurements that have been explored as possible characterization tests for spent solvents (see References 2 and 23). These measurements include:

- Kauri-Butanol Values

- Viscosity

- Refractive Index

- Density

- Electrical Conductivity

- Visible Absorbance Spectroscopy

- Thin Layer Chromatography.

Each of these processes was evaluated based upon sensitivity and reliability, reproducibility, ease of operation, operator iraining, equipment costs, and maintenance costs. Based upon these criteria, five processes were selected às the best available tests. Each of these tests is discussed.

\section{Viscosity}

This measurement is easily made in the laboratory and is reproducible, requires minimal training for the technician, equipment costs are under $\$ 500$, and the annual maintenance costs are minimal. The only drawback with this test is that it is temperature dependent. Therefore, close attention is necessary to ensure that all samples are tested at the same temperature for an accurate measurement.

\section{Refractive Index}

This measurement is easily reproducible in the laboratory, is easy to operate, requires minimal operator training, and has a low annual maintenance cost. The only drawback with this process is that it is not sensitive to halogenated material in the spent solvents. It is sensitive for most all other solvents.

\section{Density}

This measurement is easily reproducible in the laboratory, is easy to operate, requires minimal operator training, and has low annual maintenance cost. It does require close attention to volume and weight measurements. 


\section{Electrical Conductivity}

This measurement is easily reproducible in the laboratory, is easy to operate, and requires minimal operator craining. The drawback with this measurement is high maintenance on the conductivity probe which requires frequent replacement.

\section{Visible Absorbance Spectroscopy}

This measurement is very sensitive and reliable, is easily reproduced in the laboratory, requires minimal technician training, and has minimal annual maintenance costs. Of all the processes this is the best single measurement. An optical probe colorimeter can be dipped directly into the solvent vat to give an instantaneous readout.

A set of guidelines have been developer in which all of the discussed measurements are used collectively to determine whether or not a soivent is spent (see Reference 23).

- Measure the absorbance with an optical probe colorimeter or a hand-held spectrometer placed directly into a vat or container to obtain an instantaneous readout of visible absorbance (at $500 \mathrm{~nm}$ ). Assign a rating (0 to 2) based on Table 2.

- Measure the density using an electronic meter or pycnometer. Assign a rating (10 to 3 ) based on Table 2.

- Measure the viscosity using an Ostwald viscometer. Assign a rating (0 to 2$)$ based on Table 2.

- Measure the electrical conductivity with a conductivity meter. Assign a range (lo to 1$)$ based on Table 2 .

- Sum the individual rating in steps 1 through 4 to obtain an overall rating for the solvent.

- If the cutoff rating is greater than or equal to six, the solvent can be considered spent and is a candidate for reclamation. Solvents with a rating of less than six should be kept in service.

As stated, the values in Table 2 are guidelines developed for one specific solvent recovery process. Values must be determined for each individual process. 
Table 2. Test criteria for used solvents (see Reference 23).

\begin{tabular}{ccccc}
\hline Rating & $\begin{array}{c}\text { Absorbance } \\
(500 \mathrm{~nm})\end{array}$ & $\begin{array}{c}\text { Density } \\
\left.17^{\circ} \mathrm{C}\right)\end{array}$ & $\begin{array}{c}\text { Viscosity } \\
\mathrm{cp}\left(18^{\circ} \mathrm{C}\right)\end{array}$ & $\begin{array}{r}\text { Conductivity } \\
\text { nmbo }\left(23^{\circ} \mathrm{C}\right)\end{array}$ \\
\hline 0 & $<0.6$ & $<0.773$ & $<1.35$ & $<22.5$ \\
1 & $0.6-0.8$ & $0.773-0.779$ & $1.35-1.85$ & $>22.5$ \\
2 & $0.8-1.0$ & $0.779-0.785$ & $>1.85$ & - \\
3 & $1.0-1.2$ & $>0.785$ & - & - \\
4 & $>1.2$ & - & - & - \\
\hline
\end{tabular}




\section{EXPERIMENTAL DISTILLATION STUDY}

Distillation studies of replacement solvents for chlorinated solvents were conducted at Montana State University, Bozeman, Montana, by the Chemical Engineering Department. Thirteen solvents were studied in FY-92. These solvents were selected from the Chlorinated Solvent Replacement Program for their performance as solvents and minimum corrosion effects. It was assumed that the solvents be used in clean up after a paint stripping operation. To simulate this, the solvents refluxed in paint chips were obtained from a paint stripping facility at Kelly Air Force Base, San Antonio, Texas. Also, it was assumed that the solvents would be used in metal cleaning processes where grease, oil, and wax would be part of the residual material on the metal surfaces. To simulate this, two solvents, Orange-Sol De-Solv-It and EXXON EXXATE 1000, were loaded with wax (Petrolite BE SQUARE 175) to simulate the effect of metal cleaning on the solvents. In the wax-loaded solvents a problem arose with foaming in the distillation column. This resulted in a study of defoaming agents. Twenty nine defoaming agents were obtained from 11 vendors. The results of the study are discussed in the following section. Also the distillation study and results are shown in Appendix F. 


\section{DEFOAMING AGENT STUDY}

During the distillation study, some of the solvents caused foaming in the distilation column. This was especially true in the solvents loaded with wax. This initiated a study of defoaming agents. Table 3 lists the defoaming agents used in the study.

Of the 29 defoaming agen.s studied, only one (Dow Corning 7 Additive) worked in the distillation of the wax-loaded solvents Exxate 1000 and Orange-Sol De-Solv-It. Three defoaming agents worked in the distillation of the solvent Exxate-1000. They were Dow Corning 7 Additive, WITCO BB 3295, and Henkel Dehydran 1628.

Table 3. Defoaming agents investigated by MSU. ${ }^{a}$

Air Products Surfynol DF-1100

" " DF-58

“ “ XF-B4152

Witco BB 3295

a BB 3056A

“ BB 7762

EXXON COREXIT 362

" Surflo AF 2436

Surflo AF 8574

" “ AF 7669

PPG MAZU DF-200-EX

" MACOL 5100

“ MAZTREAT 246

AKZO Propomeen T-25

Genesee Polymers DB-12
Henkel Dehydran 1628

" " 1208

" " 1293

" " 1513

" ARA-7219

“ Perenol S-43

" " E-2

" " E-3

Union Carbide SAG 47

" "SAG 1000

BASF Pluronic L-31

“ " 25 R-2

Hercules Defoamer 831

Dow Cornirig 7 Additive

a. Personal correspondence from L. Berg, Montana State University, to R. E. McAtee, EG\&G Idaho, Inc., June 21, 1992. 


\section{SOLVENT DISTILLATION PROCEDURES AND RESULTS ${ }^{24}$}

1. Prepare a mixture of 450 grams of the solvent and 50 grams of paint chips. Stir this mixture at the solvent manufacture's suggested operating temperature for approximately 48 hours.

2. For the samples refluxed in paint chips, use a $11.0 \mu \mathrm{M}$ filter in the prefiltering step and a $0.7 \mu \mathrm{M}$ filter as the final filter. After filtering, if the solvent is in two phases, separate by decantation befcre distillation.

3. Do not filter the wax-loaded samples.

4. Rectify liquid samples in batch mode in rectification column. Have 8. 15, and 30 theoretical plate helices packed columns available. Record and plot data as temperature of overhead vs. percent of charge distilled. This will indicate the quality and boiling point of each constituent.

5. Repeat rectification and collect samples of the pure material as they come off. Check purity on the Alltech RSL 300 gas chromatograph and Spectra-Physics Chrom-Jet integrator.

6. Knowing the several compounds in the mixture, determine the relative volatility in the other type vapor-liquid equilibrium still between each adjacent pair.

7. On the adjacent pairs from \#5, if the relative volatility is above 1.4 , demonstrate separation in the rectification column of known theoretical plates to determine precisely the true relative volatility.

8. Identify from all the samples received which can be separated by straight rectification and which will require more intensive separation methods, such as azeotropic or extractive distillation.

The solvents used in the above distillation study by Montana State University are listed in Table 4. 
Table 4. Chlorinated solvent replacement.

$\underline{\text { Manufacture }}$

Ambion Corp

Specialty Prod.

Orange-Sol

Petroferm Corp.

Colloid Prod.

Harry Miller Corp.

Exxon

Arco Chemical Co.

Vista

Boeing

GAF
Solvent

Hotstrip

SP-828

De-Solv-It

Bioact VS-5

RBD SEMI

Citriterge 8910

Exxate 1000

Acrosolv-TMP

LPA-210

MOK

MOK 2437

Ship Shape

n-methylpyrrolidene 


\section{CONCLUSION}

This report is a review of the literature on current and past solvent recycling efforts by industry in this country. It shows that only about $20 \%$ of the solvent waste is being recycled. Several articles discuss the economics of recycling and how specific industrial processes have greatly reduced their hazardous waste output and their costs for new solvents. Even when the recycled solvents are of a purity that cannot be reused in the original applications, it is marketable to other industries or can be used as a fuel substitute. In general, recycling solvents reduces the amount and cost of solvent waste disposal.

This study shows that the distillation process is still the primary solvent recycling method. Because it is energy intensive, there has been much effort to reduce the energy requrements through innovative design and pretreatment. Analytical methods have been studied to determine the life cycle of a solvent so it can be used to maximum efficiency. These innovations contribute to the reduction of solvent waste.

The distillation study at Montana State University has shown that many of the replacement solvents for chlorinated solvents can be recovered for reuse. The percentage of recovery of these solvents is comparable to that of other solvent distillation processes. Finally, the data collected in this study will be entered into the Solvent Handbook. 


\section{REFERENCES}

1. B. L. B'aney, "Alternative Techniques for Managing Solvent Wastes," Journal of the Air Pollution Control Association, Vol 36, No 3, March 1986.

2. J. B. Suendax et al., "Methods for Monitoring Solvent Condition and Maximizing Solvent Utilization," Proceedings of the 5th National Conference on Hazardous Waste and Hazardous Materials, Las Vegas, Nevada, April 19-21, 1988, p. 102.

3. D. R. Tierrey and T. W. Hughs, EPA 600/2-78-6048, April 1978.

4. D. R. Tierrey and T. W. Hughs, Source Assessment, Reclaiming of Waste Solvents, State of the Art, EPA 60012-78-004F, April 1978.

5. "On-Site Solvent Recovery." American Machinist and Automated Manufacturing, May 1987, p. 75.

6. T. C. Keener and E. J. Shoemaker, "Mobil Solvent Recovery from Industrial Hazardous Wastes," 80th Annual Meeting of the APCA, New York, NY, June 21-26, 1987.

7. T. C. Keener, "Recovery of Solvents from Industrial Hazardous Waste Via Mobile Recovery System," R. Abbou, ed., Hazardous Waste Detection, Contrcl, Treatment, Elsevier Science Publishers, Amsterdam, 1988.

8. R. A. Ollexey et al., Hazardous Waste and Hazardous Materials, Vol 5, No 4, 1988, Mary Ann Liebert, Inc., Publishers.

9. H. Shinozak, "Methods of Recycling Used Solvents," Conservation and Recycling, Vol 10, No 4, 1987, p. 243.

10. D. K. Jackson, W. Brown, K. D. Burrel, and I. R. McGregor, Development of a System to Combine Solvent Recovery with the Recovery of Heat From Residual Organic Wastes, Report EPS 3/Cl/1 for the Technology Development and Technical Services Branch, June 1989.

11. W. R. Meyer, Solvent Broke, Vulcan-Cincinnati, Inc., Cincinnati, Ohio, The Engineering Society Library (ESL), New York, NY.

12. A. Gressel, Waste Oils ana Solvents Justify By-Product Recovery Plant, July/August 1982, pp. 23-25.

13. J. A. Hill and E. L. Meyer, "Minimizing Hazardous Waste Through Solvent Recovery, Recycling and Substitution," 20th International SAMPE Technical Conference, September 27-29, 1988, pp. 213-218.

14. S. Treacher, "Recycling: Positive Approach to Used Solvent Handling," Environmental Pollution Management, Vol 3, No 4, 1973, pp. 203-205. 
15. R. W. Caputi, E. G. Pierick, D. V. Brumley, B. Kincaid, Spent Liquid Organic Solvent Recovery System, U.S. Patent 4664754, May 12, 1987.

16. D. A. Austin, "The B.E.S.T. Solvent Extraction Process Resource, Recovery, Waste Minimization, and Treatment in a Single Step Application to RCRA, CERCLA, and TSCA Wastes," National Petroleum Refiners Association Annual Meeting, San Francisco, California, March 19-21, 1989.

17. I. C. Lauer, E. J. Littlewood, J. J. Butler, "Solvent Extraction Process For Phenols Recovery From Coke Plant Aqueous Waste," Eastern States Blast Furnace and Coke Oven Association, Iron and Steel Engineeis, May 1969, pp. 99-102.

18. H. J. Lee, I. H. Custis, W. C. Hallow, A Pollution Abatement Concept, Reclamation of Naval Air Rework Facilities Waste Solvent, Phase-1, Report No. NADC-678028-60, 1978.

19. G. E. Bateman, S. J. Zoss, and G. A. Honenstein, "Organic Solvent Recovery," Industrial Wastes, Nov./Dec. 1982, pp. 8-10.

20. G. E. Tapio, A Limited Test of Solvent Reclamation at an Air Force Flightline Facility, ESL-TR-84-52, 1985.

21. Hsīi-Neng Hsieh and H. Ertdogan, "Cost Estimates for Several Hazardous Wastes Disposal Options," Hazardous Waste and Hazardous Materials, Vol 5, No 4, 1988, pp. 329-342.

22. R. B. DenUyl, N. VanPoperin, D. Whitehill, A. Winter, P. Alsoger, M. Deline, J. Hall, W. McGrath, and R. Strader, Hazardous Waste Management In The Great Lakes Region: Opportunities For Economic Development and Resource Recovery, Report Prepared for National Bureau of Standards, Washington, D.C., Report No. PB83-124693, 1982.

23. B. A. Donahue, A. R. Tarrer, S. Dharmavaram, and S. B. Joshi, Used Solvent Testing and Reclamation, Volume 1: Cold-Cleaning Solvents, AD-A204 731, December 1988.

24. L. Berg, Recovery of Waste Solvents by Rectification, Azeotropic and/or Extractive Distillation, Department of Chemical Engineering Montana State University, 1991. 


\section{Appendix A}

\section{Solvent Recycle/Recovery Subtask FY-91 Summary Report}




\title{
CHLORINATED SOLVENT SUBSTITUTION PROGRAM \\ SOLVENT RECYCLE/RECOVERY SUBTASK \\ SUMMARY OF FY-91 INVESTIGATION
}

\author{
D. Hsu
}

December 1991

\section{SUMMARY}

Distillation and membrane separations tests on recovering non-chlorinated solvents that meet the performance efficiency and corrosion criteria were conducted in the laboratory in FY-91. The results, summarized in this report, show that distillation could be both technically and economically feasible. Membrane separations technology, on the other hand, does not appear promising. As a result, study of distillation is recommended to be continued, but that of membrane separations discontinued.

\section{INTRODUCTION}

As an outgrowth of the Department of Energy (DOE) Chlorinated Solvent Substitution Program, the Solvent Recycle/Recovery Subtask was initiated two years ago in FY-90. The goal was to develop substitute solvent recycle/recovery process(es) so that the use of fresh solvents can be reduced and the generation of spent solvents that need to be disposed can be minimized. Specific objectives of the subtask were: (a) to identify and test available technologies to recover and recycle substitute solvents used in production and maintenance operations and (b) to identify emerging technologies promising for recovering and recycling spent substitute solvents.

Candidate substitute solvents that pass the test criteria, such as paint stripping performance efficiency and corrosion test, examined in separate subtasks under the Chlorinated Solvent Substitution Program, are studied in the solvent recycle/recovery subtask. The first phase of this subtask, conducted in FY-90, consisted of a literature search of solvent recovery technologies and a preliminary distillation study. In the distillation study, fresh substitute solvents were, distilled. The results of the Phase I study have been previously reported.'

As a result of the Phase I literature search, distillation and membrane separations technology were identified to be promising for further investigation. Accordingly, the effort in FY-9l was focused on these two technologies. Laboratory tests using these technologies to recover spent substitute solvents was subcontracted to and conducted at the Department of Chemical Engineering, Montana State University. Professors Lloyd Berg and F. Phil McCandless were responsible for conducting, respectively, the distillation and membrane separations tests. 


\section{SCOPE OF INVESTIGATION}

The scope of investigation for FY-91 for distillation included examining spent and fresh solvents to determine which method should be recommended for solvent recovery application. Possible distillation methods include precision rectification and azeotropic and extractive distillation.

For membrane separations technology, microfiltration, ultrafiltration (UF), and nanofiltration were to be examined to determine the feasibility of using these processes for solvent recovery.

Fresh, spent, and recovered solvents would be analyzed by high pressure liquid chromatography (HPLC) to compare their characteristics. A HPLC system was to be acquired in FY-91 for the analyses.

A total of 15 solvents, including 10 paint stripping solvents and 5 biodegradable cleaning solvents, were originally planiled to be tested'. For various reasons, including candidate substitute solvent not truly commercially available, containing highly toxic ingredients, being aqueous, and showing intolerable corrosion characteristics upon further testing, through the course of the study, the number of solvents was reduced to 9.

\section{RESULTS AND DISCUSSION}

The results of the distillation and membrane separations studies are contained in the two report.s, prepared, respectively, by Professors Berg and McCandless, attached to this summary report. Because of the difficulties incurred in obtaining true spent solvents, tests were conducted on simulated spent solvents. For paint strippers, paint chips obtained from a solid $\mathrm{CO}_{2}$ blasting paint removing demonstration project were dissolved in fresh solvents to generate simulated spent solvents. For biodegradable cleaners, wax was dissolved in fresh solvents to generate simulated spent solvents.

\section{Distillation}

Distillation tests show that it is generally feasible to recover the substitute solvents by distillation. For single-component paint strippers, the recovery procedure is relatively simple-a single-temperature distillation/precision rectification will achieve recovery of the solvents. For multi-component paint strippers, distillation/precision rectification at multiple temperatures is needed. For either single- or multi-component paint strippers, vacuum distillation may be required, depending on the thermal stability of the solvent components.

Although not specified in the scope of work, a couple of sample economic analyses, one of a single-component solvent and the other of a multi-component solvent, were conducted and presented in Berg's report. It shows that, with a hypothetical plant size of $30,000 \mathrm{gal} /$ year, distillation recovery of solvents used for paint stripping would have a payback period of about three months. For a three-component paint stripper, the same plant size would result in a payback period of approximately 13.5 years. However, if one large facility is used to process the same three-componert solvent from five $30,000 \mathrm{gal} /$ year 
operations (e.g., a centrally located solvent recovery plant to process spent solvents from five Air Force Logistic Centers), the payback time would be approximately 7 months.

It should be noted, however, that the economic analyses presented in Berg's report were preliminary in nature. In-depth analyses will be required to further identify the economic feasibility of recovering substitute paint strippers by distillation.

Distillation recovery of biodegradable cleaners is not as straightforward. Tests show that foaming would be a problem and an antifoaming agent would be necessary to break the foam in the distillation column. An appropriate antifoaming agent is being sought at the present time.

\section{Membrane Separations}

Preliminary membrane separations tests show that, using a membrane made of material compatible with the solvent, UF can remove contaminants in the spent solvent. However, two problems appear to exist that will need to be solved before a practical membrane process can be developed for solvent recovery application. First, current commercial membranes are designed primarily for aqueous system applications. A commercial membrane for organic solvent application is yet to be developed. Second, for one membrane (made of cellulose acetate) that is compatible with several substitute solvents tested, the system pressure required to obtain measurable flux was excessive (over 600 psi versus typical UF pressures of less than 100 psi).

\section{HPLC Analysis}

HPLC analysis of fresh, spent, and recovered substitute solvents was planned to be conducted to verify the integrity of the recovered solvents. Unfortunately, because of a series of unexpected analytical difficulties, ranging from setting up of the HPLC system to getting the system to function properiy (involving selecting proper system parameters), no usable results have been generated as of the time of the report. Work is still ongoing in trying to produce the planned analyses.

\section{CONCLUSIONS}

Since the work is still ongoing, only tentative conclusions can be made:

- Both distillation and membrane technologies are technically feasible for recovering substitute solvents after they have become spent

- Because of the excessive system pressure required and because of the challenging task of finding appropriate membranes for use, membrane technology does not appear promising for substitute solvent recycle/recovery at present

- Limited preliminary economic analyses show distillation to be promising for substitute solvent recycle/recovery application; the payback period for investment appears favorable 
- The characteristics of recovered substitute solvents are yet to be determined, pending completion of the HPLC analyses.

\section{RECOMMENDATIONS}

Based on the results obtained thus far, the following recommendations are made:

1. Complete HPLC analysis of fresh, spent, and recovered substitute solvents to verify the integrity of the recovered solvents.

2. Continue searching for an appropriate antifoaming agent for use in distillation recovery of biodegradable cleaners.

3. Discontinue laboratory testing of solvent recycle/recovery by membrane separations.

4. Expand/Refine the economic analysis initiated by Dr. Berg; conduct, to the extent practical, in-depth analysis to better define the economic feasibility of distillation recovery of substitute solvents. If the results are favorable, a pilot plant test program should be considered.

\section{REFERENCES}

1. Paffhausen, M. W., D. L. Smith, and S. N. Ugaki, "Solvent Recycle/Recovery Phase I Final Report," EGG-WTD-9297, September 1990. 


\section{Appendix B}

\section{Membrane Process for Solvent Recycle}




\title{
Chlorinated Solvent Substitution Program \\ Recycle/Recovery Subtask
}

\section{MEMBRANE PROCESS FOR SOLVENT RECYCLE}

\author{
FINAL REPORT \\ CONSULTING AGREEMENT NO. C92-103140, MOD. 1 \\ F. P. MCCANDLESS \\ DEPT. OF CHEMICAL ENNGINEERING \\ MONTANA STATE UNIVERSITY \\ BOZEMAN, MT 59717
}

\section{SUMMARY}

Microparticle filtration followed by ultrafiltration was investigated as a process to recover and recycle non-chlorinated solvents used for paint stripping operations. Spent solvents were simulated by digesting paint ships with hot solvents. These chips were obtained from airplane surfaces by biasting with solid $\mathrm{CO}_{2}$. From about 47 to 80 percent of the paint solids were recovered by MF through filters that reject particles greater than $11 \mu \mathrm{M}$, while another 0.1 to 1.0 percent was recovered with $0.7 \mu \mathrm{M}$ filters. UF through teflon membranes with $0.02 \mu \mathrm{M}$ pores resulted in no further paint solids rejection. UF tests of solvents containing no aprotic/highly polar solvents (i.e. 2-(B-butoxyethoxy)ethanol, benzyl alcohol, glycol fhenylethers) were carried out with a cellulose acetate - 10,000 MWCO membrane using the filtrate from the 0.7 UM filters as feed. From about 38 to 90 percent of the dissolved paint "solids" was rejected in these tests. Membrane flux varied from 0.04 to $0.2 \mathrm{CCAR} \mathrm{CM}^{2}$ with $\triangle P$ between 650 and 750 psi. Commercially available UF Membranes were not found that are compatible with the aprotic:polar solvents such as $\mathrm{N}$-methylpyrrolidone and ethanolamine.

Based on the successful UF tests with the alcoholether based solvents, it is concluded that MF followed by UF is a feasible process for solvent recovery/recycle. However, the practical application of these processes for most commercially available solvents awaits the development of suitable solvent compatible UF membranes. 


\section{INTRODUCTION AND BACKGROUND}

Chlorinated solvents are being phased out because they are environmentally objectionable, and costly to dispose of. As a result, the CHLORINATED SOLVENT SUBSTITUTION PROGRAM was initiated to find suitable substitutes for chlorinated solvents used for paint stripping, degreasing, and metal cleaning operations; and to develop process to recover and recycle the used non-chlorinated solvents. The recycle/recovery research is aimed at restoring used solvents to their pure andior usable forms. Both distillation and membrane processes are being considered for solvent recycle. This particular subtask is concerned only with membrane processes that might be used for solvent recovery.

The objective of this research was to determine if present Microfiltration (MF) and/or Ultrafiltration (UF) processes can be applied to solvent recycle. The objective was to find suitable MF and UF membranes that will reject particulate matter as well as dissolved "large molecule" contaminants and pass the solvents. The key membrane properties are pore size, porosity, and membrane composition. The pore must be small enough to prevent contaminants from passing, but large enough for solvent molecules to freely pass. Porosity must be high enough so that a resonable permeate flux can be obtained. The membrane material must be chemically inert to the solvent/contaminent species.

The processes are roughly characterized by pore size and/or the size of solute or particulate species that will be rejected as shown below:

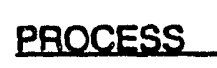

MF

UF

\section{MEMBRANE PORE SIZE}

$$
0.1-10 \mu \mathrm{M}
$$

$$
0.001-0.1 \mu \mathrm{M}
$$

\section{SMALLEST SPECIES REJECTED}

paint pigrnents, bacteria, red blood cells

virus, protein molecules 1000 . $100,000 \mathrm{MW}$

Many proprietary processes and materials are used to manufacture these membranes. Only commercially available membranes were considered for this investigation. However, based on inquires to both domestic and foreign manufacturers, very few UF membranes are being made that OP, compatible with the solvents being tested. 


\section{MATERIALS}

Paint stripping, degreasing, and metal cleaning tests of non-chlorinated solvents are being carried out elsewhere as different subtasks. Paint loaded solvents from paint stripping operations were simulated for the membrane tests by contacting paint chips with the candidate solvents in a stirred flask fitted with a water cosled condenser. The paint chips were obtained by INEL from a company specializing in paint removal by "blasting" the painted surface with solid $\mathrm{CO}_{2}$. The various solvents were loaded with paint chips as shown in table 1. Heating of the solvent-paint chip mix was continued with constant agitation for 48 hours.

\section{TABLE 1. SOLVENT LQADING WITH PAINT CHIPS}

\begin{tabular}{|c|c|c|c|c|c|c|}
\hline \multicolumn{2}{|c|}{ Number } & Solvent & $\begin{array}{l}\text { Temperature } \\
\left({ }^{\circ} \mathrm{F}\right)\end{array}$ & $\begin{array}{l}\text { Solvent } \\
\text { Amount } \\
\text { (gram) }\end{array}$ & $\begin{array}{l}\text { Water } \\
\text { Amount } \\
\text { (gram) }\end{array}$ & $\begin{array}{l}\text { Paint Chips } \\
\text { (gram) }\end{array}$ \\
\hline \multicolumn{2}{|c|}{1} & $\begin{array}{l}\text { Fine organics } \\
\text { FO } 606\end{array}$ & ambient & 900 & -- & 100 \\
\hline \multirow{2}{*}{\multicolumn{2}{|c|}{2}} & \multicolumn{2}{|l|}{$\begin{array}{l}\text { Frederick Gumm } \\
\text { Clepo }\end{array}$} & & & \\
\hline & & & & & & 100 \\
\hline$x$ & 3 & Exxon Exxate 1000 & 140 & 900 & $\cdots$ & 100 \\
\hline$x$ & 4 & $\begin{array}{l}\text { BioTek no. } 140 \\
\text { Saf Solv }\end{array}$ & 150 & 900 &.- & 100 \\
\hline \multirow[t]{6}{*}{$x$} & 5 & Patclin \#126 & 180 & 900 & -. & 100 \\
\hline & 6 & $\begin{array}{l}\text { Turco T5668 } \\
\text { wi seal }\end{array}$ & 150 & 900 & $\cdots$ & 100 \\
\hline & \multirow[t]{2}{*}{7} & \multicolumn{2}{|l|}{ Rochester } & & & \\
\hline & & Midland PSS 600 & 150 & 900 & $\cdots$ & 100 \\
\hline & 8 & $\begin{array}{l}\text { McGean Rohco } \\
\text { CEE BEE A } 245 \text { w/ } \\
\text { seal }\end{array}$ & 240 & 900 & $\cdots$ & 100 \\
\hline & 9 & GAF m-Pyrol & 150 & 900 & $-\cdot$ & 100 \\
\hline \multirow[t]{2}{*}{$x$} & 10 & $\begin{array}{l}\text { Orange Sol } \\
\text { De-Solv-it }\end{array}$ & 140 & Ong & - & \\
\hline & 11 & $\begin{array}{l}\text { McGean Rohco } \\
\text { CEE BEE A477 wiseal }\end{array}$ & 180 & 900 & -. & 100 \\
\hline
\end{tabular}


The composition of the solvents are given in table 2:

\section{TABLE 2. COMPOSITION OF SOLVENTS}

SOLVENTS

FINE ORGANICS FO 606

FREDERICK GUMM CLEPO

ENVIRONSTRIP 222

PATCLIN \#126

TURCO T5668 W/SEAL

ROCHESTER MIDLAND PSS 600

MCGEAN ROHCO CEE BEE

A 245 WISEAL

GAF M PYROL

MCGEAN ROHCO CEE BEE

A 477 W/SEAL

\section{APPROXIMATE SOLVENT COMPOSTION}

ETHANOL AMINE $30 \%$, ETHYLATED NONYI. PHENOL 6\%, N-METHYLPYRROLIDONE 50\%, WATER $14 \%$. 20\% MINERAL OIL SEAL

DODECYL BENZENE SULFONIC ACID 25\%, ETHYLENE GLYCOL PHENYL ETHER 65\% DIETHYLENE CLYCOL PHENYL ETHER 10\%

WATER $20 \%, \quad 2(B-B U T O X E T H O X Y) E T H A N O L$ $50 \%$, AL.KANE SULFONIC ACID 30\%

POTASSIUM HYDROXIDE 5\%, MONOETHANOL AMINE $30 \%$, N-METHYLPYRROLIDONE $45 \%$, HYDROTREATED NAPHTHENIC DISTILLATE $15 \%, \quad N-B U T Y L$ and N-ETHYL.P.TOLUENE SULFONAMIDE $5 \%$. WITH $20 \%$ MINERAL OIL SEAL

N-METHYLPYRROLIDONE 100\%

BENZYL ALCOHOL 94\% UNKNOWN 6\% WITH 20\% MINERAL. OIL SEAL

N-METHYLPYAROLIDONE 100\%

ETHANOLAMINE 100\%. WITH 20\% MINERAL OIL SEAL

NOTE: Compositions based on distillations carried out at MSU together with data presented by the solvent manufacturer on material safety data sheets - constituents have been confirmed, percentages are approximate.

\section{MICROPARTICLE FILTRATION}

Loaded solvents were first filtered through Whatman \#1 filter paper (11 $\mu \mathrm{M}$ retention), then through Whatman GF,F microfiber filter discs $(0.7 \mu \mathrm{M}$ retention) to remove particulate matter. In general the loaded solvents were very viscous and difficult to filter; requiring several hours in a conventional filter flask with house vacuum on the flask. Residual solvent was evaporated from the particulate matter by 
placing the solids.filter paper in an oven overnight at $150^{\circ} \mathrm{C}$. The fraction of solids recovered by microparticle filtration is shown in table 3.

TABLE 3. PERCENT OF PAINT

SOLIDS RECOVERED BY MICROPARTICLE FILTRATION

WT. PERCENT OF PAINT SOLIDS

SOLVENTS

FINE ORGANICS FO 606

FRED GUMM CLEPO

PATCLIN \# 126

TURCO T5668

ROCHESTER MIDLAND PSS 600

MCGEAN ROHCO A-245

GAF M-PYROL

MCGEAN ROHCO A-477 $114 \mathrm{M}$ RETAINED ON FILTER

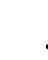

$\begin{array}{ll}78.7 & 0.06 \\ 51.0 & 0.39 \\ 47.4 & 0.35 \\ 51.9 & 0.96 \\ 58.6 & 1.03 \\ 51.9 & 0.96 \\ 63.2 & 0.72\end{array}$

\section{UF MEMBRANES AND TESTS}

In an effort to identify commercially available membranes suitable for the solvent recycle process, inquiries were made to 22 membrane manufactureres(10 USA, 4 Japan, 8 European). These companies are listed in the appendix. Most of the companies never replied, and those that did indicated that none of their membranes were compatible with the paint stripping solvents.

In addition, most of the catalogs from chemical and laboratory supply companies were pursued to see if membranes could be supplied through these vendors.

These efforts resulted in 6 membranes to try as listed in Table 4. 


\section{TABLE 4, UF MEMBRANES: SOURCE AND CHARACTERISTICS}

\author{
SQURCE \\ GOODFELLOW CORPORATION \\ MALVERN,PA \\ SPECTRUM \\ HOUSTON TEXAS \\ MEMERANE DEVELOPMENT SPECIALISTS \\ ESCONDIDO, CALIFORNIA
}

\author{
MEMBRANE CHARACTERISTICS \\ PTFE $.02 \mu$ PORES $\times 0.085 M M$ thick \\ PTFE $.02 \mu$ PORES $\times 0.225 \mathrm{~mm}$ thick \\ (backed with $0.15 \mathrm{~mm}$ POLYPROPYLENE FABRIC) \\ MOLECULAR POR TYPE C CELLULOSE ACETATF - \\ DISC MEMBRANE, 10,000 MWCO \\ EXPERIMENTAL MEMBRANES \\ DESIGNATED $V X, N-25, K-50$ COMPOSITION \\ AND PORE SIZE UNKNOWN.
}

\section{UF TESTS}

The UF test apparatus is shown schematically in Figure 1. It consists of a metering pump (MILROYAL COIJTROLLED VOLUME PUMP, MODEL A-1), membrane test cell, back pressure regulator together with appropriate feed and product reservoirs. The test cell provides support for the thin membrane, and separates the system into feed and product (permeate) regions. The cell body consists of two stainless steel flanges which are held together by a large compassion nut. A porous stainless steel disc fits snuggly into a cavity machined into the low pressure side and provides the necessary support for the membrane, while allowing flow of the permeate out of the cell. Two 0-rings, one in eithe! half of the cell are placed in machined grooves to provide the necessary seals from the atmosphere. and between the feed and permeate side of the membrane. The high pressure half of the cell includes a feed inlet, a cavity for flow past the membrane surface, and a reject outlet. The low pressure half consists of the porous support disc, and the permeate outlet. Exposed membrane area is $17 \mathrm{~cm}^{2}$.

Back pressure is maintained on the feed side of the test cell with a grove. "MITY MITE" back pressuie regulator.

All candidate UF membranes were tested for solvent compatibility by placing fresh solvent on the membrane surface and visually observing any membrane deterioration. Solvents containing ethanolamine and/or $\mathrm{N}$-methylpyrrolidone dissolved the cellulose acetate membrane as well as the membrane coating on the MDS K-50 and $V X$ membranes. The solvent compatible membranes were . 


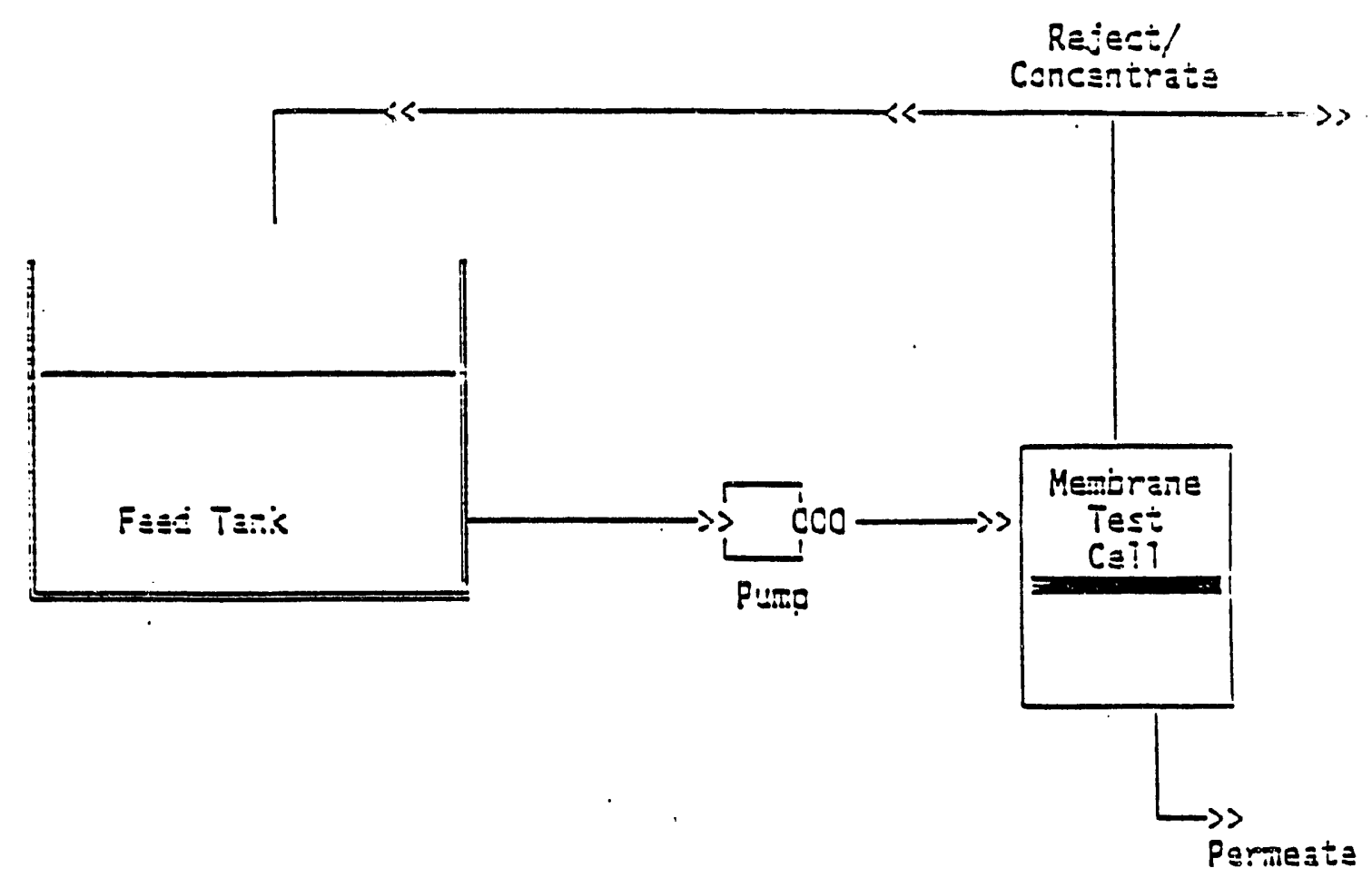


tested by mounting the membrane in the test cell and circulating feed (filtrate from the $0.7 \mu M$ microparticle filtration) through the cell under pressure, back to the feed reservoir

Dissolved solids in the feed, permeate, and fresh solvent were determined by simple evaporation!: A weighed amount of solvent was placed in ceramic evaporation dishes and the solvent evaporated from the solids by placing the dishes in an oven maintained at $150^{\circ} \mathrm{C}$ overnight. In some cases the fresh solvent contained considerable dissolved solids (i.e. potassium hydroxide), or material that produces solids on decomposition (dodecyl-benzene sulfonic acid).

The results of the UF tests are presented in Table 5. 
TABLE 5. RESULTS OF UF TESTS FOR DISSOLVED

PAINT SOLIDS REJECTION

A. 0.02 UM PORE TEFLON MEMBRANE (RESULTS WERE SIMILAR FOR BOTH MEMBRANES)

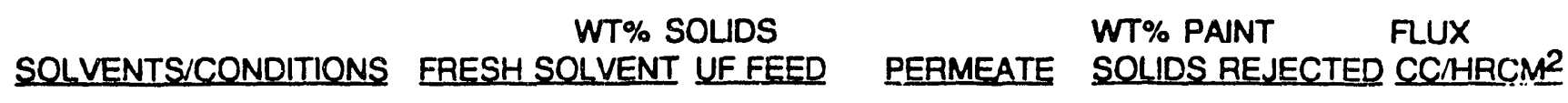

$\begin{array}{lrrrrrr}\text { FINE ORGANIC } & 600 \mathrm{psi} & 3.7 & 10.2 & 10.1 & \ldots . . & 0.22 \\ \text { FRED GUMM } & 50 \mathrm{psi} & 17.9 & 14.7 & 14.9 & \ldots . . & 2.76 \\ \text { TURCO 5668 } & 35 \mathrm{psi} & 6.9 & 10.2 & 10.8 & \ldots . . & 1.62\end{array}$

\section{B, 10,000MWCO SPECTRUM TYPE C (CELLLULOSE ACETATE)}

\begin{tabular}{|c|c|c|c|c|c|c|}
\hline SOLVENTSICONDITIONS & \multicolumn{2}{|c|}{$\begin{array}{c}\text { WT\% SOLIDS } \\
\text { FRESH SOLVENT UF FEED }\end{array}$} & PERMEATE & \multicolumn{3}{|c|}{$\begin{array}{lc}\text { AVERAGE } \\
\text { WT\% PAINT } & \text { FLUX } \\
\text { SOLIDS REJECTED } & \text { CC/HRCM } \\
\end{array}$} \\
\hline $\begin{array}{l}\text { FRED GUMM } 222750 \text { psi } \\
\text { FRESH SOLVENT } \\
\text { PAINT LOADED SOLVENT }\end{array}$ & $\begin{array}{l}21.0 \\
17.7\end{array}$ & $\begin{array}{l}21.0 \\
15.2\end{array}$ & $\begin{array}{l}18.5 \\
13.0\end{array}$ & $\cdots$ & & $\begin{array}{l}0.02 \\
0.05\end{array}$ \\
\hline PATCLIN \#126 & 1.6 & 9.3 & $\begin{array}{l}5.1 \\
4.0 \\
3.2 \\
3.9\end{array}$ & $\begin{array}{l}37.7 \\
51.7 \\
61.7 \\
52.9\end{array}$ & $\begin{array}{l}-\because \\
\therefore \\
\therefore\end{array}$ & $\begin{array}{l}0.16 \\
0.07 \\
0.06 \\
0.05\end{array}$ \\
\hline $\begin{array}{c}\text { MCGEAN ROHCO A-245 } \\
\text { FRESH SOLVENT } \\
\text { PAINT LOADED SOLVENT } \\
650 \mathrm{psi}\end{array}$ & $\begin{array}{l}1.91 \\
1.91\end{array}$ & $\begin{array}{l}1.91 \\
4.45\end{array}$ & $\begin{array}{l}1.40 \\
1.65\end{array}$ & 90.5 & & $\begin{array}{l}0.07 \\
0.04\end{array}$ \\
\hline \multicolumn{7}{|c|}{ C. N-25 MEMBRANE DEVELLOPMENT SPECLALIST EXPERIMENTAL MEMBRANE } \\
\hline $\begin{array}{l}\text { TURCO T566; } 350 \mathrm{psi} \\
\text { MCGEAN ROHCO A-245 } \\
350 \text { psi }\end{array}$ & $\begin{array}{l}6.9 \\
2.0\end{array}$ & $\begin{array}{r}10.6 \\
4.8\end{array}$ & $\begin{array}{r}10.3 \\
4.6\end{array}$ & $\begin{array}{l}8.0 \\
9.0\end{array}$ & & $\begin{array}{l}0.90 \\
0.60\end{array}$ \\
\hline $\begin{aligned} \text { NOTES: (1) FRED GUMM } \\
\text { (2) CALCULATIO } \\
\text { ARE NOT RE }\end{aligned}$ & $\begin{array}{l}\text { A SOLVENT IS } \\
\text { ONS FOR PAT } \\
\text { EJECTED BY }\end{array}$ & $\begin{array}{l}\text { HOMO } \\
\text { LLVEN } \\
\text { LNE }\end{array}$ & $\begin{array}{l}\text { NEOUS MIX7 } \\
\text { SSUMES TH }\end{array}$ & $\begin{array}{l}\text { IRE, } \\
\text { T SOLIDS }\end{array}$ & & $=R E S H$ SOLVENT \\
\hline
\end{tabular}




\section{DISCUSSION}

From about 47 to 80 percent of paint solids in the loaded solvents was recovered by microparticle filtration :hrough filters that reject $11 \mu \mathrm{M}$ and greater particles; while an additional 0.1 to 1.0 percent was rejected by the $0.7 \mu \mathrm{M}$ filter. Evaporative analysis of the filtrate from the $0.7 \mu \mathrm{M}$ filtration showed that the used solvents containea from about 4 to 15 wt. percent "solids" depending on solvent. These compositions are generally consistent with the amount of paint chips recovered by microparticle filtration; that is from about 20 to $5 ?$ percent of the weight of the paint chips is dissolved in the solvents.

In general the solvents loaded with paint chips were very viscous and difficult to filter through the Whatman \#1 paper, requiring several hours using $11 \mathrm{~cm}$ diameter filters and house vacuum. Filtration rate was greatly increased by frequent changing of the filter paper. No judgement was made as to the degree of filtration difficulty among the solvents, however.

Ultrafiltration through either $0.02 \mu \mathrm{M}$ teflon membrane resulted in no apparent dissolved paint solids rejection. UF with aprotichighly polar solvents such as those containing ethanolamine and/or $\mathrm{N}$ methylphrrolidone could not be carried out with membranes other that the teflon films since other solvent compatible membranes apparently do not exist. Inquires were made of 2.2 domestic and foreign companies who manufacture UF membranes with no indication that UF membranes with suitable pore characteristics are now manufactured from materials that are compatible with these solvents.

UF tests with alcohol and ether based solvents (2-(B-butoxyethoxy)ethanol, benzyl alcohol, glycol phenyl ethers) using a SPECTRUM TYPE C (cellulose acetate) membrane characterized as having pores with 10,000 MWCO confirmed the technical feasibility of using UF for solvent recovery from paint loaded solvents. This membrane rejected over 90 percent of the dissolved paint solids from the McGean Rohco A-254 solvent. from about 38 to 62 percent from the PATCLIN \#126 solvent, and a significant but undetermined amount from the FRED. GUMM 222 solvent. This membrane also rejected 27 percent of the solids from fresh McGean Rohco A-245 Solvent and 24 percent of the solid from fresh Fred. Gumm solvent. Paint solids rejection from the GUMM solvent could not be determined because the fresh solvent contains more "solids" than the permeate. It was later discovered that this solvent is not a homogeneous mixture, which accounts for the difficulty in analysis. However, in all cases a high (650-750psi) pressure was required to obtain a measurable permeation rate. 
Although these tests confirmed the technical feasibility of recycle paint solvents by UF, the practical application would require membrane system engineered for this use. These membranes would require much higher porosity than the laboratory films used in this study. Indeed, better membranes that might be applied to the alcohol/ester solvents probably now exist. For example, we obtained literature from DOW/DANMARK separation systems that indicates they manufacture polyvinylidenefluoride UF membranes with pore characteristics between 100,000 and 6,000 MWCO. Dow claims water flux through these membranes in the range of 200-500 LM $\mathrm{M}^{2} \mathrm{HR}$ with maximum operating pressure between 10 and 15 bar. These membranes could probably be applied to the alcohol/ether based solvents but attempts to obtain membrane samples for testing have been unsuccessful to date.

Application of UF to recycle of solvents such as $\mathrm{N}$-methylpyrrolidone and ethanolamine awaits development of membranes from materials that are compatible with those solvents. 
APPENDIX A

OSMONICS

5951 CLEARWATER DRIVE

MINNETONKA, MINNESOTA 55343

ABCOR, INC.

850 MAIN STREET

WILMINGTON, MA 0;887

AMICON CORP

21 HARTWHEEL AVENUE

LEXINGTON, MA 02173

DESALINATION SYSTEMS, INC 1107 WEST MISSION AVENUE ESCONDIDO, CA 92025

DORR-OLIVER

77 HAVEMEYER LANE

STANFORD, CT 06904

MILLIPORE CORP

ASHBY ROAD

BEDFORD, MA 01730

NUCLEPORE CORP

7035 COMMERCE CIRCLE

PLEASANTON, CA 94566

ROMICON INC.

100 CUMMINGS PARK

WOBURN, MA 01801

DOW CHEMICAL

SEPARATION SYSTEMS

100 LARKIN CENTER

MIDLAND, MICHIGAN 48674

MEMBRANE DEVELOPMENT SPECIALISTS

1313 SIMPSON WAY, SUITE E

ESCONDIDO, CA 92025

ASAHI GLASS COAP

2-1-2, MARUMOUCHI

CHYODA-KU, TOKYO

JAPAN

NITTO ELECTRIC INDUSTRIAL CO., LTD

1-1-2, SHIMOHOZUMI, IBARAKI

OSAKA

JAPAN
DAICEL CHEMICAL INDUSTRIES, LTD

8-1, 3-CHOME, KASUMIGASEKI

CHLYODA-KU, TOKYO 100

JAPAN

TEIJIN, LTD.

MEMBRANE PROJECT

1-1, UCHISAIWAI-CHO 2-CHOME

CHLYODA-KU, TOKYO 100

JAPAN

PATTERSON CANDY INTERNATIONAL, LTD LAVERSTOKE MILL

WHITCHURCH, HAMPSHIRE RG287NR

ENGLAND

RHONE-POULENC

SPECIALITES CHIMIQUES

18, AVENUE d'ALSACE

92400 COURBEVOIE

FRANCE

SOCIETE DE FABRICATION

d'ELEMENTS CATALYTIQUES

BP33

84500 BOLLENE

FRANCE

WAFILIN

P.O. BOX 5

7770 AA HARDENBERG

THE NETHERLANDS

D.D.S. INC.

P.O. BOX 149

4900 NAKSKOV

DENMARK

BERGHOF Gmbh.

P.O. BOX 1523

7400 TUBINGEN 1

WEST GERMANY

KALLE

POSTFACH 3540

620 WIESBADEN 1

WEST GERMANY

SATORIUS Gmbh.

POSTFACH 19

3400 GOTTINGEN

WEST GERMANY 


\section{APPENDIX B}

\section{MICROFILTERATIONULTRAFILTRATION OF WAX LOADED SOLVENTS}

\section{SUMMARY}

Microfilteration through a $0.7 \mu \mathrm{M}$ filter followed by ultrafilteration through a $10,000 \mathrm{MWC} ; 0$ Membrane was investigated as a means of removing wax from loaded solvents. Spent Cleaniric, solvents were simulated by dissolving wax in ORANGE. Sol DE-SOLV-IT and EXXON EXXATE 1000 About 40 percent of the wax is removed by MF. The UF Membrane was swollen by the ORANGE.SOL solvent and made it impremiable. About 5 percent of the wax in the EXXON solvent UF feed was removed by UF.

\section{MFNF TESTS}

Two additional solvents were loaded with wax to simulate waste solvents used in cleaning operations. PETROLITE BE SQUARE 175 wax was dissolved in ORANGE-SOL DE-SOLV-IT and EXXON EXXATE 1000 solvents with loading levels of 50 and $10 \mathrm{~g} / 1$ repectively. At this loading level the: wax was rapidly and completely dissolved in hot $\left(140^{\circ} \mathrm{F}\right)$ solvent, resulting in clear solutions. Both solvents became cloudy as wax crystals precipitated as the loaded solvent's cooled to room temperature. This material was then filtered through the $0.7 \mu \mathrm{M}$ glass microparticle filters with the filtrate being used as feed to the UF (SPECTRUM TYPE C 10,000 MWCO) system. This was the only UF membrane available that appeared to be compatible with these solvents.

Quantative analysis for wax concentration in the various feed and product stream was accomplished by evaporation at $100{ }^{\circ} \mathrm{c}$. Blank determination on the wax showed no loss of wax under evaporation conditions. The result's of the tests are presented below:

\section{RESULTS:}

Solvent compositions as reported by the manufacturer:

ORANGE-SOL DE-SOLV-IT: Mixture of orange oil and technical grade menial oil.

EXXON EXXATE 1000: Mixture of $\mathrm{C}_{9}-\mathrm{C}_{11}$ branched oxo-alcohol esters of acetic acid.

\begin{tabular}{|c|c|c|c|c|c|}
\hline \multirow[b]{2}{*}{ SOLVENT } & \multicolumn{4}{|c|}{ WT. PEACENT WAX } & \multirow[b]{2}{*}{ 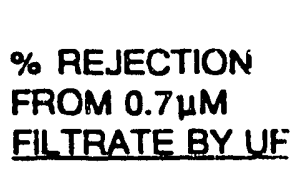 } \\
\hline & $\begin{array}{l}\text { LOADED } \\
\text { SOLVENT }\end{array}$ & $\begin{array}{l}\text { FILTRATE FROM } \\
0.7 \mathrm{MM}\end{array}$ & $\begin{array}{l}\% \text { OF LOADED } \\
\text { WAX RETAINED } \\
\text { ON } 0.7 \text { MM }\end{array}$ & $\begin{array}{l}\text { UF } \\
\text { PERMEATE }\end{array}$ & \\
\hline $\begin{array}{l}\text { ORANGE.SOL } \\
\text { DE-SOLV-IT }\end{array}$ & $5.94 \%$ & 4.71 & 41.0 & $\cdots$ & $\cdots$ \\
\hline EXXON EXXATE & $1.15 \%$ & 0.67 & 46.0 & 0.64 & 6.3 \\
\hline
\end{tabular}




\section{DISCUSSION:}

The wax from the loaded ORANGE.SOL solvent was very difficult to filter through the $0.7 \mu \mathrm{M}$ filter because the large amount of precipitated wax rapidly "blinded" the filters. THe small amount of wax that precipitated from the EXXON Solvent was easily filtered. Forty and forty two percent of the loaded wax was removed form the two loaded solvents by the $0.7 \mu \mathrm{M}$ filter.

No permeate was obtained during the UF test of the ORANGE-SOL solvent after about 7 hours at 750 psi. When the membrane was removed form the test cell it showed considerable swelling.

A reasonable flux was obtained during UF of the EXXON solvent, but soluble wax rejection was low with only about 5 percent of the wax in the UF feed being rejected.

From these results it is concluded that UF through 10,000 MWCO cellulose acetate membrane is not practical for removal of wax from wax loaded solvents. 


\section{Appendix C}

Recovery of Waste Solvents by Rectification, Azeotropic and/or Extractive Distillation 
RECOVERY OF WASTE SOLVENTS BY RECTIFICATION, AZEOTROPIC AND/OR EXTRACTIVE DISTILIATION

By Lloyd Berg, Chemical Engr. Dept., Montana State University, Bozeman, Montana.

The objective of the Solvent Recycle/Recovery Task of the DOE Chlorinated Solvent Substitution Program is to minimize hazardous wastes by identifying recycle/recovery techniques for the proposed substitute solvents.

Solvents are utilized for cleaning, stripping and various other maintenance operations of aircraft parts and equipment. After use, many of the solvents can be recovered and reused. However, several. of the solvents currently in use are chlorinated and emit volatile organic compounds, which are toxic to the environment and to operating personnel.Wastes generated from these solvents are regulated by the U.S. Environmental Protection Agency, and soon use and manufacture of the solvents may be restricted.

The first phase of the program was to examine by distillation the potential solvents as designated by INEL. The following solvents were received and tested. They are listed in Table 1 . All contained the chemical compounds that the manufacturer claimed. The distillation plots for the new and unused solvents are in Appendix $I$.

Table 1 - Solvents Received

Company

EXXON

Orange-Sol

3D

Chemical Solvents

Fine Organics

Frederick Gumm

GAF

Patclin

McGean-Rohco

McGean-Rohco
Product

Designation Compound(s)

Exxate-1000

De-Solv-It

3d Supreme

$S P-800$

FO-606

Clepo 222

M-Pyrol

Hot Strip 126

C B $A-245$

C B $A-477$
Nonyl acetate, Undecyl acetate Mineral oil, Orange ester Dipropylene glycol methyl ether, water N-Methyl pyrcolidinone, Tetrahydrofurfuryl alc. Diethanolamine

N-Methyl pyrrolidinone, Ethanolamine, Water Ethylene glycol phenyl ether N-Methyl pyrrolidinone

2-Butoxyethoxyethanol, water

Benzyl alcohol

Ethanol amine 
Table 1 - Continued

Rochester Midland

Turco

Bio-Tek
PSS -600

$T-5668$

Saf-Solv-140
N-Methyl pyrrolidinone

N-Methyl pyrrolidinone, Ethanolamine

Cetyl acetate, Octadecyl acetate,Decyl acetate

The second phase of the program was to simulate the solvents in the condition that they would be in after being used in paint stripping. This was done by heating and stirring a mixture of the solvent and the paint chips for 48 hours. The tempearure and amount of solvent, water and paint chips atr listed in Table 2 . EXXON Exxate 1000, BioTek-140 and Orange Sol De-Solv-It were eliminated from this test program.

$r:$

-Table 2 Solvent Loading With Paint Chips

\begin{tabular}{|c|c|c|c|c|c|}
\hline Number & colvane & $\begin{array}{c}\text { Tempopature } \\
\left({ }^{\theta} p\right)\end{array}$ & $\begin{array}{l}\text { Dolvent duount } \\
\text { (arem) }\end{array}$ & $\begin{array}{l}\text { Mecer } \\
\text { Amount } \\
\text { (srem) } \\
\end{array}$ & $\begin{array}{l}\text { Pefine } \\
\text { enipe } \\
\text { (grum) } \\
\end{array}$ \\
\hline 1 & Pine Organtes po 606 & anbient & 900 & $\cdots$ & 100 \\
\hline 2 & $\begin{array}{l}\text { Prederick and Elapo } \\
\text { Envirasstio } 22 ?\end{array}$ & 180 & 450 & 450 & 100 \\
\hline 3 & Exxen Exxa:e 1000 & 140 & 900 & 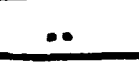 & 100 \\
\hline 6 & Dloiek no. 140 sed soly & 150 & 900 & $\cdots$ & 100 \\
\hline 3 & Doeet in $=126$ & 180 & 900 & 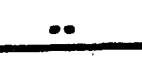 & 900 \\
\hline 6 & TUrso TS668 W/ seal & 150 & 900 & $\cdots$ & 100 \\
\hline 7 & Roeheseer Midland DSS 600 & $150^{\circ}$ & 900 & $\cdots$ & 100 \\
\hline 8 & 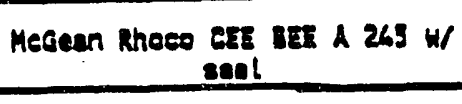 & $\because 240=\because$ & $\therefore \quad \therefore 00 \quad 1$. & 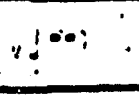 & 100 \\
\hline 9 & as m-eyral & 980. & $900 \quad:$ & 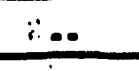 & 100 \\
\hline 10 & Orenae sol Decsolvels & $140 \div !$ & $\infty 00$ & $\because \because$ & 100 \\
\hline i1 & 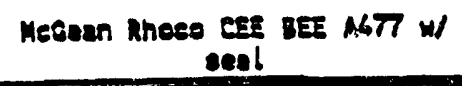 & 980 & 900 & $\bullet$ & 100 \\
\hline
\end{tabular}

- no wasor

The results with the paint chips were as follows: 
This is a report on our run: with Fine organics 606w/Seal. It comprists:

Compound.

Ethanolamine

Ethylated Nonyl Phenol

N-Methyl pyrrolidione

Mineral Oil

Water

\section{Percent Boiling Point}

25

5

45

15

10 $170^{\circ} \mathrm{C}$.

168 \& $5 . \mathrm{sm}$.

202

$150-300$

100

A mixture containing 450 grams of FO $606 \mathrm{~W} / \mathrm{Seal}$ and 45 grams of paint chips was stirred at $25^{\circ} \mathrm{C}$. for 48 hours. The product was filtered. The paint chips remained on the filter; the filtrate formed two liquid layers. The lower layer boiled at $180-200^{\circ} \mathrm{C}$. and had an $\pi_{D}=1.465$. The upper layer boiled at $260-270^{\circ} \mathrm{C}$. and had an $n_{D}=1.473$. The distillation proceeded with a constantly rising boiling point with two plateaus, one at $180-200^{\circ} \mathrm{C}$. and the other at $260-270^{\circ} \mathrm{C}$.

Procedure for Recovering Fine Organics FO $606 \mathrm{w} / \mathrm{Seal}$ After Use as a Paint Remover. $\therefore-\because-\div-\cdots$

Assuming that the $48 \mathrm{hrs}$. at $25^{\circ} \mathrm{C}$. agitation with the paint chips gives the same results as the actual paint removal; the procedure for recovery is as follows:

1. Filter out the paint chips.

2. Allow the liquid to settle into two layers.

3. Separate the two layers by decantation.

4. Distill off the upper layer at $180-200^{\circ} \mathrm{C}$. getting a mixture of ethanolamine and similar boiling hydrocarbons.

5. Distill off the lower layer at $260-270^{\circ} \mathrm{C}$. getting a mixture of N-methyl pyrrolidone and similar boiling hycrocarbons.

6. Distili.off the residue from the above distillations at $168^{\circ} \mathrm{C}$ and $5 \mathrm{~mm}$. Hg getting ethyläted. nonyl phenol.

7. These three distillations will all contain a similar boiling hycrocarion fraction. If pure ethanolamine anc N-methyl pyrrolidone are desired, an azeotropic or extractive distillation process will have to be developed. None is now in existance. 
This is a report on our run with F. Gumn's Clepo Env. \#222. A mixture containing 225 gms. $\frac{n}{4222,} 225$ gms.water and 50 gms. paint chips was stirred at $80^{\circ} \mathrm{C}$. for 48 hours. The product was cooled to room temperature and filtered. A sample of tie paint chips removed is enclosed. The final product separated into two layers, one water, the o-jer phenyl ethers. Samples of these two layers are enclosed to show you the quality (or lack of it) and are marked "crude". The phenyl ethers were distilled in an orcinary distilling flask. Some water is present in this layer and comes off as a two-phase azeotrope at $95^{\circ} \mathrm{C}$. The ethylene glycol phenyl ether then boils off at about $270^{\circ} \mathrm{C}$. and the diethylene glycol phenyl ether boils ofi at above $300^{\circ} \mathrm{C}$. with decomposition. These will have to be recovered by vacuum rectification. Samples of these two fractions are enclosed.

Procedure for Recovering F. Guim's Clepo Env $\$ 222$.

Assuming that the $48 \mathrm{hrs}$. at $80^{\circ} \mathrm{C}$. agitation with the paint chips gives the same results as the actual paint removal, the procedure for recovery is as follows:

1. Filter out the paint chips.

2. Allow the liguid filtrate to settle into two layers, water layer on top.

3. Decant, discarả water layer.

4. Distill the organic layer. The dodecyl benzene sulfonic acid will cause some of the water to dissolve in the phenyl ethers. The first distillation will yield the ethylene glycol phenyl ether - water azeotrope boiling at about $95^{\circ} \mathrm{C}$.

5. Separate the distillate from No. 4 by decantation discarding the water and recovering the ethylene glycol phenyl ether.

6. Rectify under reduced pressure the remaining organic material. Rectification at I Atm. pressure will cause thermal decomposition of the diethylene glycol phenyl ether because it boils above $300^{\circ} \mathrm{C}$. 7. The bottoms fxom No. 6 will contain the decomposed dodecyl ben=e:35 sulfonic acia and any other solics. These go to a landfill.

Note: F. Gumn's Elepo Env. \#222 consists of: 228 dodecyl benzene sulfonic acid, $56.7 \%$ ethylene glycol phenyl ether, $6.3 \%$ diethylene glycol phenyl etier. 
This is a report on our run with Patclin \#126 solvent. It comprises:

Compoung

Water

Alkane Sulfonic Acid

2-Butoxyethoxy ethanol

Percent Boiling Point

27

8

65 $100^{\circ} \mathrm{C}$.

$95^{\circ} \mathrm{C} \& 1 \mathrm{~mm}$.

$115^{\circ} \mathrm{C}$. @ $1 \mathrm{~mm}$.

A mixture containing 450 grams of Patclin $\# 126$ and 50 grams of paint chips was stirred at $82^{\circ} \mathrm{C}$. for 48 hours. The product was filtered. The paint chips remained on the filter.

The distillation procesded with water removal at $100^{\circ} \mathrm{C}$. and then distillation at $1 \mathrm{~mm}$. Hg to remove the alkane sulfonic acid and the 2-butoxyethoxy ethanol.

Procecure For Recovering Patclin 126 After Use as a Paint Remover. Assuming that the 48 hours at $82^{\circ} \mathrm{C}$. agitation witin the paint chips gives the same results as the actual paint removal, the procedure for recovery is as follows:

1. Filter out the paint chips.

2. Distill the liquid phase at 1 Ato. to get the water.

3. Distili the liguid phase at $1 \mathrm{~mm}$.Hg to get off the 2-butoxyethoxy ethanol at $105-115^{\circ} \mathrm{C}$.

This is a report on our Iun with TURCO T-5668 solvent. It comprises:

Compourde

Etianolamine, B.P. $=170^{\circ} \mathrm{C}$.

$\mathrm{N}$-iletiyl pỹzolicone, B. P. $=202^{\circ} \mathrm{C}$.

Eyczogenates Naphthenes

ROE
Percent Boiling Point

22

60

10

2
$65-75 € 1 \mathrm{~mm}$. $75-85$ @ $1 \mathrm{~mm}$. $>170$ @ $1 \mathrm{~mm}$. Hg.

A mixture contining 450 grams of TURCO T-5663 and 50 grams of paint chizs was stirzec at $60^{\circ} \mathrm{C}$. for 48 hours. The procuct was filterea. The paint chips remained on tie filter.

The distillation procesied with etianolamine removal at $65-75^{\circ} \mathrm{C}$. at $1 \mathrm{~mm}$ Eg followes by tie N-Methyl py=rolicone at 75 - $85^{\circ} \mathrm{C}$ at $1 \mathrm{~mm}$. Eg. The hycrogenater: naphihenes and the ROE remaines in tie resicue. 
Procesure For Recoveriag MURCO T-5668 Solvent Aftez Use As A Paint Removi Assuning tiat tie 48 hours at $66^{\circ} \mathrm{C}$. agitation with the paint cipips gives the same results as tie actial paint removal, tije procecure for recovery is as follows:

1. Filter out the paint chips.

2. Rectify the liquid phase in colum containing at least 23 theoretical plates. Take off ethanolamine at $170^{\circ} \mathrm{C}$ and 998 purity. Relative volatility is about 1.5 which requires 23 T.P. to get 99 of purity. 3. When ethanolamine is exhausted, continue rectification to get the $\mathrm{J}$-methyl-1-pyrrolidone at $202^{\circ} \mathrm{C}$. and $99 \mathrm{~g}$ purity.

4. Withdraw hydrogenated napthenes for use as recycle. All impurities will wind up in napthene fraction wich will have to redistilled eventuall

This is a report on our run with Rochester Midiand PSS 600 Solvent.: It comprises $1008 \mathrm{~N}$-methylpyrrolidone.

A mixture containing 450 grams of R-M PSS 600 and 50 grams of paint chips was stiered at $66^{\circ} \mathrm{C}$. for 48 hours. The product was filtered. The paint chips remained on the filter.

The distillation proceeded with the removal of the N-metiyl pyrrolidone at $73^{\circ} \mathrm{C}$. at $1 \mathrm{~mm}$. Hg.

Procecure For Recovering Rochester Micland PSS 600 After Use As A

Paint Remover.

Assuming that the 48 hours at $66^{\circ} \mathrm{C}$. agitation with the paint chips gives the same results as the actual paint removal, the procedure for recovery is as follows:

1. Filter out the paint chips.

2. Distill the liguid phase at $1 \mathrm{~mm}$. Hg at get the $\mathrm{N}$-methyl pyrrolidone at $73^{\circ} \mathrm{C}$. 
This is a report on our Iun with MCGeon-Rohco CEE BEE A-245 Solvent. It comprises:

\section{Compounas}

Benzyl alcohol

Unknown
Percent Boiling Point

6 $93-98^{\circ} \mathrm{C}$. $1 \mathrm{~mm}$.

A mixture containing 450 grams of CEE BEE A-245 and 50 grams of paint chipswes stirred at $116^{\circ} \mathrm{C}$. for 48 hours. The product was filtered. The paint chips remained on the filter.

The distillation proceeded with the removal of the benzyl alcohol at 93-98 C. at $1 \mathrm{~mm}$. Hg. A small amount of residue accumulated in the stillpot.

Procedure For Recovering CEE BEE A-245 After Use As A Paint Remover. Assuming that 48 hours at $116^{\circ} \mathrm{C}$. agitation with the paint chips gives the same results as the actual paint removal, the procedure for recovery is as follows:

1. Filter out the chips.

2. Distll the liguid phase at $1 \mathrm{~mm}$. Eg. to get the benzyl alcohol at $93-98^{\circ} \mathrm{C}$.

3. Discard the residue.

This is a report on our Iun with GAF m-Pyrol solvent. It comprises N-metingl pyrrolicone.

A mixture containg 450 grams of GAF m-Pyrol and 50 grams of paint chips was stirred at $66^{\circ} \mathrm{C}$. for 48 hours. The product was filtered. The paint chips remained on the filter.

The istillation proceeded with the removal of the $\mathrm{N}$-methyl pyrrolidone at $73-76^{\circ} \mathrm{C}$. I Imm. Hg. $n_{D}=1.4600$ (pure is 1.

Procecure For Recovering GAF m-Pyrol After use As A Paint Remover. Assuming that the 48 hours at $66^{\circ} \mathrm{C}$. agitation with the paint chips gives the same results as the actual paint removal, the procedure for recovery is as follows:

1. Filter out the paint chips.

2Distill tie liquid phase at I m. Hg to get the N-methyl pyrrolidone 
This is a report on our Iun with MCGeon-Rohco CEE BEE A-477 Solvent. It comprises:

Suppliers our

Compounčs Analysis \& Analysis \& Boiling Point

Ethanolamine $\quad 50 \quad 65 \quad 65-72^{\circ} \mathrm{C}$ @ $1 \mathrm{~mm}$. Hg

Mineral Oil $50 \quad 35 \quad 170^{\circ} \mathrm{C}$. \& higher \& I mm. Hg.

A mixture containing 450 grams of CEE BEE A-477 and 50 grams of paint chips was stirred at $82^{\circ} \mathrm{C}$. for 48 hours. The product was filtered. The paint chips remained on the filter.

The filtrate formed two liquid layers which were decanted. The lower layer, the ethanolamine, distilled off at $65-72^{\circ} \mathrm{C}$. The upper layer, the mineral oil, was separately distilled at $>170^{\circ} \mathrm{C}$. \& I $\mathrm{mm}$. $\mathrm{Hg}$. The purity of the ethanolamine obtained in this one theoretical plate distilling flask was $99 \%$. The $n_{D}$ was 1.458; pure ethanolamine is 1.454. Procedure For Recovering CEE BEE A-477 After Use As A Paint Remover. Assuming that 48 hours at $82^{\circ} \mathrm{C}$. agitation with the paint chips gives the same results as the actual paint removal, the procedure for recovery is as follows:

1. Filter out the chips.

2. Decant the two imriscible liquid layers that form.

3. Distill thelower layer at $65-72^{\circ} \mathrm{C}$. at $1 \mathrm{~mm}$. Hg getting at least 988 of the ethanolamine in 998 purity. Discard the residue,. less than $5 \%$. 4. Distill the upper layer at $170^{\circ} \mathrm{C}$. and greater at $1 \mathrm{~mm} \mathrm{Hg}$ to recover the mineral oil (hydrocarbon) layer. Discard the residue; less than $5 \%$.

An economic evaluation of the process to recover and recycle the used solvents was done. The GAF M-Pyrol study represents a single compound solvent and the TuRCO T-5668 is a study for a multicomponent mixture. 
The following is an economic evaluation for the recovery of GAF COIP. M-PYROI spent solvent.

M-PYROL is $\mathrm{N}$-metinyl pyrrolicione, B.P. $=202^{\circ} \mathrm{C}$. , Density $=1.026$ $30,000 \mathrm{gal} / \mathrm{yr} . \times 8.337 \mathrm{~m} / \mathrm{gal} \times 1.026=257,000 \frac{\mathrm{n}}{\mathrm{T}} / \mathrm{yr}$. $257,000 \frac{\mathrm{z}}{\mathrm{T}} / \mathrm{yr} \times 1 / 365 \times 1 / 24=293 / \mathrm{hr} \times 125$ overdesign $=37 \frac{\mathrm{t}}{\mathrm{t}} / \mathrm{hr}$. Allowable vapor velocity $=1.0 \mathrm{ft} / \mathrm{sec}$. $37 \pi / \mathrm{hr} \times 1 / 0.2 \frac{\mathrm{n}}{\pi} / \mathrm{ft}^{3} \times 1 / 3600 \mathrm{sec} / \mathrm{hr}=0.15 \mathrm{ft}^{3} / \mathrm{sec}$. Rurring 30,000 gal/month: $0.15 \mathrm{ft} 3 / \mathrm{sec} \times 12=1.8 \mathrm{ft}^{3} / \mathrm{sec}$. $1.8 \mathrm{ft} / \mathrm{sec} / 1 \mathrm{ft.} / \mathrm{sec}$. $=1.8 \mathrm{ft}^{2}$, which $=18^{\mathrm{n}}$ colum diameter Assuming 99 purity of overhead \& bottoms, rel. vol. $=2,13$ theor.plate $257,000 \frac{n}{\pi} /$ mo. $\times 1 / 30 \times 1 / 24=3603 / \mathrm{hr} \times 125 \%=450 \frac{\mathrm{n}}{\pi} / \mathrm{hr}$. $450 \frac{\mathrm{H}}{\mathrm{H}} \mathrm{hr} \times 250 \mathrm{Btu} / \frac{\mathrm{n}}{\mathrm{T}}=112,500 \mathrm{Btu} / \mathrm{hr}$ to condense $450 \frac{n}{\pi} / \mathrm{hr} \times(202-30) \times 1.8 \times 0.5=70,000$ Btu/hr to cool $112,500+70,000=200,000 \mathrm{Btu} / \mathrm{hr}$ in concense $200,000 \times 1 / 120 \times 1 / 150=11 \mathrm{ft}^{2}$ $70,000 \times 1 / 200 \times 1 / 50=7 \mathrm{ft}^{2}$

Richard Rall; Koch Engr. Co., Wichita, RS. estimated the column \& condensers as follows:

columns, pumps, colunn internals, reflux tank, heat exchangers

\& contzols

Bidding, designs \& simulation $\$ 100,000$

Assembing 100,000

Putting on skids 50,000

Storage tanks 20,000

Piping \& Electrical installation 15,000 Contingency 80,000 - Total Investment

Arnual Erperses

Osez=Eing Labor: $\$ 40 / \mathrm{hr} \times 2$ geople $\times 168 \mathrm{hr} / \mathrm{mo} \times 5 \mathrm{mos} .=\$ 67,000$ supergision: $\$ 50 / \mathrm{hr} \times 42 \mathrm{hr} / \mathrm{mo}$. $\times 5 \mathrm{mos}$. 10,500 Maintenance \& Repaizs 15,000

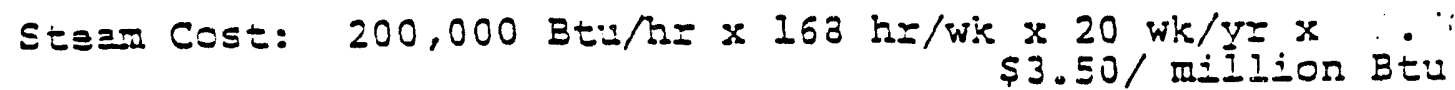
2,350 Sluçe Recovery \& Disposal 
Moving Expenses

Depreciation - $10 \%$ per year

Properzy tares \& $3 \%$

Total Expenses $\therefore 50,000$

45,000

13,500

$\$ 303,350$

Revenue: $\quad \$ 2,185,000$

Total Expenses $\frac{303,350}{\$ 1,881,650}$

Net Income, $\$ 1,881,650$

beEore Income tax

This is an economic evaluation of the recovery ofTuRco T-5668 solvent whici comprises 228 ethanol amine, $608 \mathrm{~N}$-methyl pyrrolidinone and 108 hycrogenated raphtheres.

The recovery procedure is as follows:

1. Filter out the paint chips.

2. Rectify the liquid phase in a batch column. Distill off the ethanolamine at $170^{\circ} \mathrm{C}$. and 998 purity.

3. Put midfraction, ethanolamine and $\mathrm{M}$-Pyrol in storage tank for resycl

4. Distill off the $M-$ Pyrol at $202^{\circ} \mathrm{C}$.

5. Put micizaction, M-Pyrol and naphthenes in storage tank for recycle.

6. Distill oミミ napithenes at $170^{\circ} \mathrm{C}$ anc resuced pressure.

7. Empty stillpot, send to waste.

8. Refill stillpot with new charge plus both midfraction recycle streams from previous run.

Bateh operation and midfraction recovery about 508 more time. Batch operation reguires extra charge capacity for recycle fraction.

INVESTMENT

Colum, punses, colum interials, reflux tank, heat exchangers \& controls $\$ 100,000$ Bidiing, designs \& simulation

Assemiling 100,000

Putting on skics 50,000

Storage tanks

Pipime \& electrical installation 20,000 30,000

Contingency

Total Investment 
Ansual Expenses - Five sources, 150,000 gallons per year

Operating Labor: \$40/hr $\times 2$ people $\times 24$ re/cay $\times 240$ days $=\$ 450,800$

Supervision: . \$50/hr x $42 \mathrm{hr} / \mathrm{mo} \times 8$ mos 16,800

Maintenance \& Repairs 15,000

Steam Cost: $200,000 \mathrm{Btu} / \mathrm{hI} \times 168 \mathrm{hr} / \mathrm{wk} \times 32 \mathrm{wk} / \mathrm{Yr} \times \$ 3.50 \mathrm{M} \quad 3,760$

Slucige Recovery. \& Disposal

100,000

Moving Expense

50,000

Depreciation - $10 \%$ per year

46,500

Property Taxes 8 3\%

14,000

TOTAL EXPENSES

$\$ .706,860$

Reveaue:

Ethanolamine: 150,000 gal $\times 8.55 \times 228 \times \$ 0.59$

$\$ 166500$

M-PyI01: $\quad 150,000 \mathrm{gal} \times 8.55 \times 60 \% \times \$ 1.70$

$1,308,150$

Eyarogenated Naphthenes: $150,000 \times 8.55 \times 10 \% \times \$ 0.20$

25,650

TOTAL REVENUE

$\$ 1,500,300$

Net Income: $\$ 1,500,300-\$ 706,860=\$ 793,440$

Return or Investment: $\$ 793,440 / 7465,000=171 \%$

Payout Time: 7 months

Annual Expenses: Operating one plant, 1.5 months, 30,000 gallons

Operating Labor: $\$ 40 /$ hr $\times 2$ people $\times 24 h r / d \times 45$ days

supervison: $\$ 50 / \mathrm{hr} \times 10 \mathrm{hr} / \mathrm{wk} \times 6$ weeks

Maintenance \& Repairs

Steam Cost: $200,00 \mathrm{Btu} / \mathrm{hr} \times 168 \mathrm{hr} / \mathrm{wk} \times 6 \mathrm{wk} / \mathrm{mo} \times \$ 3.50 / \mathrm{M}$

$\$ 86,400$

Sludge Recovery \& Disposal

Depreciation - 108 per yI

Properiy tares e 38

Total Expenses

3,000

15,000

700

100,000

46,500

$\frac{14,000}{\$ 265,600}$

Revenue:

Ethanolamine: 30,000 gal $\times 8.55 \times 223 \times \$ 0.59 / 1 \mathrm{~b}$

$\$ 33,300$

261,630

M-Pyrul: $\quad 30,000 \mathrm{gal} \times 8.55 \times 608 \times \$ 1.70 / 1 \mathrm{~b}$

Hycrogenated Naphthenes; 30,000 gal $\times 8.55 \times 108 \times \$ 0.20 / 1 b \frac{5,130}{\$ 300,060}$ Total Reverue

Net Income: $\$ 300,060-\$ 255,600=\$ 34,460$

Return on Investment: $\$ 34,460 / \$ 465,000=7.4 \%$

payout Time: 13.5 years 
SOIVENT \& WAX RECOVERY

Two solvents were mixed with Petrolite BE SQUARE \#175 Amber wax as follows:

EXXATE 1000 - $10 \mathrm{gm}$ wax/liter

Orange Sol De-Solv-It - $50 \mathrm{gm}$ wax/liter

Both solvent-wax mixtures foamed when distilled. The following anti-foaming agents were investigated:

EXXON Corexit 362

n Surflo AF 2436

" $\quad$ AF 7669

" AF 8574

PPG MAZ TREAT 246

" MAZU DF 200 SX

" Macol 5100

Genesee DB 12

Union Carbide SAG 47

" SAG 1000

None of the above anti-foaming agents were effective in reducing the foaming.

$\frac{-\therefore-\therefore-\cdots}{\text { Lloyd Berg }}$ 
APPENIX 1 - Distillation Results, New Solvents (unused) 


\section{DATA ACCUMULATION SHEET}

CHLORINATED SOLVENT SUBSTITUTION PROGRAM

SOLVENT RECYCLE/RECOVERY TASK

TEST CONDITIONS:

Parameter

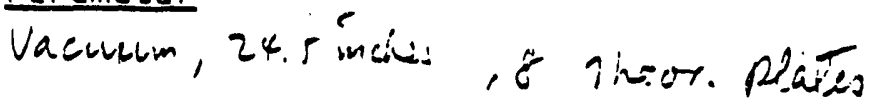

CONDITION

Solvent Name Goumh Erede 1:a0

Distillation Procedure Simple Batch $X$ Extractive ___ Azeotropic

Recovered Component, Critical Temperature and \% Moles from GC Analysis
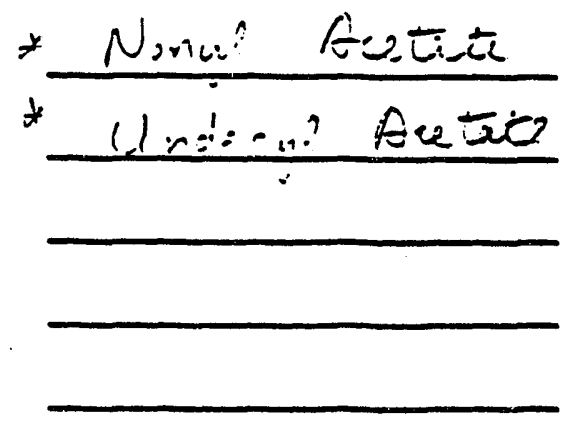

Remarks:
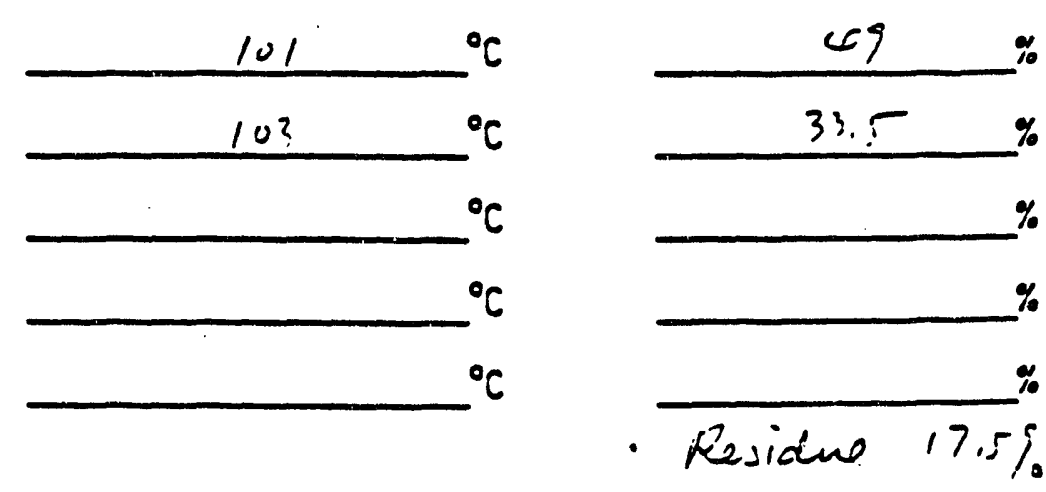

Time of Day Duration of Experiment Test Date

Test Performed By

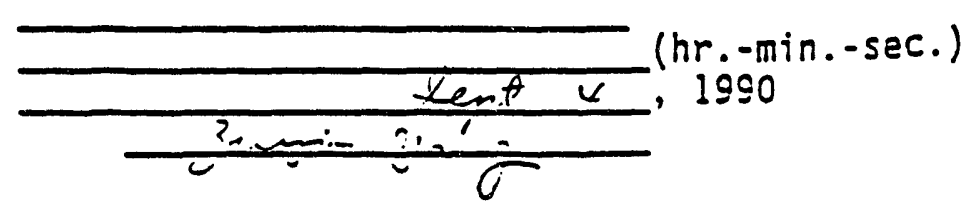


DATA ACCUMULATION SHEET

CHLORINATED SOLVENT SUBSTITUTION PROGRAM

SOLVENT RECYCLE/RECOVERY TASK

TEST CONDITIONS:

parameter $1 \mathrm{~mm} / \frac{1}{\mathrm{~g}}$

CONDITION \& T. P. Helices Packed Column, $500 \mathrm{ml}$ charge

Soivent Name De-Solve - It - Drisise-Ẽi

Distillation Procedure Simple Batch $x$ Extractive Azeotropic

Recovered Component, Critical Temperature and \% Moles from GC Analysjs

Oranaic ester Mineiral 0:1
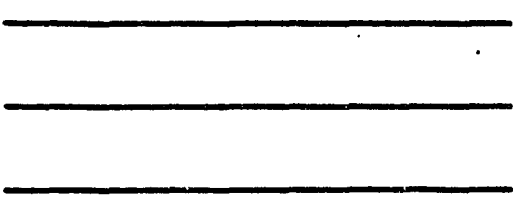

Remarks: The timperetiue at the tep of colvim chenges gradurlly.

Time of Day

Duration of Experiment

Test Date

Test Performed By
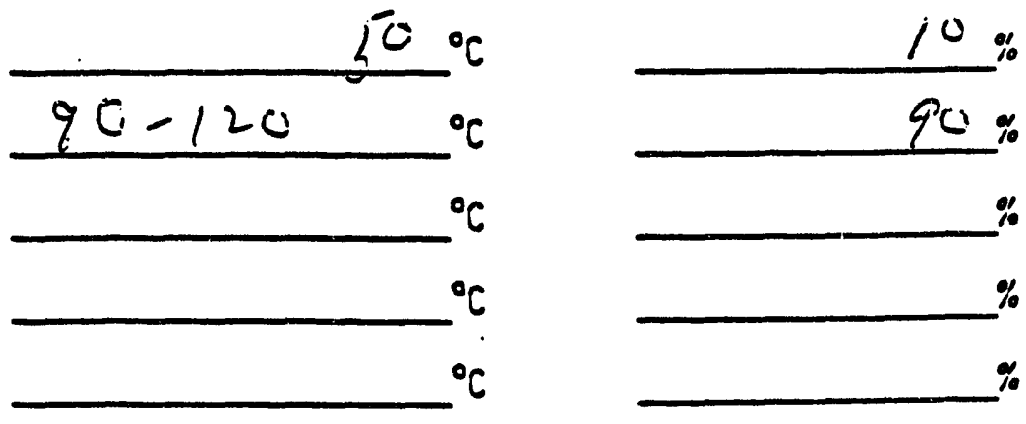
DATA ACCUMULATION SHEET

CHLORINATED SOLVENT SUBSTITUTION PROGRAM

SOLVENT RECYCLE/RECOVERY TASK

TEST CONDITIONS:

Parameter: $1 \mathrm{~mm} \mathrm{Hg}$

CONDITION : 8 T.F. Helices packed column. $500 \mathrm{ml}$. charged

Soivent Name Orange-Sol Co., De-Solve-It

Distillation Procedure Simple Batch $\mathrm{X}$ Extractive Azeotropic

Recovered Component, Critical Temperature and \% Moles from GC AnaTysis

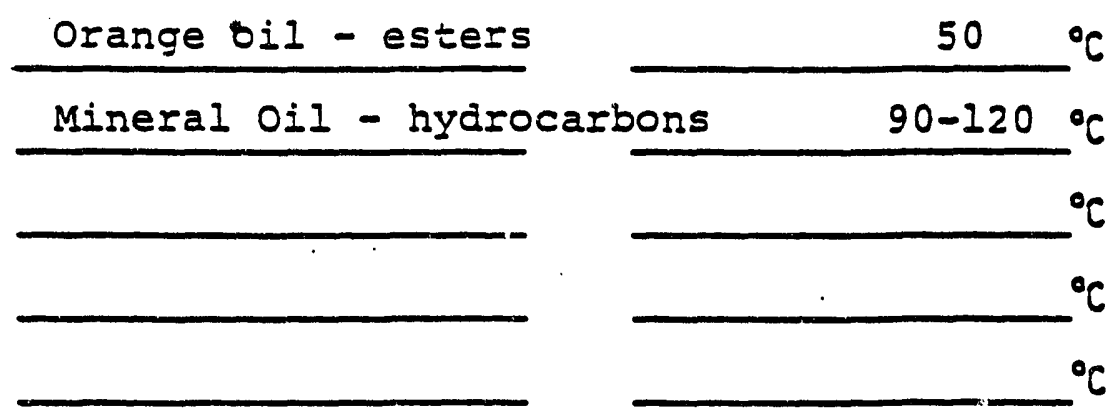

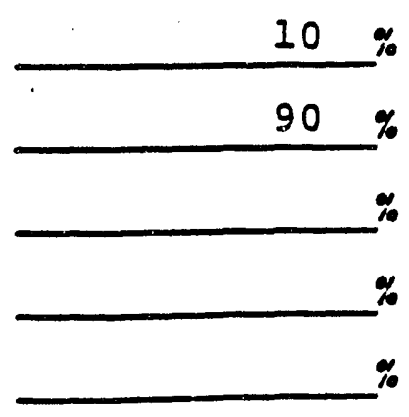

Remarks:

Time of Day

Duration of Experiment

Test Date

Test Performed By

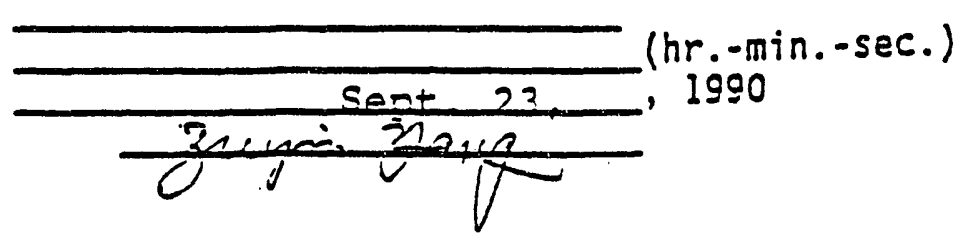




\section{DATA ACCUMULATION SHEET \\ CHLORINATED SOLVENT SUBSTITUTION PROGRAM}

SOLVENT RECYCLE/RECOVERY TASK

TEST CONDITIONS:

Parameter : $1 \mathrm{~mm}$ Hg.

CONDITION : 8 T.P. helices packed column, $700 \mathrm{ml}$.

Solvent Name 3-D Supreme

Distillation Procesure Simple Batch $\mathrm{X}$ Extractive Azsotropic

Recovered Component, Critical Temperature and \% Moies from GC Analysis
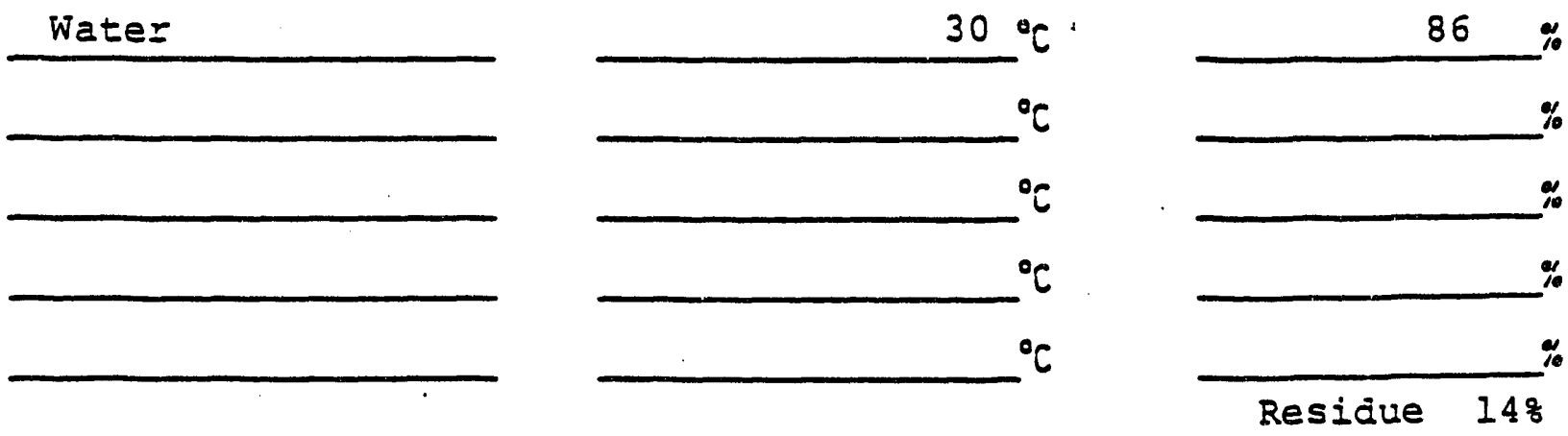

Remarks: Residue boils at very high temperature

Time of Day

Duration of Experiment Test Date

Test Periormed By

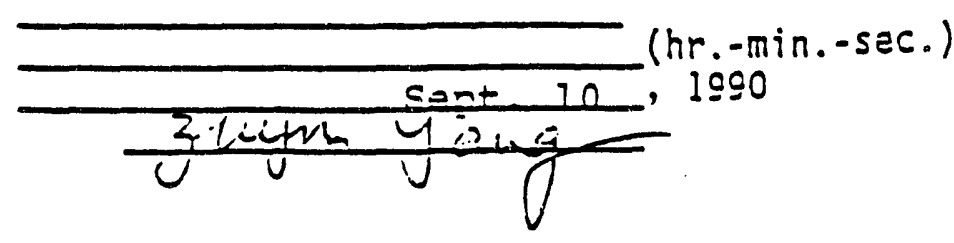

C-19 


\section{DATA ACCUMULATION SHEET \\ CHLORINATED SOLVENT SUBSTITUTION PROGRAM \\ SOLVENT RECYCLE/RECOVERY TASK}

TEST CONDITIONS:

Parameter : $1 \mathrm{~mm} \mathrm{Hg}$

CONDITION: 8 T.P. helices packed column, $400 \mathrm{mI}$. charge

Solvent Name SP-800 Chemical Solvents

Distillation Procedure Simple Batch Extractive Azeotropic

Recovered Component, Critical Temperature and \% Moles from GC Analysis
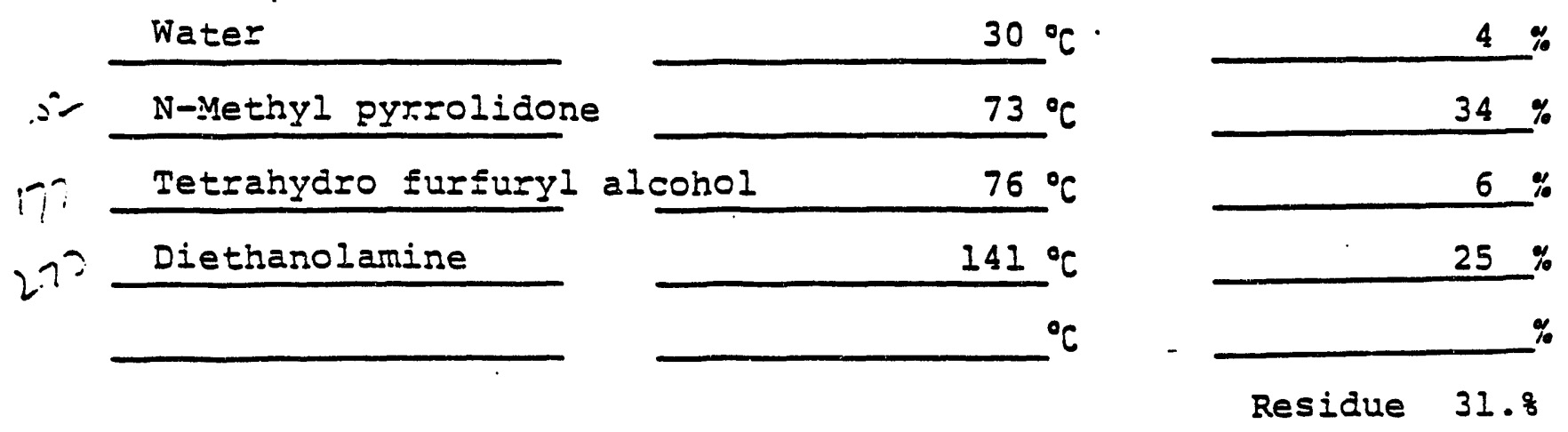

Remarks: The stillpot temperature exceeded $260^{\circ} \mathrm{C}$. I $1 \mathrm{~mm}$ Hg at end of run.

Time of Day

Duration of Experiment

Test Date

Test Performed by

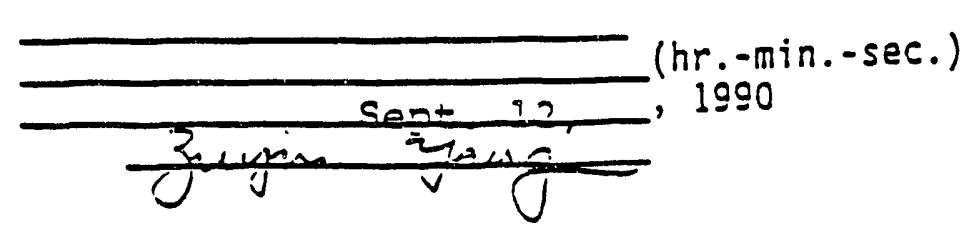


DATA ACCUMULATION SHEET

CHLORINATED SOLVENT SUBSTITUTION PROGRAM

SOLVENT RECYCLE/RECOVERY TASK

TEST CONDITIONS:

Parameter: $1 \mathrm{~mm}$. Hg

CONDITION : 8 T.P. helices Dacked column, $500 \mathrm{ml}$. charged

Solvent Name

Fine Organics, FO-606

Distillation Procedure Simple Batch X Extractive Azeotropic

Recovered Component, Critical Temperature and \% Moles from GC Analysis
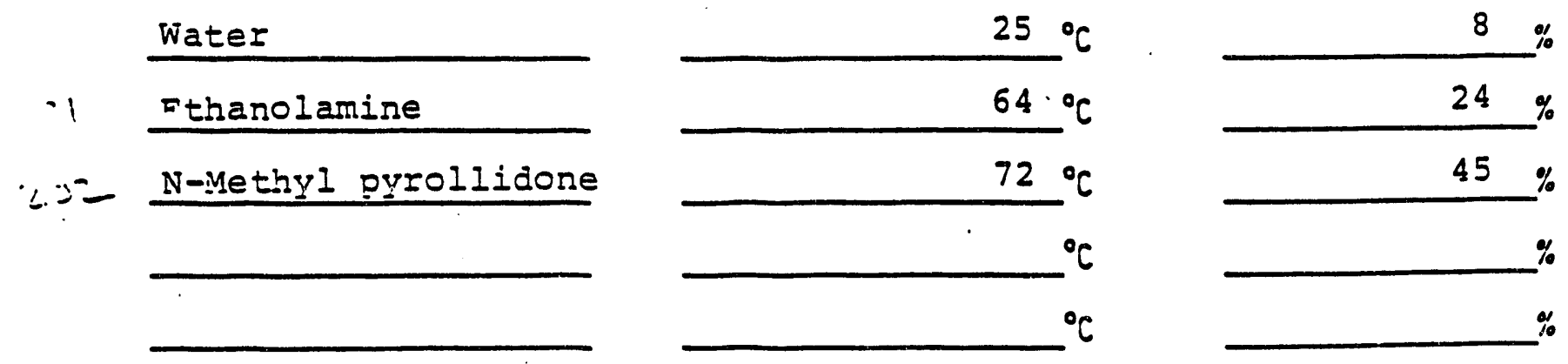

Remarks: Decomposition took place after $385 \mathrm{ml}$. had been removed from the $500 \mathrm{ml}$. charge-

Time of Day

Duration of Experiment

Test Date

Test Performed By

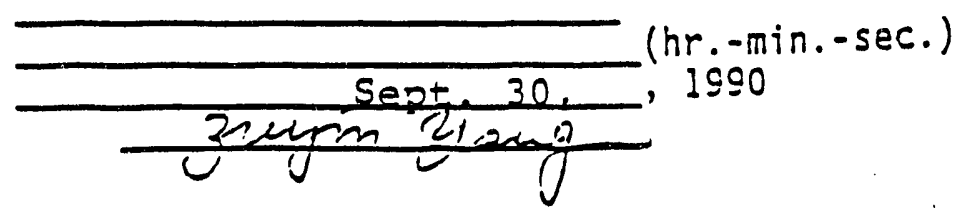


DATA ACCUMULATION SHEET

CHLORINATED SOLVENT SUBSTITUTION PROGRAM

SOLVENT RECYCLE/RECOVERY TASK

TEST CONDITIONS:

Parametar: $1 \mathrm{~mm} \mathrm{Hg}$

CONDITION : 8 T.P. helices packed column, $400 \mathrm{ml}$. charged

Solvent Name

Fred. Gumm Co.

Distillation Procedure Simple Batch $\mathrm{x}$ Extractive Azeotropic

Recovered Component, Critical Temperature and \% Moles from GC Analysis
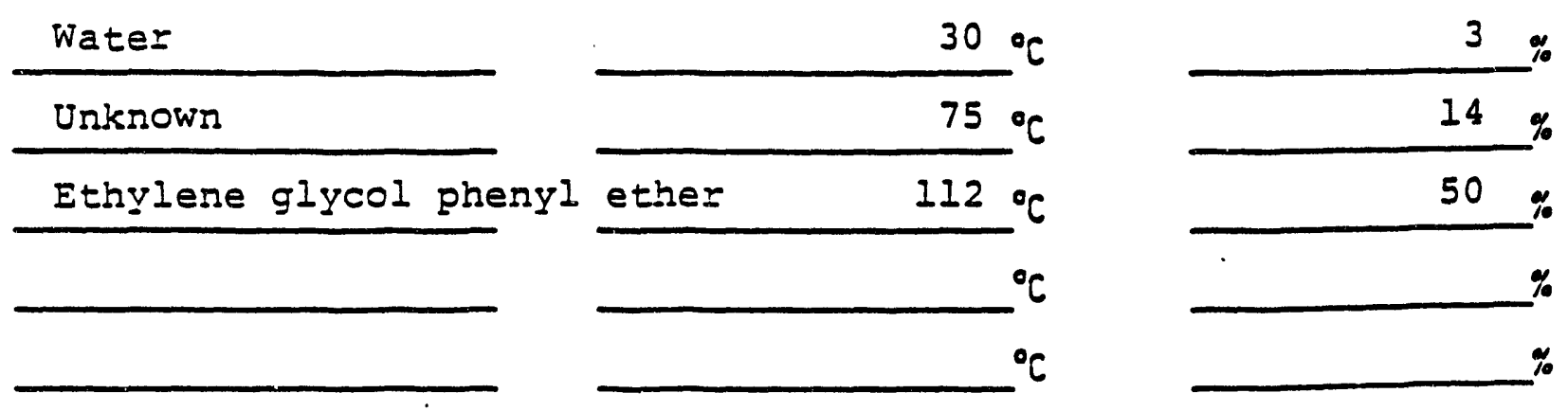

Remarks: Decomposition takes place after $265 \mathrm{ml}$. taken off.

Time of Day

Duration of Experiment

Test Date

Test Performed By

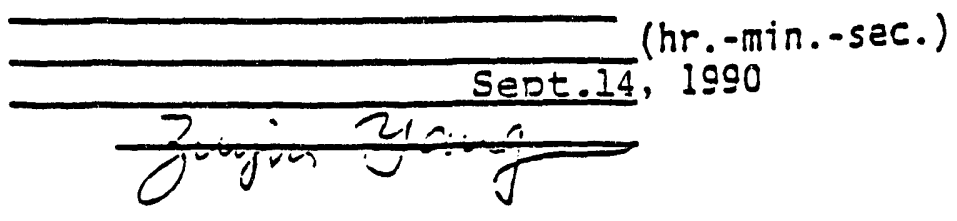


DATA ACCUMULATION SHEET

\section{CHLORINATED SOLVENT SUBSTITUTION PROGRAM}

SOLVENT RECYCLE/RECOVERY TASK

TEST CONDITIONS:

\section{Perameter}

I muth

Solvent Name
CONDITION

1. Locidity with perimectifips

Distillation Procedure Simpie Batch $X$ Extractive Azeotropic

Recovered Component, Critical Temperature and \% Moles from GC Analysis

A- Methil puilrolidene
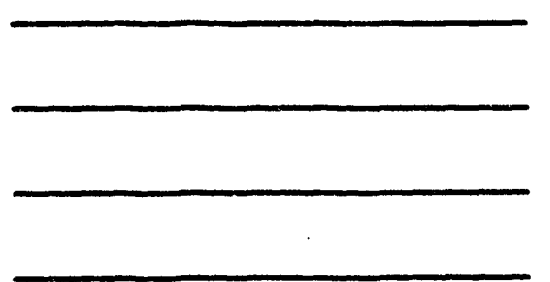

Remarks:
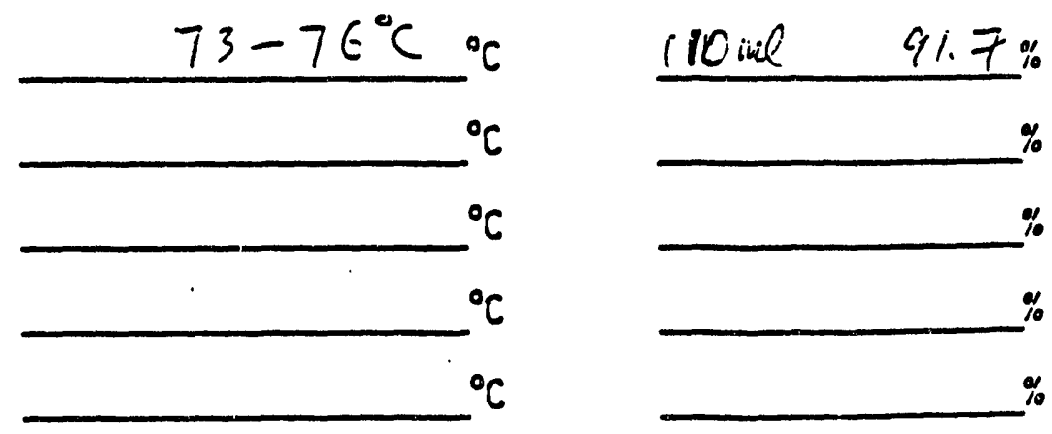

Time of Day

Duration of Experiment

Test Date

Test Performed By

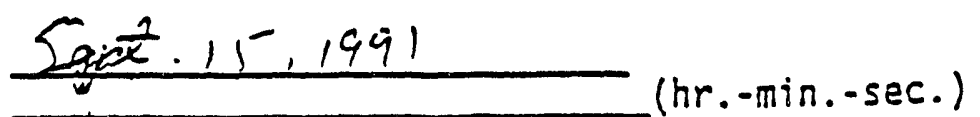

sint is, 15al, 1990 


\section{DATA ACCUMULATION SHEET}

CHLORINATED SOLVENT SUBSTITUTION PROGRAM

SOLVENT RECYCLE/RECOVERY TASK

TESTPCONDITIONS:

\section{Parametar}

CONDITION

$600 \mathrm{mntg}$, of Nheore plata.s

Soivent Name $\quad$ GAF M-Pirol $500 \mathrm{~cm}-\mathrm{C}$ New matevial

Distiliation Procedure Simple Batch $X \quad$ Extractive Azeotropic

Recovered Component, Critical Temperature and \% Moles from GC Analysis

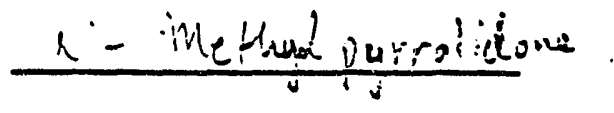

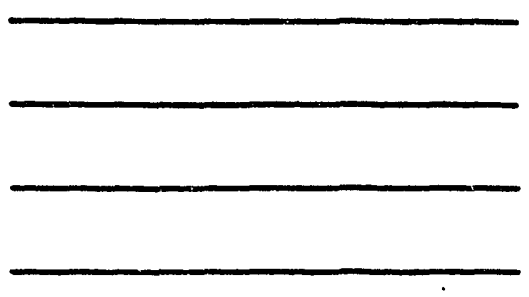

Remarks:

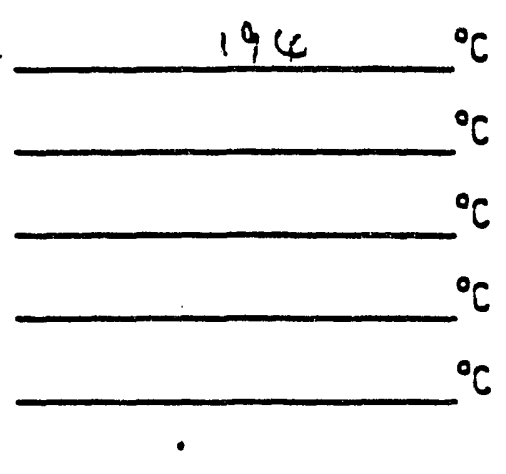

Time of Day

Duration of Experiment

Test Date

Test Performed By

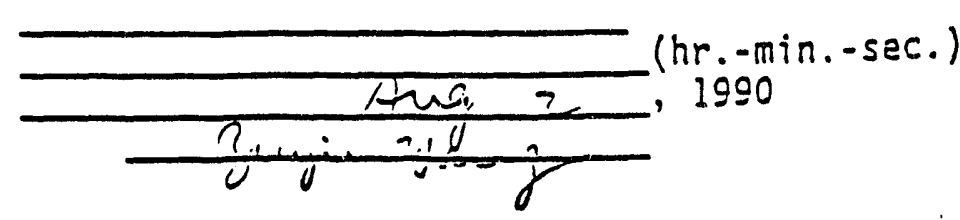


DATA ACCUMULATION SHEET

CHLORINATED SOLVENT SUBSTITUTION PROGRAM

SOLVENT RECYCLE/RECOVERY TASK

TEET CONDITIONS:

\section{Parameter}

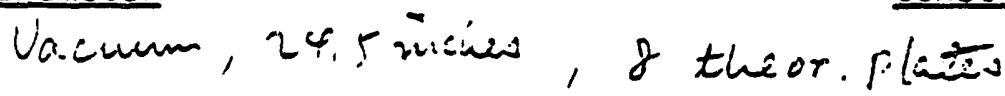

Soivent Neme 4oond Patelin

Distillation Procedure Simple Batch $X$ Extractive Azeotropic

Recovered Component, Critical Temperature and \% Moles from GC Analysis

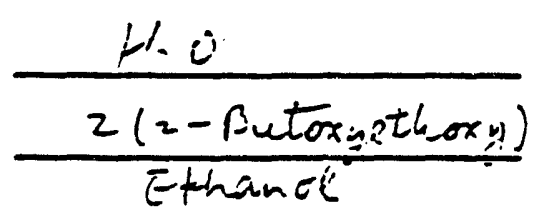

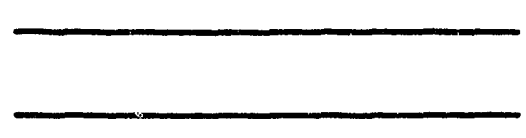

Remarks : (uncurrected) $30^{\circ} \mathrm{C}{ }^{\circ} \mathrm{C}$

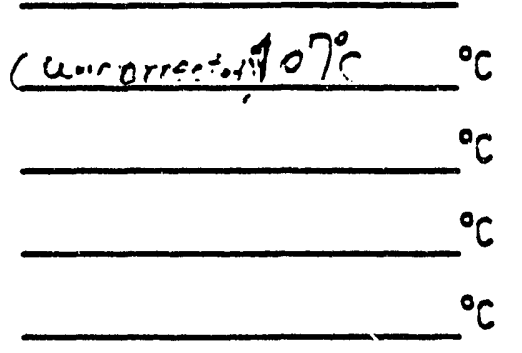

$20 \%$

$51.3 \%$
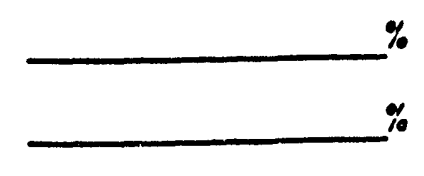

Re-ián $28.75 \%$

Time of Day

Duration of Experiment

Test Date

Test Performed By

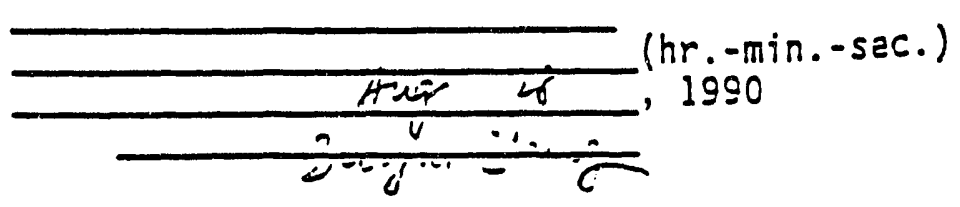


DATA ACCUMULATION SHEET

CHLORINATED SOLVENT SUBSTITUTION PROGRAM

SOLVENT RECYCLE/RECOVERY TASK

TEST CONDITIONS:

Parameter

1 milig

Solvent Name

\section{CONDITION}

1. LeAOING WITH PAINT CHIPS

2. SIMPLE DISTILLATION.

Distillation Procedure Simple Batch $x$ Extractive Azeotropic

Recovered Component, Critical Temperature and \% Moles from GC Analysis
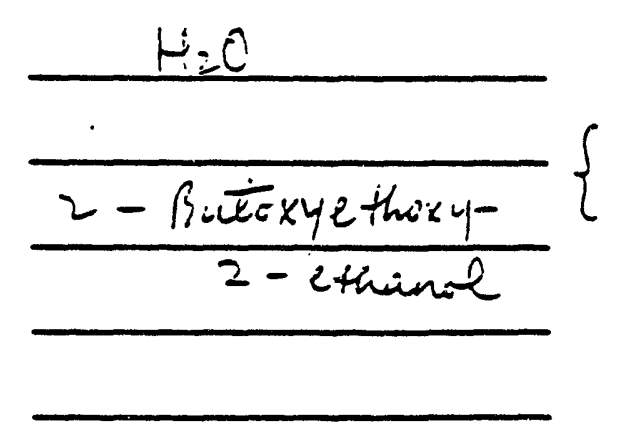

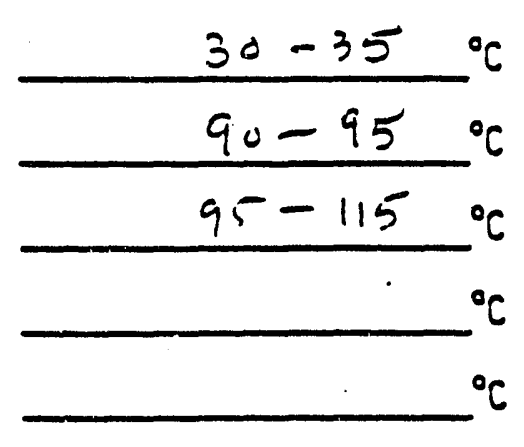

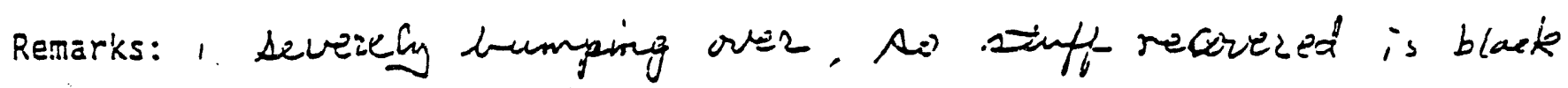
liquid

2. The amounis of stuff looding wist $120 \mathrm{ml}$

Time of Day

Duration of Experiment

Test Date

Test Performed By

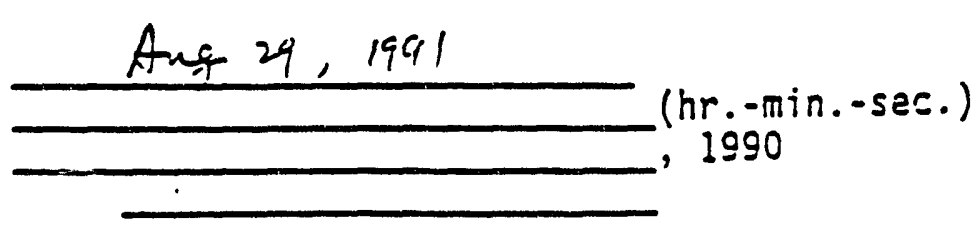




\section{- \& \\ DATA ACCUPHULATION SHEET \\ CHLORINATED SOLVENT SUBSTITUTION PROGRAM \\ SOLVENT RECYCLE/RECOVERY TASK}

TEST CONDITIONS:

$\frac{\text { Parameter }}{1 \text { mm Hz }}$

Soivent Name

CONDITION

1. Loceding with painichips

2 . Simple Diztilliction

Distillation Procedure Simple Batch $X$ Extractive Azeotropic

Recovered Component, Critical Temperature and \% Moles from GC Analysis Benaul alcokel + Clnkiown
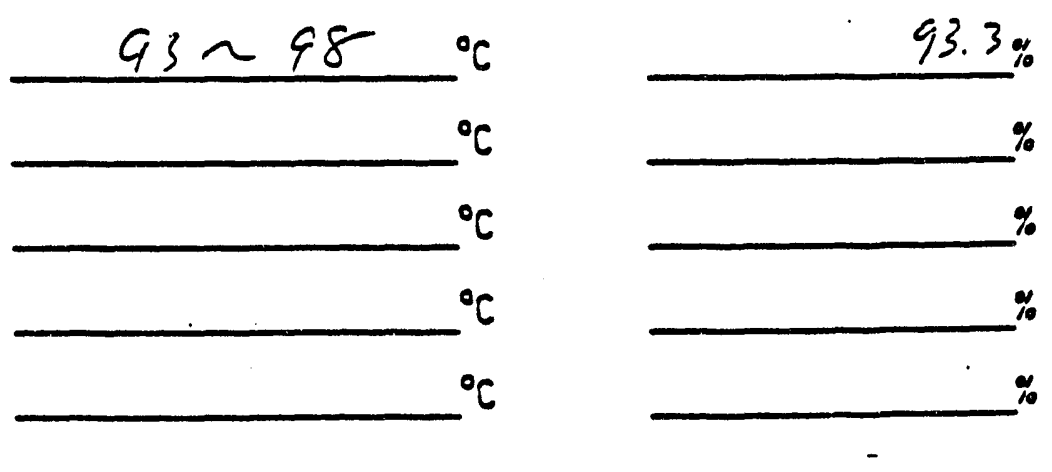

Remarks :

Time of Day

Duration of Experiment Test Date

Test Performed By

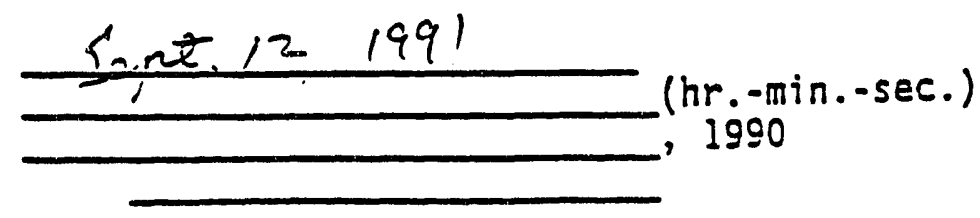


DATA ACCUMULATION SHEET

CHLORINATED SOLVENT SUBSTITUTION PROGRAM

SOLVENT RECYCLE/RECOVERY TASK

TEST CONDITIONS:

\section{Parameter}

640mmbe, 8 theor piates

Soivent Name Cee Bee $A 24560 \mathrm{ml}$

Distillation Procedure Simple Batch $X$ Extractive __ Azeotropic

Recovered Component, Critical Temperature and \% Moles from GC Analysis
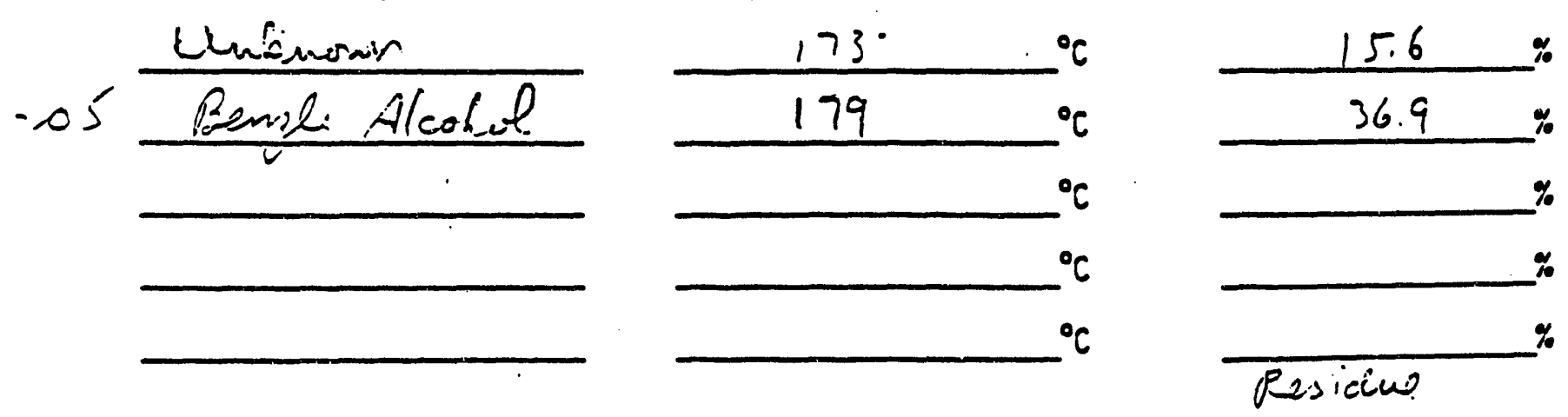

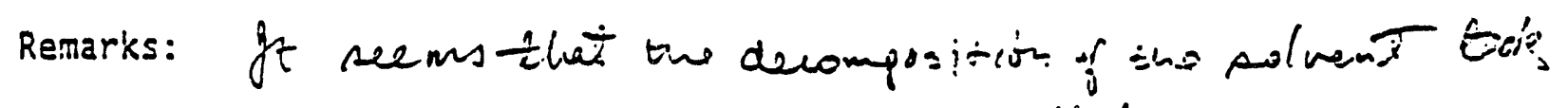
place. gt needs to ba dirtilled under rascucum. jisssure

Time of Day

Duration of Experiment

Test Date

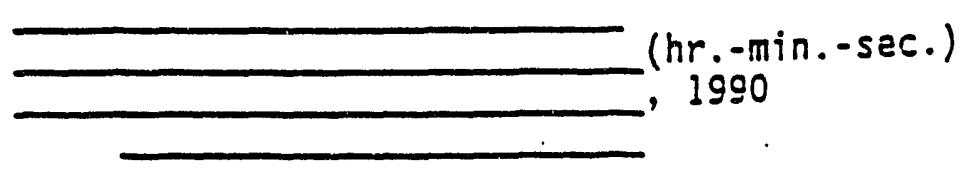

Test Performed By 


\section{DATA ACCUMULATION SHEET}

CHLORINATED SOLVENT SUBSTITUTION PROGRAM

SOLVENT RECYCLE/RECOVERY TASK

TEST CONDITIONS:

Parameter

CONDITION

Vacuum 24,5 incies

$$
a^{2} \text { Theore: Flates }
$$

Solvent Name Le E2 fo 205

Distillation Procedure Simple Batch ./ Extractive Azeotropic

Recovered Component, Critical Temperature and \% Moles from GC Analysis

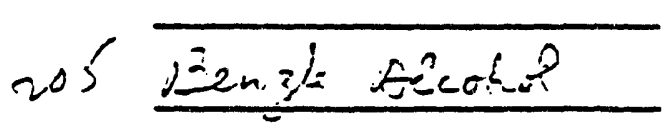

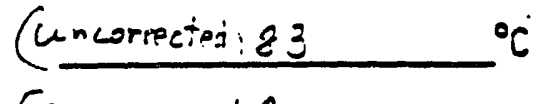

Cuncersestigo $\quad{ }^{\circ} \mathrm{C}$

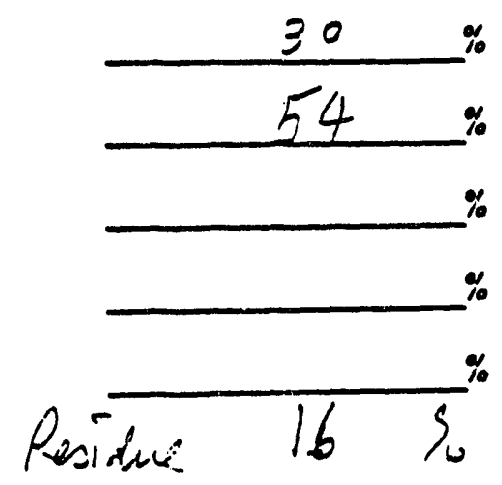

Remarks:

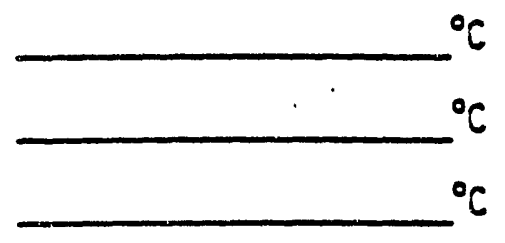

Pesidue $16 \%$

Time of Day

Duration of Experiment

Test Date

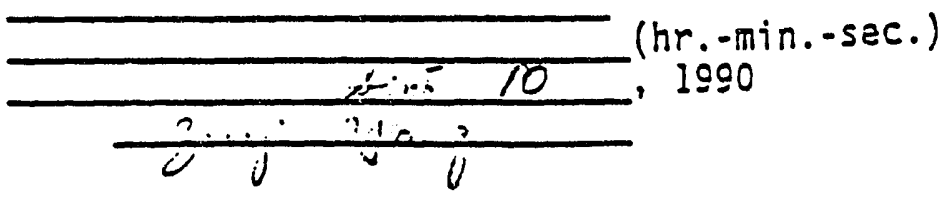

Test Performed By 


\section{DATA ACCUMULATION SHEET \\ CHLORINATED SOLVENT SUBSTITUTION PROGRAM \\ SOLVENT RECYCLE/RECOVERY TASK}

TEST CONDITIONS:

Parameter

Gllo nom Hig.

Solvent Name
Cet $F_{22} \in[77$ (400 ml)

Distiliation Procedure Simple Batch $X$ Extractive Azeotropic

Recovered Component, Critical Temperature and \% Moles from GC Analysis

Etinanifamine

umberigenn
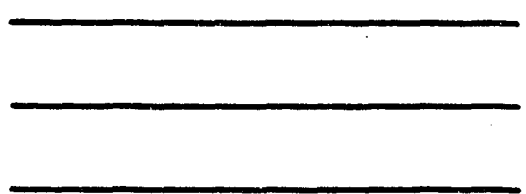

Remarks:

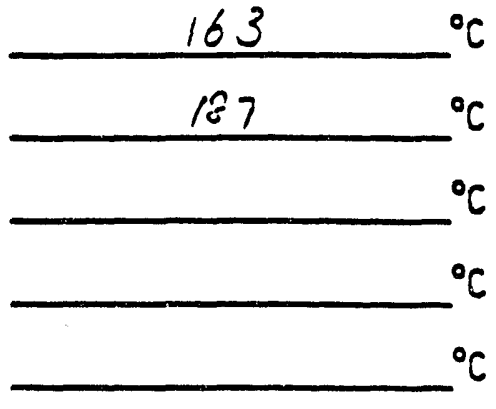

$50 \%$ $16.3 \%$
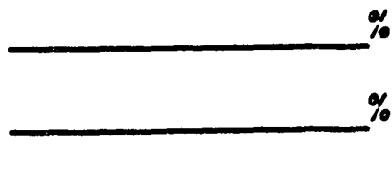

Ruiaue $33.7 \%$.
Time of Day

Duration of Experiment

Test Date

Test Performed By

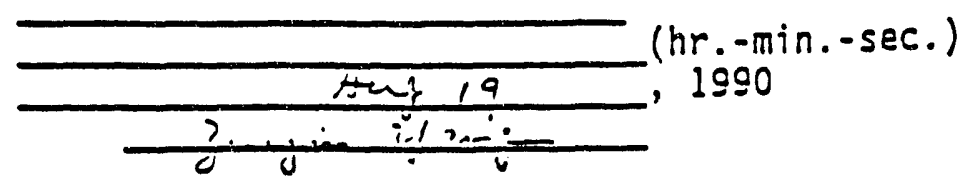

C-30 


\section{DATA ACCUMULATION SHEET \\ CHLORINATED SOLVENT SUBSTITUTION PROGRAM \\ SOLVENT RECYCLE/RECOVERY TASK}

TEST CONDITIONS:

Parameter

Vacuun, L4. Tinches

CONDITION

Solvent Name L.0. $m l$

Distillation Procedure Simple Batch $x$ Extractive Azeotropic

Recovered Component, Critical Temperature and \% Moles from GC Analysis

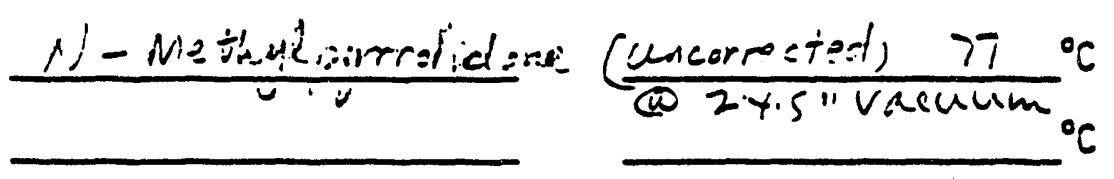

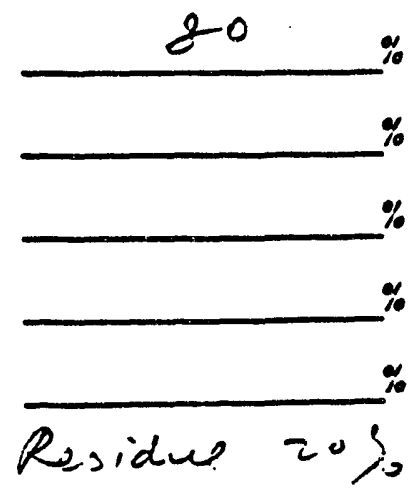

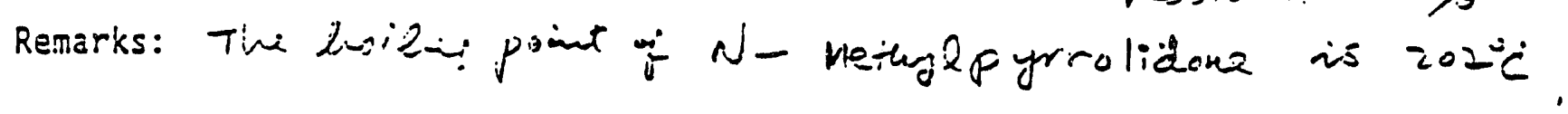

Time of Day Duration of Experiment Test Date Test Performed By

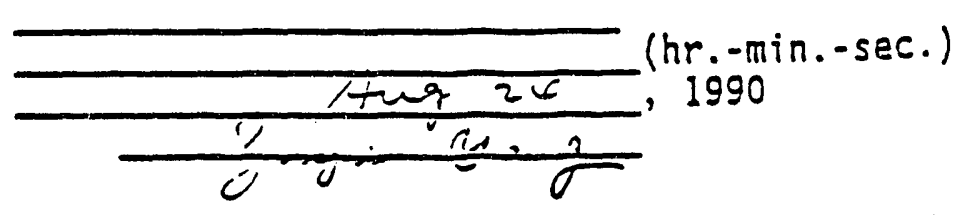




\section{DATA ACCUMULATION SHEET \\ CHLORINATED SOLVENT SUBSTITUTION PROGRAM \\ SOLVENT RECYCLE/RECOVERY TASK}

TEST CONDITIONS:

Päameter CONDITION

Vacuum 24.5 inches, o theor platis

Solvent Name $T-5668$ (Teiren) $400: \mathrm{m}$.

Distillation Procedure Simple Batch \# Extractive ___ Azeotropic

Recovered Component, Critical Temperature and \% Moles from GC Analysis

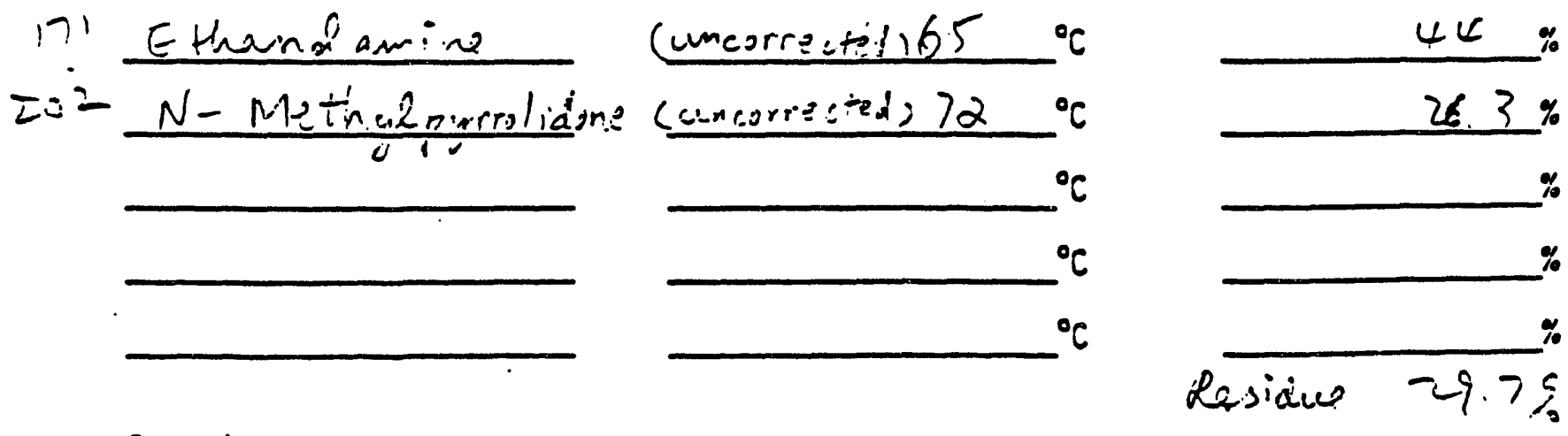

Remarks:

Time of Day

Duration of Experiment

Test Date

Test Performed By

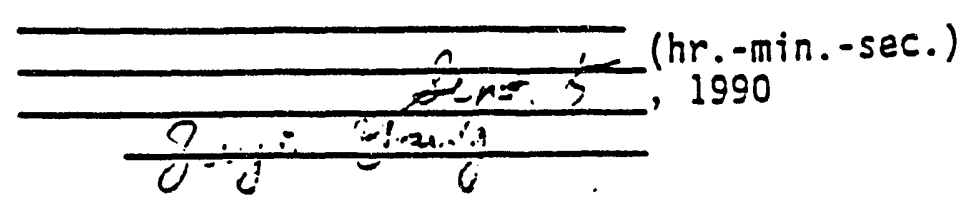


DATA ACCUMULATION SHEET

CHLORINATED SOLVENT SUBSTITUTION PROGRAM

SOLVENT RECYCLE/RECOVERY TASK

TEST CONDITIONS:

Parametar

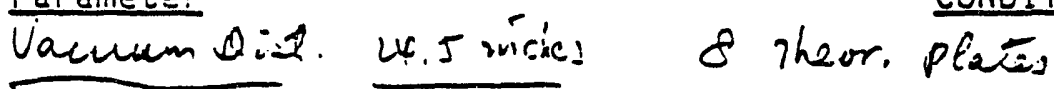

Solyent Name H l4o Saf-Sols (Eid-Tek) 400m?

Distillation Procedure Simple Batch $x$ Extractive Azeotropic

Recovered Component, Critical Temperature and \% Moles from GC AnaTysis

$\frac{\text { Cetal } a_{\text {cetat }}}{\text { O-tad2 }=n \text { ? } a_{12 t a-2}}$

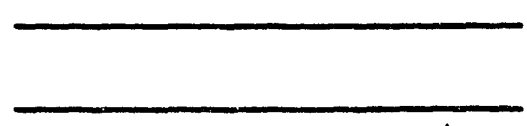

Remarks:
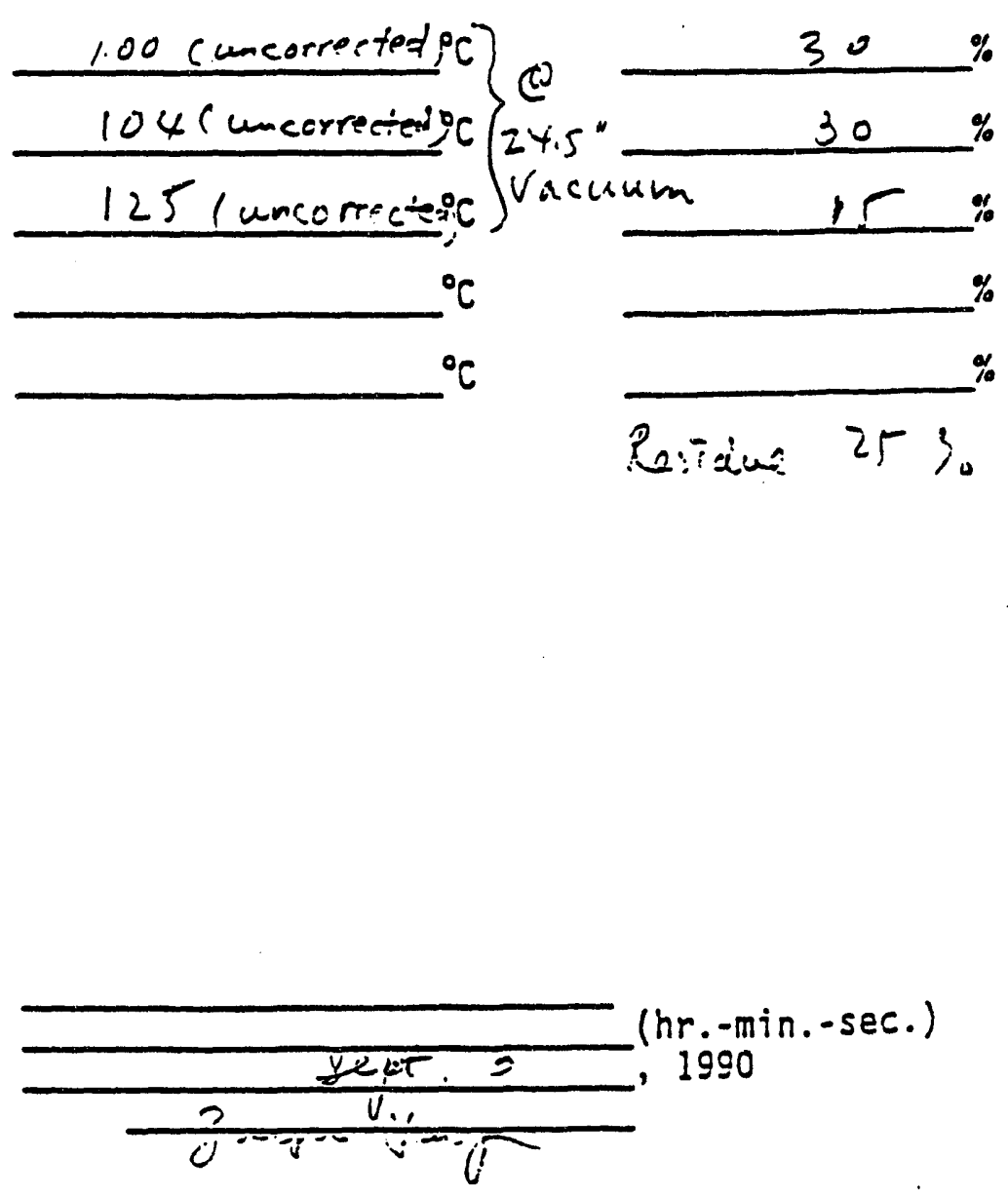

C-33
Time of Day

Duration of Experiment Test Date

Test Performed By 
Appendix 2 - Distillation Results, Used Solvents

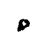




\section{DATA ACCUMULATION SHEET \\ CHLORINATED SOLVENT SUBSTITUTION PROGRAM \\ SOLVENT RECYCLE/RECOVERY TASK}

TEST CONDITIONS:

Parameter: $1 \mathrm{~mm}$. Hg

CONDITION : 8 T.P. helices packed column, $500 \mathrm{ml}$. charged

Solvent Name

Fine Organics, F0-606

Distillation Procedure Simple Batch $\mathrm{X}$ Extractive Azeotropic

Recovered Component, Critical Temperature and \% Moles from GC Analysis
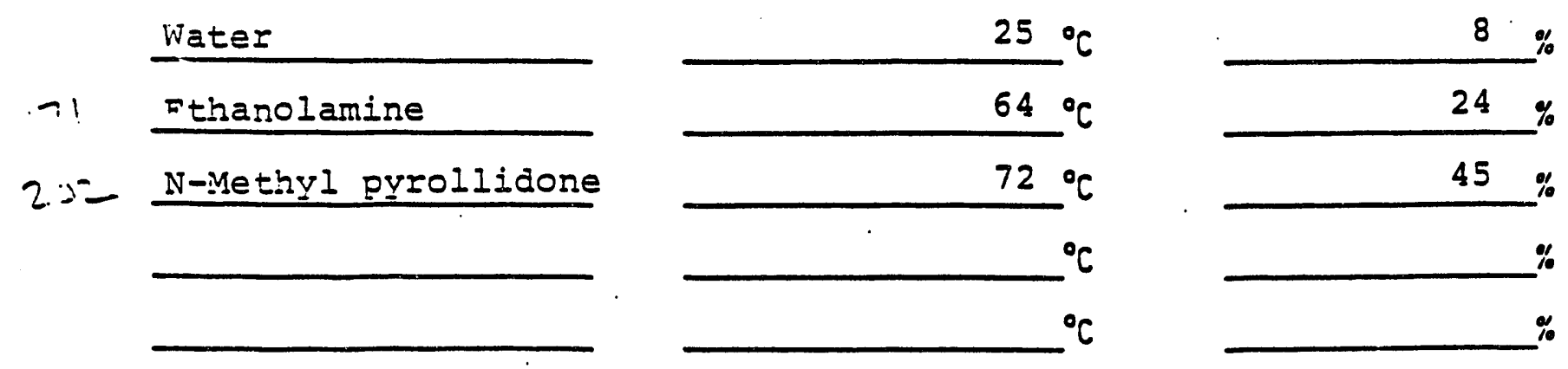

Remarks: Decomposition took place after $385 \mathrm{ml}$. had been removed from the $500 \mathrm{ml}$. Charge-

Time of Day

Duration of Experiment Test Date

Test Performed By

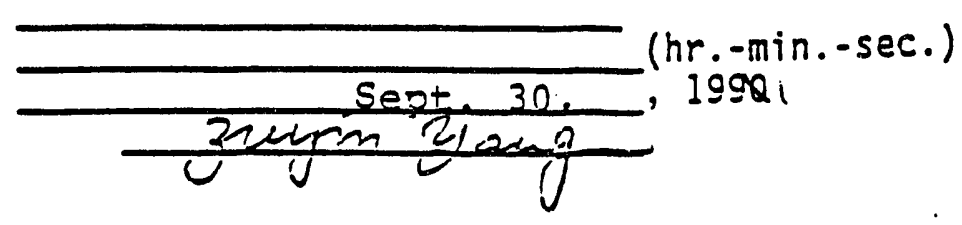


Figure 3.

DATA ACCUMULATION SHEET

CHLORINATED SOLVENT SUBSTITUTION

DISTILLATION

SOLVENT RECYCLE/RECOVERY

Soivent Name CEPO ENVIROSTRIP 222

Soivent Soil

Distillation Procadure: Simple Batch $x$ Extractive

Azeotropic

Test Conditions:

Parameter

I mo Hg preasuce

Recovered Component

unknown

\section{Condition}

:

8 theoreizical plate

helices packer colcum

Critical Temperature $\left({ }^{\circ} \mathrm{C}\right)$ \% Moles

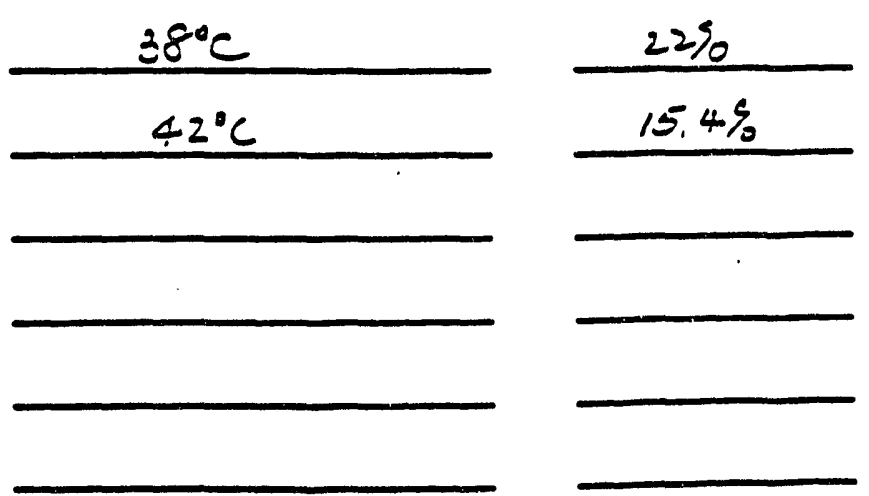

REIARXS: Analysis by GC unTess otherwise noted;

sample from $5 \mathrm{ml}$ distilles to $81 \mathrm{ml}$ distillate

Refractive Index: 1.4255 1.442.

sample from $100 \mathrm{wl} \sim 187 \mathrm{ml}$ Refractice Index: 1.5125-1.536

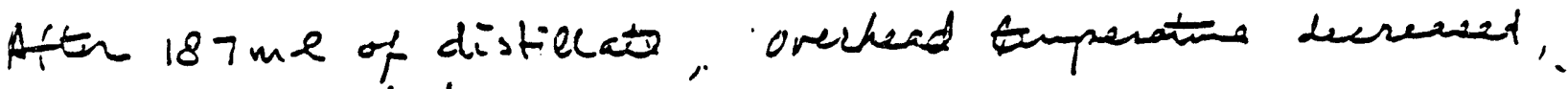
decompsition ivek place.

Date and Time of Test:

$6-14-91$

Test Performed by:

Zumi Jang 
DATA ACCUMULATION SHEFT

CHLORINATED SOLVENT SUBSTITUTION PROGRAM

SOLVENT RECYCLE/RECOVERY TASK

TEST CONDITIONS:

Parameter

$1 \mathrm{mmHg}$

Solvent Name

\section{CONDITION}

1. LoHOING WITH PAINT. CHIPS

2. SIMPLE DISTILLATION

Distillation Procedure Simple Batch $\subset$ Extractive Azeotropic

Recovered Component, Critical Temperature and \% Moles from GC Analysis
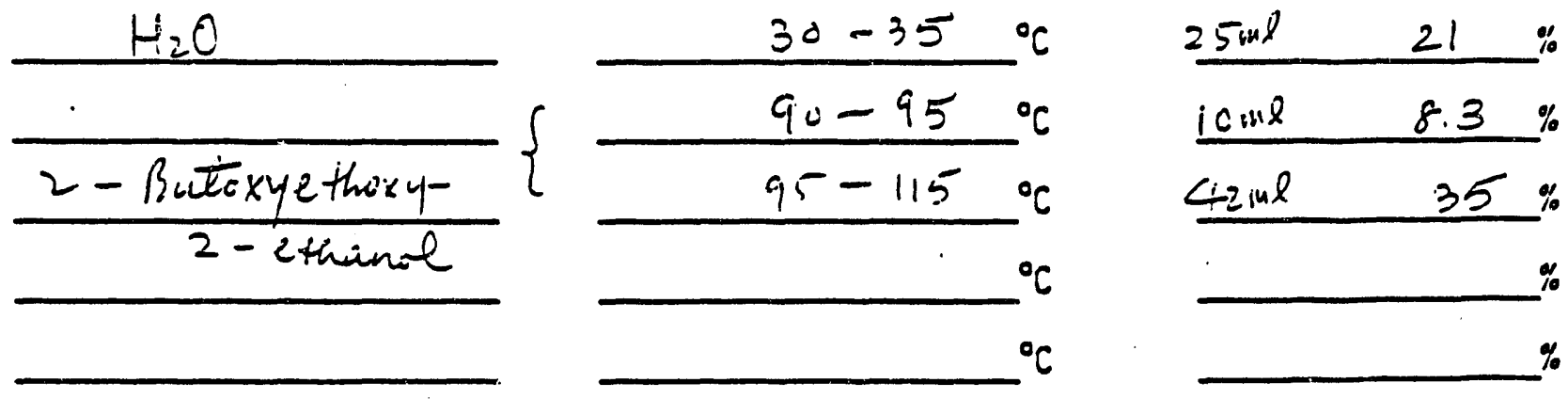

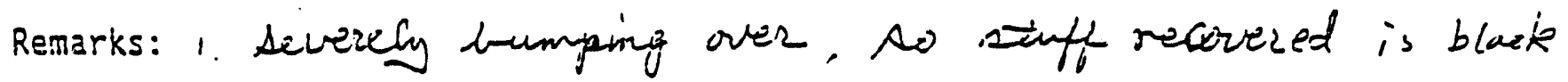
liquid

2. The amount of stiff locoling was t.20 ml

Time of Day

Duration of Experiment

Test Date

Test Performed By
Ang 29, 1991

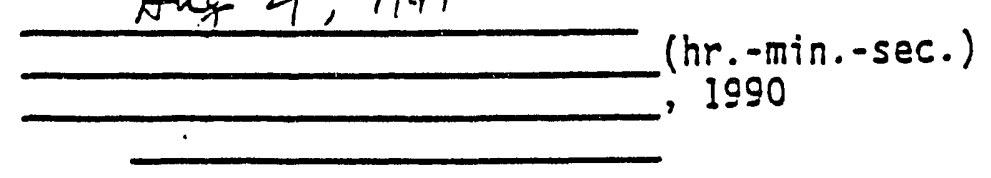




\section{a. $\cdot$ \\ DATA ACCUPULATION SHEET \\ CHLORINATED SOLVENT SUBSTITUTION PROGRAM \\ SOLVENT RECYCLE/RECOVERY TASK}

TEST CONDITIONS:
Parameter
CONDITION
I min Hg-
Solvent Name
1. LOADINGT WITH PAINT CHIPS
TURCO T- 5668
2. SIMPLE SASTILLATION

Distillation Procedure Simple Batch $X$ Extractive Azeotropic

Recovered Component, Critical Temperature and \% Moles from GC Analysis

Ethanclamine N-Methul purrolidone
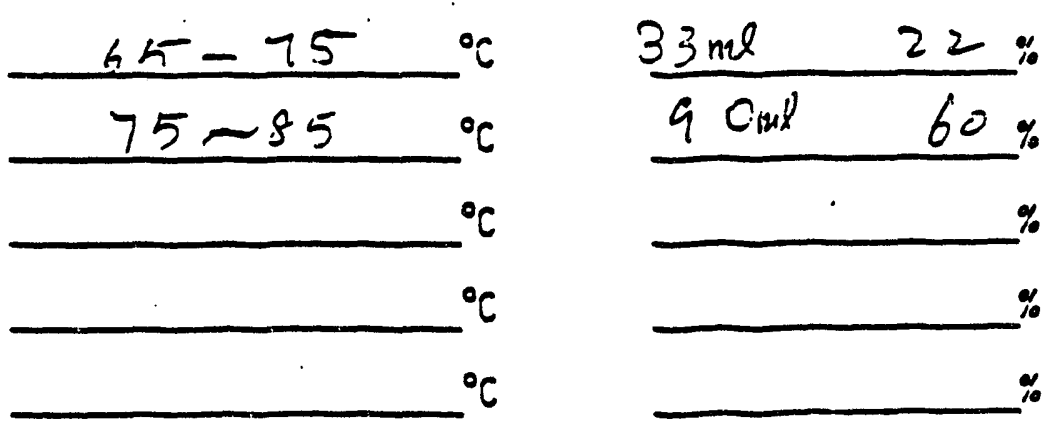

Remarks: of lower layer from

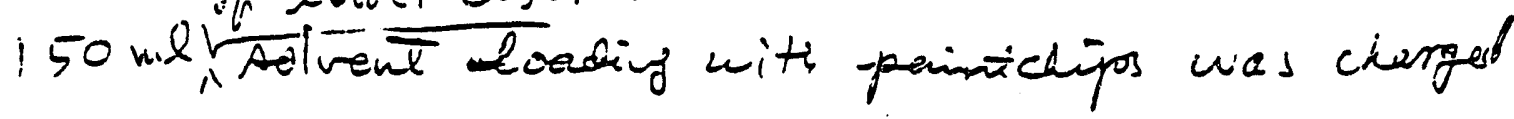
in the still.

Time of Day

Duration of Experiment Test Date

Test Periormed By

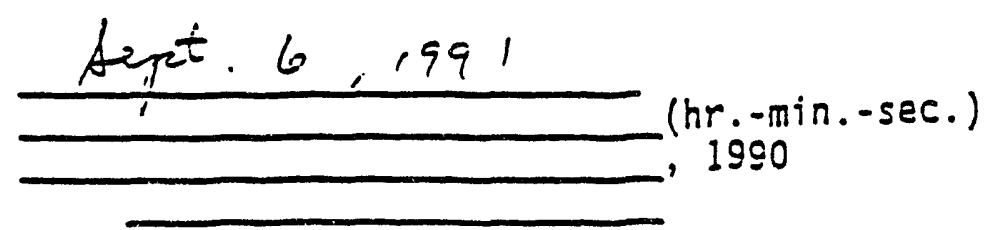


DATA ACCUMULATION SHEET

CHLORINATED SOLVENT SUBSTITUTION PROGRAM

SOLVENT RECYCLE/RECOVERY TASK

\section{TEST CONDITIONS:}

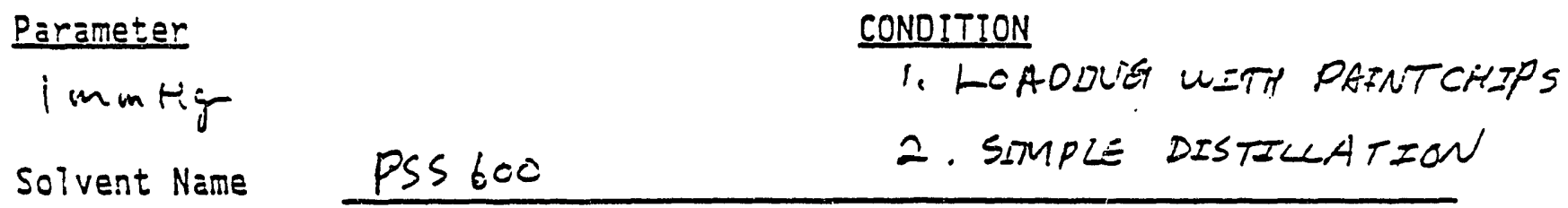

Distillation Procedure Simple Batch $y$ Extractive Azeotropic

Recovered Component, Critical. Temperature and \% Moles from GC Analysis

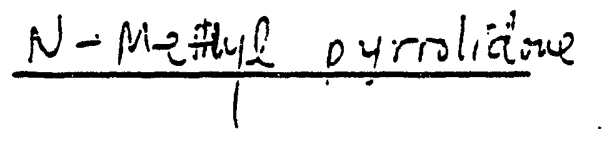
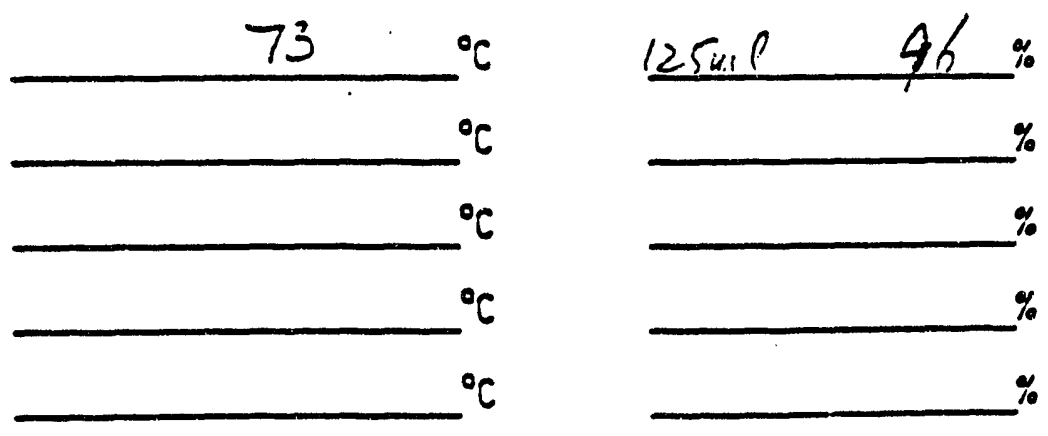

Remarks:

It sezirs to be a puare componad

Time of Day

Duration of Experimeit

Test Date

Test Performed By

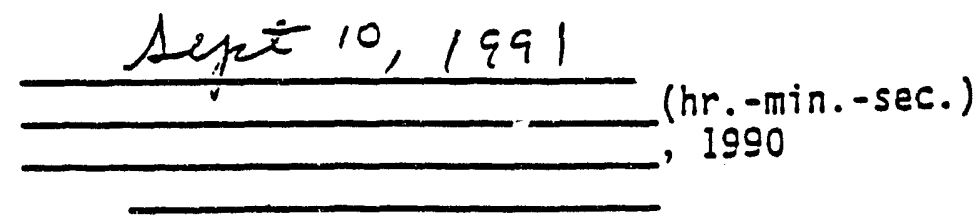




\section{$2 \pi$ \\ DATA ACCUMULATION SHEET \\ CHLORINATED SOLVENT SUBSTITUTION PROGRAM \\ SOLVENT RECYCLE/RECOVERY TASK.}

TEST CONDITIONS:

Päameter

$1 \mathrm{minHz}$

Solvent Name CEE BÉ A-205

CONOITION

1. Loceding with fainichips

2 . Simple Distilliction

Distiliation Procedure Simple Batch $X$ Extractive Azeotropic

Recovered Component, Critical Temperature and \% Moles from GC Analysis Eenzul alcohe + Clnkizowin

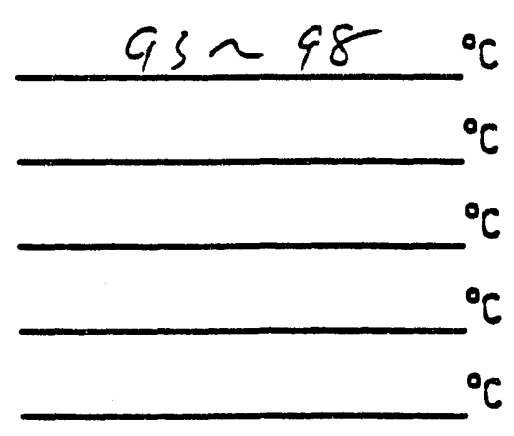
$93.3 \%$
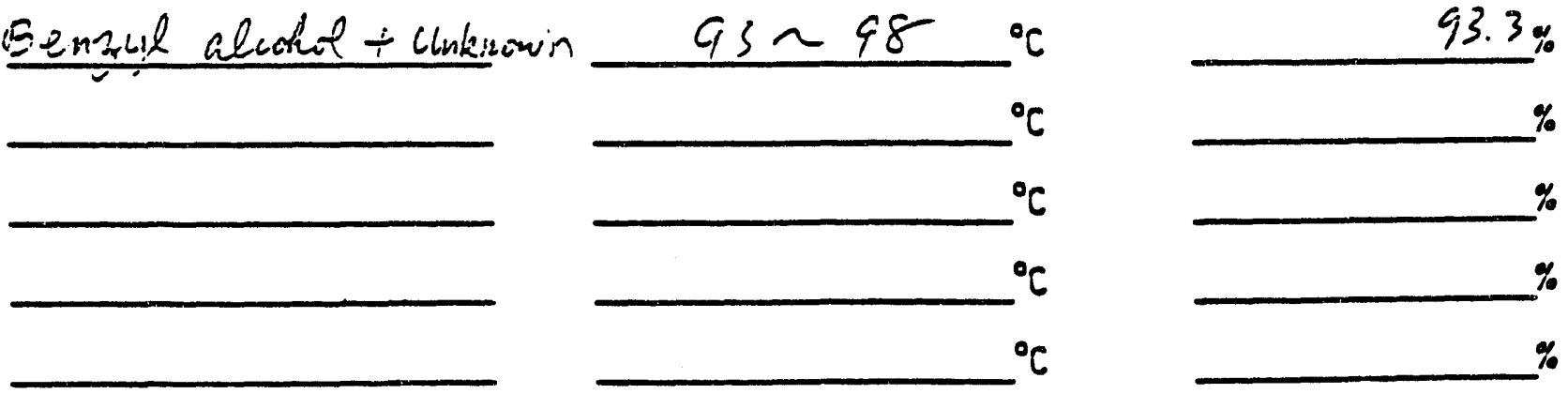

Remarks:

Time of Day

Duration of Experiment

Test Dite

Sant 12,1991

Test Periormed By

.-min.-sec.)

1990 


\section{DATA ACCUMULATION SHEEI}

CHLORINATED SOLVENT SUBSTITUTION PROGRAM

SOLVENT RECYCLE/RECOVERY TASK

\section{TEST CONDITIONS:}

\section{Parameter}

I unteg

Solvent Name
CONDITION

1. Locidity with preiniclifips

x. Singe toisillation Distillation Procedure Simple Batch $X$ Extractive Azeotropic

Recovered Component, Critical Temperature and \% Moles from GC Analysis

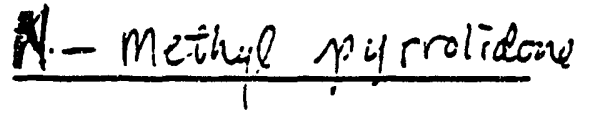

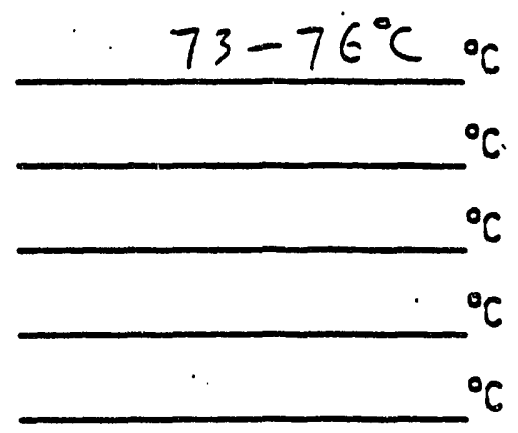

110 inl $91.7 \%$

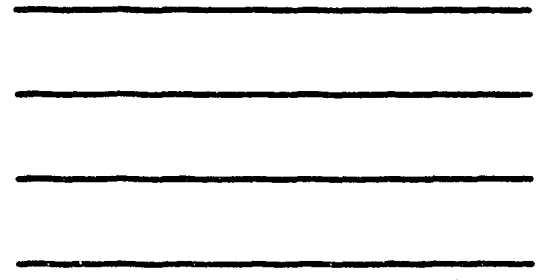
GAF $\dot{m}-P_{4} \dot{R}$

Remarks:

Time of Day

Duration of Experiment Test Date

Test Performed By

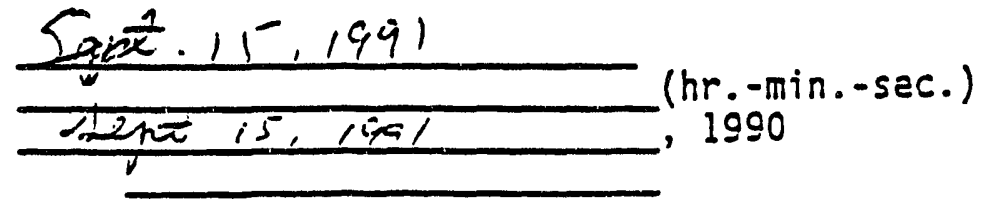




\section{$+4$}

DATA ACCUMULATION SHEET

CHLORINATED SOLVENT SUBSTITUTION PROGRAM

SOLVENT RECYCLE/RECOVERY TASK

TEST CONDITIONS:

Parameter

Gle mim Hy

Solvent Name

\section{CONDITION}

8 Theor. placis.

Cee His $\& 477(400 \mathrm{ml})$

Distillation Procedure Simple Batch $X$ Extractive Azeotropic

Recovered Component, Critical Temperature and \% Moles from GC Analysis
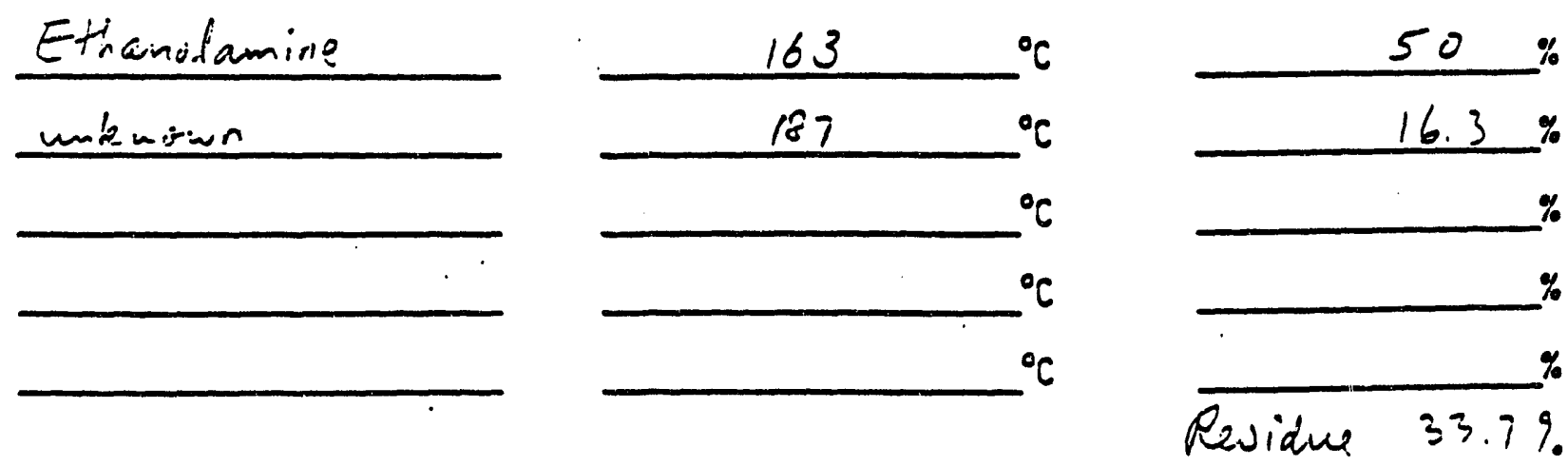

Remarks:

Time of Day

Duration of Experiment Test Date

Test Performed By

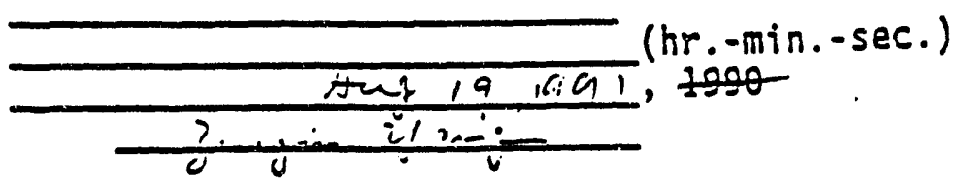




\section{Appendix D}

\section{Economic Analysis of 1 Plant Versus 5 Plants}


D-2 


\title{
RECOVERY OF M-PYROL SPENT SOLVENT
}

\author{
ECONOMIC ANALYSIS OF
}

1 PLANT VERSUS 5 PLANTS

WRITTEN BY: CHARMIN PETERSEN

MAY 5, 1992 


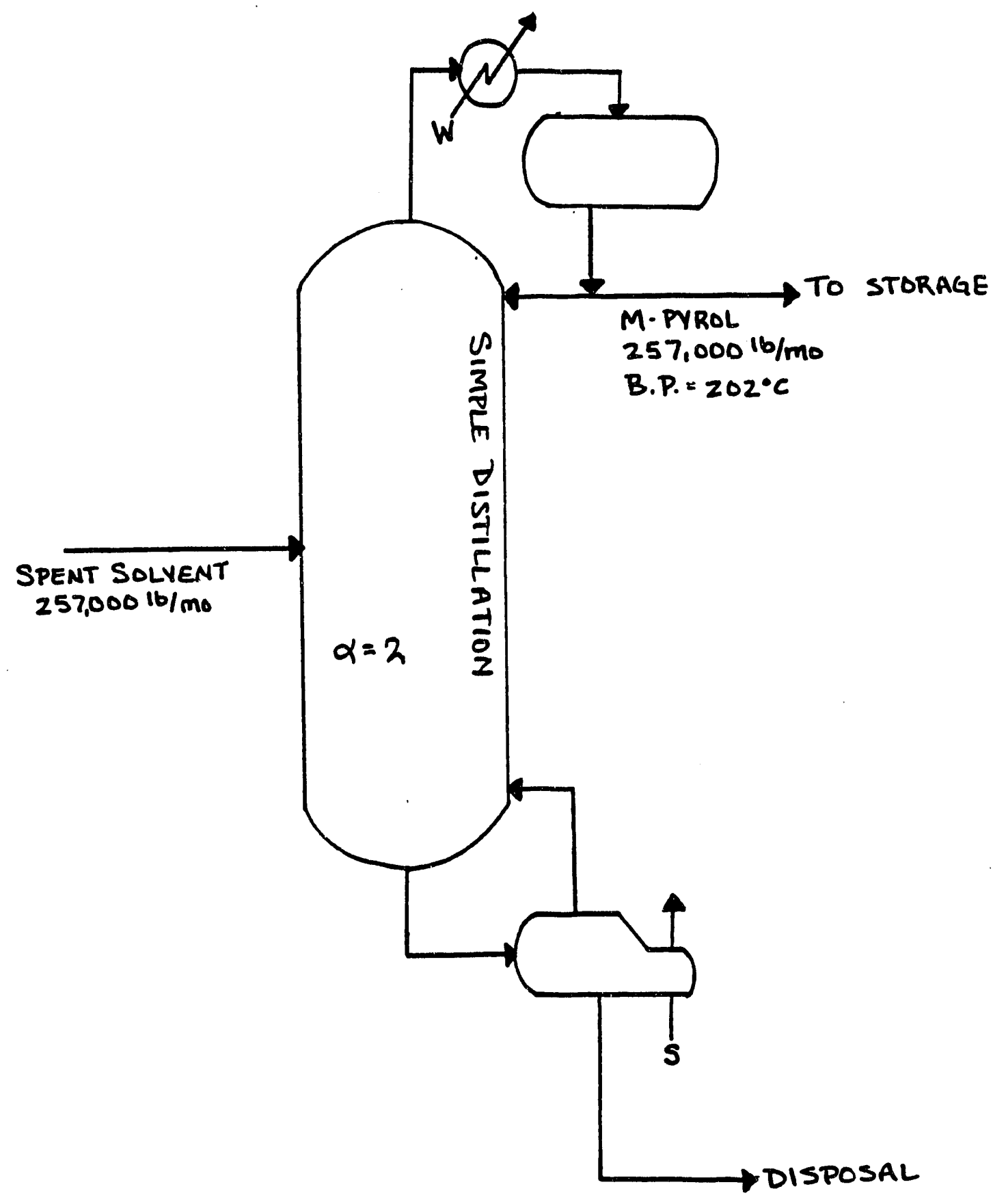

SPENT SOLYENT $\frac{\text { SIMPLE }}{\text { DISTILLATION }}$ M-PYRDL + CONTAMINANTS 
The purpose of this project was to discuss the economics of recovering MPYROL from the spent paint solvent. The process was designed by Dr. Berg for this particular solvent. The spent solvent is produced at five Air Force Bases around the country (from Delaware to Texas). Each base contaminates approximately 30,000 gal. of solvent a year. The scope of this study is to determine if it is more economical to build one plant at Tinker Air Force Base in Oklahoma and have the over four bases ship their spent solvent for recovery or If each base should build its own plant to recover the solvent they contaminate. The spent solvent is free since it is contaminated and unusable. After recovery of the M-PYROL it is sold as the product.

The separation of M-PYROL solvent from its paint contaminates is relatively simple. It has a boiling point of $202^{\circ} \mathrm{C}$ and the boiling point of the paint contaminants is much higher. The relative volatility of the mixture is 2 , which allows for simple distlllation. Assuming a 99\% purity of overhead and bottoms, 13 theoretical plates are required. This amounts to 18 actual plates assuming an efficiency of $75 \%$.

For a product capacity of 257,000 pounds per month of M-PYROL, a spent solvent feed of the same amount is required. The spent solvent costs nothing. M-PYROL is sold as product at $\$ 1.59$ per pound. The difference between the two options is basically the cost of shipping the spent solvents to one plant. Either option will require the same size plant, therefore capitol investment will be identical. Option A will require that the plait be run for five months per year to recover a total of 150,000 gallons of solvent; while option B will only run for one month out of the year to recover only the 30,000 gallons of the solvent used at that base. Option A provides a net profit of 
$\$ 987,000$ per year while option B yields a $\$ 182,000$ profit per year. Option A gives a rate of return on investment of $230 \%$ and a payout time of only 5.2 months. Option B produces only a $42 \%$ rate of return on investment and has a payout time of 2.4 years. Obviously, option $A$ is the better plan as it will pay for itself faster. 


\section{SUMMMARY AND COMPARISONS OF CALCULATIONS}

\begin{tabular}{|c|c|c|}
\hline & $\begin{array}{r}\text { OPTION A } \\
1 \text { plant } \\
\text { run } 5 \text { months } \\
\end{array}$ & $\begin{array}{r}\text { OPTION B } \\
1 \text { plant per site } \\
\text { run } 1 \text { month } \\
\end{array}$ \\
\hline MONTHIY CAPACITY & $257,000 \mathrm{lb} / \mathrm{mo}$ & $257,000 \mathrm{lb} / \mathrm{mo}$ \\
\hline TOTAL REVENUE & $\$ 2,043,000 / y r$ & $\$ 407,000 / y \mathbf{r}$ \\
\hline \multicolumn{3}{|l|}{ CAPITAL COST } \\
\hline TOTAL & $\$ 430,000$ & $\$ 430,000$ \\
\hline 10\% DEPRECIATION & $\$ 43,000 / \overline{y r}$ & $\$ 43,000 / y x$ \\
\hline 3\% PROPERTY TAX & $\$ 12,900 / y x$ & $\$ 12,900 / \mathbf{y r}$ \\
\hline OPERATUNG COST & $\$ 513,900 / y \mathbf{r}$ & $\$ 79,400 / y x$ \\
\hline GROSS PROFIT & $\$ 1,473,200 / y r$ & $\$ 271,700 / y x$ \\
\hline NET PROFIT (33\% INCOME TAX) & $\$ 987,000 / y \mathbf{r}$ & $\$ 182,000 / y r$ \\
\hline RATE OF RETURN ON INVESTMENT & $230 \%$ & $42 \%$ \\
\hline PAYOUT TIME & 5.2 months & 2.4 years \\
\hline
\end{tabular}


Columns, pumps, column internals, reflux tank, heat exchangers \& controls $\$ 100,000$

Bidding, designs \& simulation $\$ 100,000$

Assembling $\$ \mathbf{5 0 , 0 0 0}$

Putting on skids $\$ 20,000$

Storage tanks

$\$ 15,000$

Piping \& Electrical installation $\$ \mathbf{8 0 , 0 0 0}$

Contigencey $\$ 65,000$

TOTAL INVESTMENT $\$ 430,000$ 


\section{OPERATING COST}

OPERATING IABOR

SUPERVISION

MANTENANCE \& REPAIRS

STEAM COST

SLUDGE RECOVERY \& DISPOSAL

MOVING EXPENSES

TOTAT OPERATING COST
OPTION A

1 plant 1 plant per site

run 5 months

$\$ 336,000 / y \mathbf{r}$

$\$ 10,500 / \mathrm{yr}$

$\$ 15,000 / y x$

$\$ 2,350 /$ yr run 1 month

$\$ 53,800 /$ yr

$\$ 2,100 / y r$

$\$ 3,000 / y x$

$\$ 470 / y x$

$\$ 100,000 / y x$ $\$ 20,000 / y x$

$\$ 50,000 / y x$

o

$\$ 513,900 / y x$ 
ECONOMIC Calculations

Plant Capacity $\Rightarrow 257,000 \mathrm{lb} /$ month M-PYROLproduced Prices $\Rightarrow$ spent solvent

$$
\text { M-PYROL } \$ 1.59 / \mathrm{lb} \text {. }
$$

- (A) One plant (spent solvents shipped from other sites)

(B) Plant at each site (analysis for one plant)

* total revenlie

(A) M-PYROL

\begin{tabular}{r|c|c|c|}
$257,000 l b$ & $\$ 1.59$ & 5 mo.
\end{tabular}

$\$ 2,043,000 / y r$.

(B) M-PYROL

$$
\begin{array}{c|c|c}
257.000 \mathrm{lb} & \$ 1.59 & 1 \mathrm{mo} . \\
\hline \text { mo } & \mathrm{lb} & \mathrm{yr} .
\end{array}
$$

$\$ 407,000 / y r$.

*FEED COST

$(A) \&(B)$

D-10 
* Capital cost

(A) \& (B) for one plant (estimated by Richard Rall, Koch Engr. (o., Wichita, KS \& Dr. Berg)

Columns, pumps, column internals, reflux tank, heat exchangers, \&controls $\$ 100,000$

Bidding, designs simulation

Assembling

Putting on skids

storage tanks

Piping Electrical Installation

Contingency

Total Investment

*DEPRECIATION

(A) \& (B) $10 \%$ per year

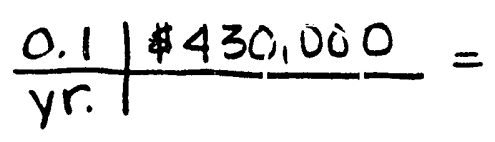

* PROPERTY TAX

$(A)$ \& $(B) \quad 3 \%$ per year

$$
\begin{array}{l|l}
0.03 & \$ 430,000 \\
\hline y r & =
\end{array}
$$

100,000

50,000

20,000

15,000

80,000

65,000

$\$ 430,000$

$\$ 43,000 / y r$.

\#12,900/4r.

D-11 
* OPERATING COST

(A) -running 5 months per year

Operating Labor:

$$
\begin{array}{c|c|c|c|c}
\$ 40 & Z_{\text {people }} & 168 h r & 4 \text { wok } & 5 \mathrm{mo} \\
\hline h_{r} & \text { wk } & \text { mo } &
\end{array}
$$

Supervision:

$$
\begin{array}{c|c|c}
850 & 42 \mathrm{hr} & 5 \mathrm{mo} . \\
\hline \mathrm{m} & \text { mo. } & \mathrm{yr} .
\end{array}
$$

Maintenance \& Repairs:

$$
\frac{3000}{m o} \frac{5 \mathrm{mo}}{\mathrm{yr}}=
$$

Steam Cost:

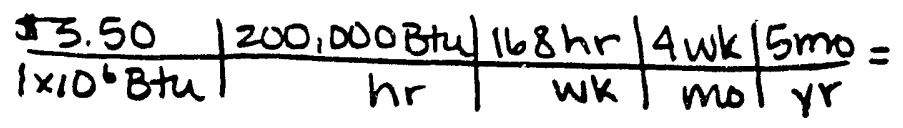

Sludge Recovery \& Disposal

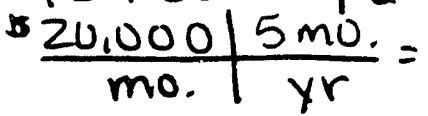

Moving Expenses

Total Operating Costs

(B) -running I month per year

Operating Labor:

$$
\begin{array}{c|c|c|c|c}
\$ 40 & 2 \text { people } & 168 h r & 4 w k & 1 m o \\
\hline r & & \text { mk } & \text { mo } & y r
\end{array}
$$

Supervision:

\begin{tabular}{c|c|c}
150 & $42 \mathrm{hr}$ & $1 \mathrm{mo}$ \\
\hline $\mathrm{hr}$ & $\mathrm{mo}$ & $\mathrm{yr}$
\end{tabular}

Maintenance \&Repairs:

$\$ \frac{3000}{\text { mo }} \mid \frac{\text { mo }}{Y r}=$
$\$ 336,000 / y r$

$\$ 10,500 / y r$

$\$ 15,000 / y r$.

$2,350 / 4 r$.

$100,000 / y r$

$50,000 / y r$.

$\$ 513,900 / \mathrm{yr}$

$\$ 53,800 / y r$

$\$ 2100 / y r$

$\$ 3000 /$ yr

D.12 
* Operating costs (cont.)

(B) (cont.)

Steam Cost:

\begin{tabular}{c|c|c|c|c}
$\$ 3.50$ & $200,000 \mathrm{Btu}$ & $168 \mathrm{hr}$ & $4 \mathrm{wk}$ & $\mathrm{Imo}$ \\
\hline $1 \times 10^{6} \mathrm{Bth}$ & $\mathrm{hr}$ & $\mathrm{wk}$ & $\mathrm{mo}$ & $\mathrm{yr}$
\end{tabular}

Sludge Becovery Disposal

\begin{tabular}{c|c|c|}
20,000 & mo. \\
\hline mo. & yr.
\end{tabular}

Total Operating Costs

$\$ 79,400 / 4 r$

* GROSS PROFIT

GP $=$ Revenue - Feed - Depreciation - Tax-Operatine,

(A) $2,043,000-0-43,000-12,900-513,900=\$ 1,473,200 / \mathrm{m}$

(B) $407,000-0-43,000-12,900-79,400=\quad 271,700 / \mathrm{yr}$

*NET PROFIT

$33 \%$ Income Tax

Net Profit $=0.67 \times$ Gross Procluct
(A) $\frac{0.67}{\frac{11,473,200}{y r}}=$
\& $987,000 / y r$.

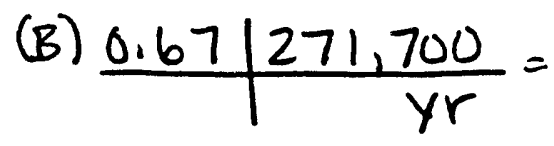
$\$ 182,000 / y r$. 
* rate of return on investment $R R O 1=\frac{\text { Net profit }}{\text { Capital Cost }} \times 100$

(A) $\$ \frac{987,000}{430,000} \mid 100=$

$230 \%$

(B) $\frac{182,000}{436,000} 100=$

$42 \%$

* PAYOUT TIME

$$
\text { PT }=\frac{\text { Capital Cost }}{\text { Net profit }}
$$

(A) $\frac{\$ 330,000}{987,000 / y r}=0.44 y r=$

$5.2 \mathrm{mo}$.

(B) $\frac{\$ 30,000}{\$ 182,000 / y r}=$

$2.4 \mathrm{yr}$

D.14 


\section{Appendix E}

5 Plant to 1 Plant Paint Solvent Recovery of TURCO T-5668 Solvent 
E-2 
Chemical Process Industries

Final Project

5 plant to 1 plant

Paint Solvent Recovery of

TURCO T-5668 solvent

Written by:

scott Waltari

E-3 
Due to the increasing taboo against chlorinated solvents, the government has decided to limit the use of said solvents in paint removal at their major air force bases. One possible solvent considered to replace the chlorinated solvents is TURCO T-5668. This solvent consists of $22 \%$ ethanol amine, $60 \% \mathrm{~N}$-methyl pyrrolidinone (M-Pyrol), and $10 \%$ hydrogenated naphthenes.

The solvent will be recovered by using a continuous distillation process. The recovery procedure is as follows:

1. Filter out the paint chips.

2. Rectify the liquid phase in a batch column. Distill off: the ethanolamine at $170^{\circ} \mathrm{C}$ and $99 \%$ purity.

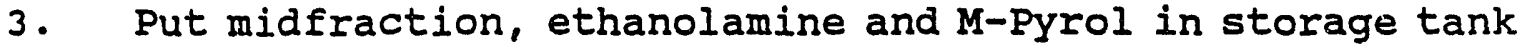
for recycle.

4. Distill off the M-Pyrol at $202^{\circ} \mathrm{C}$.

5. Put midfraction, M-Pyrol and naphthenes in storage tank for recycle.

6. Distill off naphthenes at $170^{\circ} \mathrm{C}$ and reduced pressure.

7. Empty stillpot, send to waste.

8. Refill stillpot, with new charge plus both midfraction recycle streams from previous run.

Batch operation and midfraction recovery takes about $50 \%$ more time.

Two plant styles are being considered for use in the paint recovery. One style consists of 5 bases sending their used solvent to one central location where one plant will recover all of the solvent. The other style consists of 1 plant at each base which will treat the used solvent of only one base. Plants involved with each style will be the same size, only the operation time will change.

The initial investment for a plant that can handle a capacity of 30,000 gallons of solvent per month totals about $\$ 465,000$. This investment is the same for both styles. Table 1 gives a breakdown of the expenses. 
Table 1, INVESTMENT

\begin{tabular}{|l|c|}
\hline $\begin{array}{l}\text { Column, pumps, column internals, reflux tank, heat } \\
\text { exchangers, \& controls }\end{array}$ & $\$ 100,000$ \\
\hline Bidding, designs, \& simulation & 100,000 \\
\hline Assembling & 50,000 \\
\hline Putting on skids & 20,000 \\
\hline Storage tanks & 30,000 \\
\hline Piping \& electrical installation & 80,000 \\
\hline Contingency & 65,000 \\
\hline ToTAL INVESTMENT & $\$ 465,000$ \\
\hline
\end{tabular}

Annual expenses for each style will change due to varying operation times. operating time for 1 central plant will be approximately 5 months where as the operating time for 5 plants will be approximately 1 month. Table 2 gives a breakdown of the annual expenses for each style.

Table 2, Expenses

\begin{tabular}{||l|r|r||}
\hline & 1 Plant & 5 Plants \\
\hline Operating Labor: $\$ 40 / \mathrm{hr} * 2$ people & $\$ 460,800$ & $\$ 86,400$ \\
\hline Supervision: $\$ 50 / \mathrm{hr} * 42 \mathrm{hr} / \mathrm{mo}$ & 16,800 & 3,200 \\
\hline Maintenance \& Repairs & 15,000 & 3,000 \\
\hline Steam Cost: 200,000 BTU/hr*\$3.50 M & 3,760 & 820 \\
\hline Sludge Recovery \& Disposal & 100,000 & 20,000 \\
\hline Moving Expense & 50,000 & 0 \\
\hline Depreciation: 10\% per year & 46,500 & 46,500 \\
\hline Property Taxes @ 3\% & 14,000 & 14,000 \\
\hline TOTAL EXPENSES & $\$ 706,860$ & $\$ 173,920$ \\
\hline
\end{tabular}

Revenue for the project will be made by reselling the recovered paint solvent at market prices. Cost of raw materials is considered zero due to its status as waste. The revenue generated 
from the solvent is found in Table 3. Also included in Table 3 are net income, return on investment, and payout time.

Table 3, REVENUE

\begin{tabular}{|l|r|r|}
\hline Ethanolamine: $\$ 5.0445 / \mathrm{gal}$ & $\$ 166,500$ & $\$ 33,300$ \\
\hline M-Byrol: $\$ 14.535 / \mathrm{gal}$ & $1,308,150$ & 244,700 \\
\hline Hydrogenated Naphthenes: $\$ 1.71 / \mathrm{gal}$ & 25,650 & 5,130 \\
\hline TOTAI REVENUE & $\$ 1,500,300$ & $\$ 283,130$ \\
\hline NET INCOME & $\$ 793,400$ & $\$ 109,210$ \\
\hline Return on Investment: Income/Invest & $171 \%$ & $23 \%$ \\
\hline Payout Time: 1 year/Return of Invest & 7 mo & 4.3 yrs \\
\hline
\end{tabular}

Overall both projects appear to be quite feasible. The most economical process would be to ship the solvent to one centralized location and process it there. If fees for shipping waste rise enormously, the 5 plant method would become more feasible. The 5 plant method would also become more feasible if the plant was scaled down. 


\section{Appendix F}

Solvent Components Boiling Temperatures 


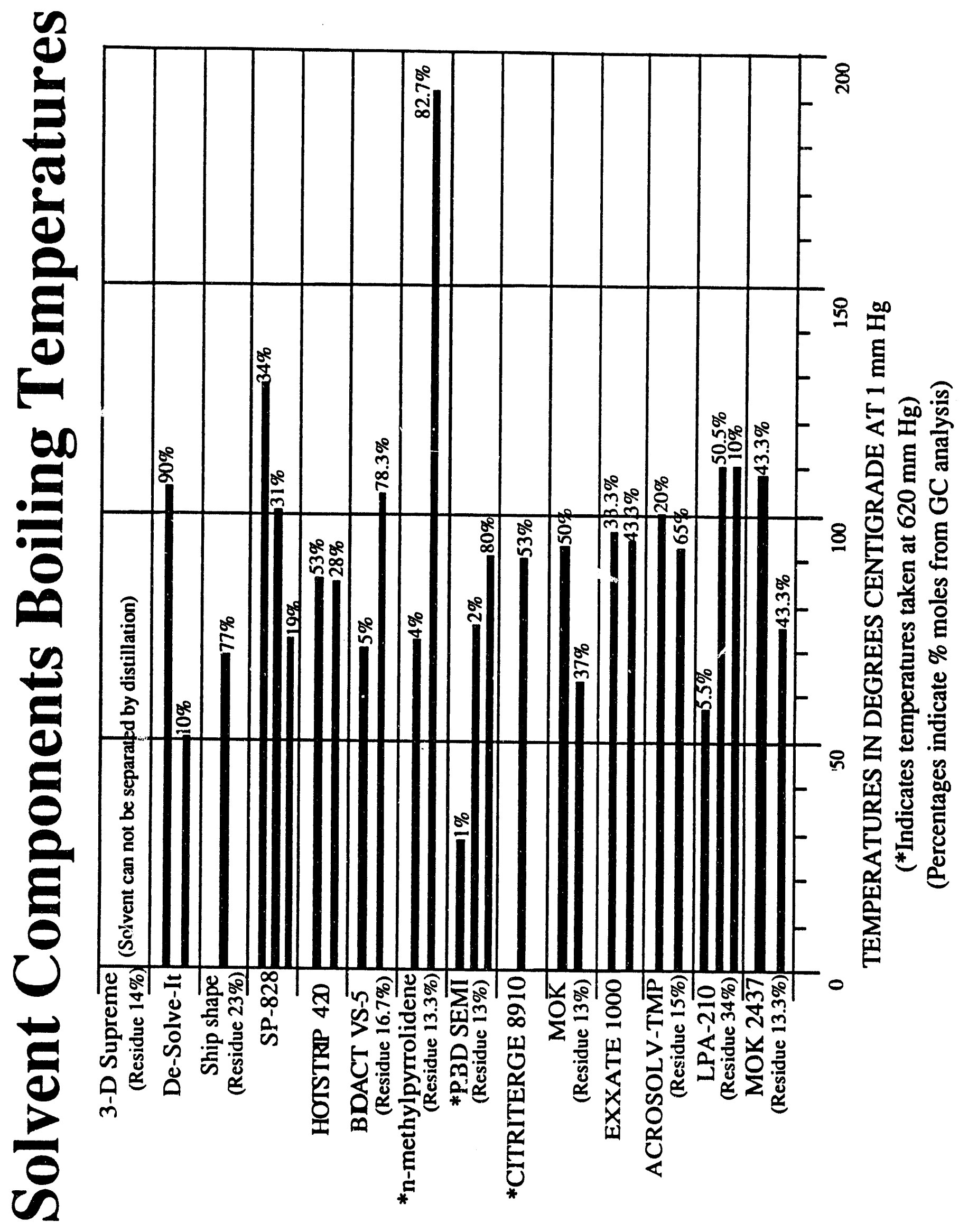



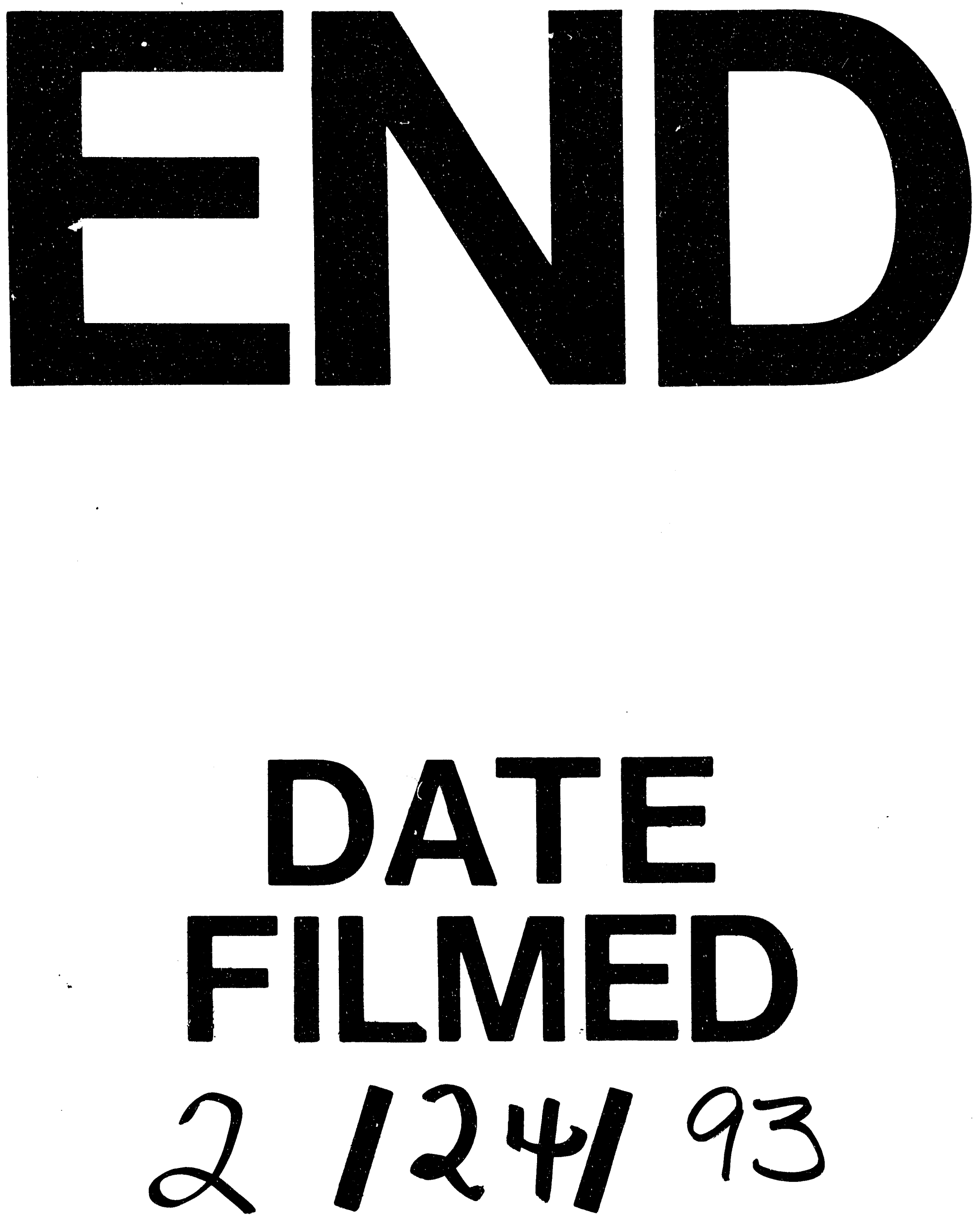

93 
